Cochrane Database of Systematic Reviews

\title{
Renal denervation for resistant hypertension (Review)
}

Coppolino G, Pisano A, Rivoli L, Bolignano D

Coppolino G, Pisano A, Rivoli L, Bolignano D.

Renal denervation for resistant hypertension.

Cochrane Database of Systematic Reviews 2017, Issue 2. Art. No.: CD011499.

DOI: 10.1002/14651858.CD011499.pub2.

www.cochranelibrary.com 
TABLE OF CONTENTS

HEADER 1

ABSTRACT

PLAIN LANGUAGE SUMMARY

SUMMARY OF FINDINGS

BACKGROUND

OBJECTIVES

METHODS

RESULTS

Figure 1.

Figure 2.

Figure 3.

DISCUSSION

AUTHORS' CONCLUSIONS

ACKNOWLEDGEMENTS

REFERENCES

CHARACTERISTICS OF STUDIES

DATA AND ANALYSES

Analysis 1.1. Comparison 1 Renal denervation vs. sham/standard therapy, Outcome 1 Myocardial infarction.

Analysis 1.2. Comparison 1 Renal denervation vs. sham/standard therapy, Outcome 2 ischaemic stroke.

Analysis 1.3. Comparison 1 Renal denervation vs. sham/standard therapy, Outcome 3 unstable angina.

Analysis 1.4. Comparison 1 Renal denervation vs. sham/standard therapy, Outcome 4 systolic 24-hour ABPM.

Analysis 1.5. Comparison 1 Renal denervation vs. sham/standard therapy, Outcome 5 diastolic 24-hour ABPM.

Analysis 1.6. Comparison 1 Renal denervation vs. sham/standard therapy, Outcome 6 systolic office BP.

Analysis 1.7. Comparison 1 Renal denervation vs. sham/standard therapy, Outcome 7 diastolic office BP.

Analysis 1.8. Comparison 1 Renal denervation vs. sham/standard therapy, Outcome 8 serum creatinine.

Analysis 1.9. Comparison 1 Renal denervation vs. sham/standard therapy, Outcome 9 eGFR/creatinine clearance.

Analysis 1.10. Comparison 1 Renal denervation vs. sham/standard therapy, Outcome 10 bradycardia.

Analysis 1.11. Comparison 1 Renal denervation vs. sham/standard therapy, Outcome 11 femoral artery pseudoaneurysm. ....

Analysis 1.12. Comparison 1 Renal denervation vs. sham/standard therapy, Outcome 12 flank pain.

Analysis 1.13. Comparison 1 Renal denervation vs. sham/standard therapy, Outcome 13 hypotensive episodes. .....................

Analysis 1.14. Comparison 1 Renal denervation vs. sham/standard therapy, Outcome 14 hypertensive crisis. ..........................

Analysis 1.15. Comparison 1 Renal denervation vs. sham/standard therapy, Outcome 15 hyperkalemia.

APPENDICES

CONTRIBUTIONS OF AUTHORS

DECLARATIONS OF INTEREST

SOURCES OF SUPPORT

DIFFERENCES BETWEEN PROTOCOL AND REVIEW

INDEX TERMS 
[Intervention Review]

\section{Renal denervation for resistant hypertension}

Giuseppe Coppolino ${ }^{1}$, Anna Pisano ${ }^{2}$, Laura Rivoli3 ${ }^{3}$, Davide Bolignano 2

1Nephrology and Dialysis Unit, "Pugliese-Ciaccio" General Hospital, Catanzaro, Italy. 2Institute of Clinical Physiology, CNR - Italian National Council of Research, Reggio Calabria, Italy. ${ }^{3}$ Department of Medical and Surgical Sciences, Nephrology and Dialysis Unit, University "Magna Graecia", Catanzaro, Italy

Contact address: Davide Bolignano, Institute of Clinical Physiology, CNR - Italian National Council of Research, CNR-IFC Via Vallone Petrara c/o Ospedali Riuniti, Reggio Calabria, 89100, Italy. davide.bolignano@gmail.com.

Editorial group: Cochrane Hypertension Group.

Publication status and date: New, published in Issue 2, 2017.

Citation: Coppolino G, Pisano A, Rivoli L, Bolignano D. Renal denervation for resistant hypertension. Cochrane Database of Systematic Reviews 2017, Issue 2. Art. No.: CD011499. DOI: 10.1002/14651858.CD011499.pub2.

Copyright @ 2017 The Cochrane Collaboration. Published by John Wiley \& Sons, Ltd.

\section{A B S T R A C T}

\section{Background}

Resistant hypertension is highly prevalent among the general hypertensive population and the clinical management of this condition remains problematic. Different approaches, including a more intensified antihypertensive therapy, lifestyle modifications, or both, have largely failed to improve patients' outcomes and to reduce cardiovascular and renal risk. As renal sympathetic hyperactivity is a major driver of resistant hypertension, renal sympathetic ablation (renal denervation) has been recently proposed as a possible therapeutic alternative to treat this condition.

\section{Objectives}

We sought to evaluate the short- and long-term effects of renal denervation in individuals with resistant hypertension on clinical end points, including fatal and non-fatal cardiovascular events, all-cause mortality, hospital admissions, quality of life, blood pressure control, left ventricular hypertrophy, cardiovascular and metabolic profile, and kidney function, as well as the potential adverse events related to the procedure.

\section{Search methods}

We searched the following databases to 17 February 2016 using relevant search terms: the Cochrane Hypertension Group Specialised Register, the Cochrane Central Register of Controlled Trials (CENTRAL), MEDLINE, EMBASE and ClinicalTrials.gov

\section{Selection criteria}

We considered randomised controlled trials (RCTs) that compared renal denervation to standard therapy or sham procedure to treat resistant hypertension, without language restriction.

\section{Data collection and analysis}

Two authors independently extracted data and assessed study risks of bias. We summarised treatment effects on available clinical outcomes and adverse events using random-effects meta-analyses. We assessed heterogeneity in estimated treatment effects using Chi ${ }^{2}$ and $\mathrm{I}^{2}$ statistics. We calculated summary treatment estimates as a mean difference (MD) or standardised mean difference (SMD) for continuous outcomes, and a risk ratio (RR) for dichotomous outcomes, together with their 95\% confidence intervals (CI).

\section{Main results}

We found 12 eligible studies (1149 participants). In four studies, renal denervation was compared to sham procedure; one study compared a proximal ablation to a complete renal artery denervation; in the remaining, renal denervation was tested against standard or intensified antihypertensive therapy. 
None of the included trials was designed to look at hard clinical end points as primary outcomes.

When compared to control, there was low quality evidence that renal denervation did not reduce the risk of myocardial infarction (4 studies, 742 participants; RR $1.31,95 \% \mathrm{Cl} 0.45$ to 3.84 ), ischaemic stroke (4 studies, 823 participants; RR 1.15 , $95 \% \mathrm{Cl} 0.36$ to 3.72 ), or unstable angina ( 2 studies, 201 participants; RR $0.63,95 \% \mathrm{Cl} 0.08$ to 5.06 ), and moderate quality evidence that it had no effect on 24 -hour ambulatory blood pressure monitoring (ABPM) systolic BP ( 5 studies, 797 participants; $\mathrm{MD} 0.28 \mathrm{mmHg}, 95 \% \mathrm{Cl}-3.74$ to 4.29 ), diastolic BP (4 studies, 756 participants; MD $0.93 \mathrm{mmHg}, 95 \% \mathrm{Cl}-4.50$ to 6.36 ), office measured systolic $\mathrm{BP}$ ( 6 studies, 886 participants; $\mathrm{MD}-4.08 \mathrm{mmHg}, 95 \% \mathrm{Cl}-15.26$ to 7.11), or diastolic BP (5 studies, 845 participants; $\mathrm{MD}-1.30 \mathrm{mmHg}, 95 \% \mathrm{Cl}-7.30$ to 4.69 ). Furthermore, low quality evidence suggested that this procedure produced no effect on either serum creatinine ( 3 studies, 736 participants, MD $0.01 \mathrm{mg} / \mathrm{dL} ; 95 \% \mathrm{Cl}-0.12$ to 0.14 ), estimated glomerular filtration rate (eGFR), or creatinine clearance (4 studies, 837 participants; $\mathrm{MD}-2.09 \mathrm{~mL} / \mathrm{min}, 95 \% \mathrm{Cl}-8.12$ to 3.95 ). Based on lowquality evidence, renal denervation significantly increased bradycardia episodes compared to control (3 studies, 220 participants; RR 6.63, $95 \% \mathrm{Cl} 1.19$ to 36.84 ), while the risk of other adverse events was comparable or not assessable.

Data were sparse or absent for all cause mortality, hospitalisation, fatal cardiovascular events, quality of life, atrial fibrillation episodes, left ventricular hypertrophy, sleep apnoea severity, need for renal replacement therapy, and metabolic profile.

The quality of the evidence was low for cardiovascular outcomes and adverse events and moderate for lack of effect on blood pressure and renal function.

\section{Authors' conclusions}

In patients with resistant hypertension, there is low quality evidence that renal denervation does not change major cardiovascular events, and renal function. There was moderate quality evidence that it does not change blood pressure and and low quality evidence that it caused an increaseof bradycardia episodes. Future trials measuring patient-centred instead of surrogate outcomes, with longer follow-up periods, larger sample size and more standardized procedural methods are necessary to clarify the utility of this procedure in this population.

\section{PLAIN LANGUAGE SUMMARY}

\section{Renal denervation for improving outcomes in individuals with resistant hypertension}

\section{Review question}

What are the benefits and harms of renal denervation in individuals with resistant hypertension, on clinically important outcomes, including cardiovascular morbidity and mortality, blood pressure control, kidney function, and the occurrence of various adverse events.

\section{Background}

Resistant hypertension is a condition characterised by persistently high blood pressure levels in spite of multiple blood pressure lowering (antihypertensive) medications, given at maximum doses. The estimated prevalence of this condition ranges from $10 \%$ to $20 \%$ of the general hypertensive population. Despite therapeutic and lifestyle approaches that have been proposed, the management of individuals with resistant hypertension remains difficult, with a high incidence of poor outcomes and adverse cardiovascular events. Recently, renal sympathetic denervation, a procedure consisting of destroying renal nerves with a radiofrequency catheter inserted through a minimally invasive incision, has emerged as a possible therapeutic alternative to treat this condition.

\section{Study characteristics}

Twelve studies of variable quality were identified that included a total of 1149 participants. There was high heterogeneity among studies for design, methods, and blinding of investigators. Most of the studies assessed the impact of renal denervation on surrogate (e.g. blood pressure control), rather than patient-centred outcomes (e.g. mortality or quality of life).

\section{Key results}

Overall, there was no evidence of benefits of renal denervation over standard treatment on cardiovascular morbidity and mortality. Similarly, renal denervation had no tangible effects on blood pressure control and renal function. However, it was associated with an increased risk of episodes of bradycardia (very slow heart rate).

\section{Quality of the evidence}

The quality of the evidence was low for cardiovascular morbidity and adverse events and moderate for lack of effect on blood pressure and renal function. The evidence is current to 17 February 2016.

\section{Conclusions}

Current evidence is inconclusive to support the use of renal denervation to improve cardiovascular and renal risk and blood pressure control in patients with resistant hypertension. Future studies targeting patient-centred outcomes, with longer duration and larger number of participants are needed to identify whether individuals can benefit from this procedure. 


\begin{tabular}{|c|c|c|c|c|c|}
\hline \multicolumn{6}{|c|}{$\begin{array}{l}\text { S U M M A R Y O F F I N D I N G S } \\
\text { Summary of findings for the main comparison. }\end{array}$} \\
\hline \multicolumn{6}{|c|}{ Renal denervation versus sham denervation or standard treatment } \\
\hline \multicolumn{6}{|c|}{$\begin{array}{l}\text { Patient or population: people with resistant hypertension } \\
\text { Setting: Outpatient } \\
\text { Intervention: renal denervation } \\
\text { Comparison: sham denervation or standard treatment }\end{array}$} \\
\hline \multirow[t]{3}{*}{ Outcomes } & \multicolumn{2}{|c|}{ Illustrative comparative risks* $(95 \% \mathrm{CI})$} & \multirow{3}{*}{$\begin{array}{l}\text { Effect estimate } \\
(95 \% \mathrm{Cl})\end{array}$} & \multirow{3}{*}{$\begin{array}{l}\text { No of Participants } \\
\text { (studies) }\end{array}$} & \multirow{3}{*}{$\begin{array}{l}\text { Quality of the evi- } \\
\text { dence } \\
\text { (GRADE) }\end{array}$} \\
\hline & Assumed risk & $\begin{array}{l}\text { Corresponding } \\
\text { risk }\end{array}$ & & & \\
\hline & $\begin{array}{l}\text { Sham denerva- } \\
\text { tion/ } \\
\text { Standard treat- } \\
\text { ment }\end{array}$ & Renal denervation & & & \\
\hline myocardial infarction & 14 per 1000 & $\begin{array}{l}18 \text { per } 1000 \text { (6 to } \\
54)\end{array}$ & RR 1.31 (0.45 to 3.84$)$ & $\begin{array}{l}742 \\
\text { (4 studies) }\end{array}$ & $\begin{array}{l}\oplus \oplus \ominus \ominus \\
\operatorname{low} 1,2\end{array}$ \\
\hline ischaemic stroke & 12 per 1000 & $\begin{array}{l}14 \text { per } 1000 \text { (4 to } \\
45)\end{array}$ & RR 1.15 (0.36 to 3.72 ) & $\begin{array}{l}823 \\
\text { (4 studies) }\end{array}$ & $\begin{array}{l}\oplus \oplus \ominus \ominus \\
\text { low } 1,2\end{array}$ \\
\hline unstable angina & 20 per 1000 & $\begin{array}{l}12 \text { per } 1000 \text { ( } 2 \text { to } \\
101 \text { ) }\end{array}$ & RR 0.63 (0.08 to 5.06$)$ & $\begin{array}{l}201 \\
\text { (2 studies) }\end{array}$ & $\begin{array}{l}\oplus \oplus \ominus \ominus \\
\operatorname{low} 1,2\end{array}$ \\
\hline systolic 24-hour ABPM (mmHg) & - & - & MD 0.28 (-3.74 to 4.29$)$ & $\begin{array}{l}797 \\
\text { (5 studies) }\end{array}$ & $\begin{array}{l}\oplus \oplus \oplus \ominus \\
\text { moderate } 1\end{array}$ \\
\hline diastolic 24-hour ABPM (mmHg) & - & - & MD $0.93(-4.50$ to 6.36$)$ & $\begin{array}{l}756 \\
\text { (4 studies) }\end{array}$ & $\begin{array}{l}\oplus \oplus \oplus \ominus \\
\text { moderate } 1\end{array}$ \\
\hline systolic office BP (mmHg) & - & - & MD $-4.08(-15.26$ to 7.11$)$ & $\begin{array}{l}886 \\
\text { (6 studies) }\end{array}$ & $\begin{array}{l}\oplus \oplus \oplus \ominus \\
\text { moderate1 }\end{array}$ \\
\hline diastolic office BP (mmHg) & - & - & MD $-1.30(-7.30$ to 4.69$)$ & $\begin{array}{l}845 \\
\text { (5 studies) }\end{array}$ & $\oplus \oplus \oplus \ominus$ \\
\hline
\end{tabular}

Comparison: sham denervation or standard treatment 
*The assumed risk is the observed risk in the reference (control) group. The corresponding risk (and its $95 \%$ confidence interval) is based on the assumed risk in the comparison group and the relative effect of the intervention (and its $95 \% \mathrm{CI}$ ).

GRADE Working Group grades of evidence

High quality: Further research is very unlikely to change our confidence in the estimate of effect.

Moderate quality: Further research is likely to have an important impact on our confidence in the estimate of effect and may change the estimate.

Low quality: Further research is very likely to have an important impact on our confidence in the estimate of effect and is likely to change the estimate.

Very low quality: We are very uncertain about the estimate.

\section{Legend}

ABPM: ambulatory blood pressure monitoring; BP: blood pressure; Cl: Confidence interval; CV: cardiovascular; NA: information not available (data sparse or absent); eGFR:

estimated glomerular filtration rate; MD: mean difference; RR: Risk Ratio.

1. Wide confidence intervals.

2. Only reported by less than half of the studies. 


\section{B A C K G R O U N D}

\section{Description of the condition}

Resistant or refractory hypertension is characterised by blood pressure levels persistently above target, in spite of the concurrent use of three antihypertensive agents of different classes at besttolerated doses, including a diuretic (Calhoun 2008). Data from cross-sectional and hypertension outcome studies suggest that this condition is not infrequent, with an estimated prevalence of $10 \%$ to $20 \%$ in the general hypertensive population (Myat 2012). Individuals with resistant hypertension are $50 \%$ more likely to experience poor outcomes and adverse cardiovascular events than those with controlled hypertension (Judd 2014). The lack of efficacy of multiple interventions in addition to pharmacological therapy, including dietary and lifestyle modifications, emphasises the importance of finding new effective and safe treatments for treating this condition.

\section{Description of the intervention}

Renal sympathetic denervation comprises the ablation of renal afferent and efferent nerves by a radiofrequency catheter through a minimally invasive, percutaneous intervention performed via femoral access. The thermal increase generated by the application of low-dose radiofrequency energy is effective in disrupting large portions of nervous fibres located within the adventitia of the renal artery.

\section{How the intervention might work}

Sympathetic hyperactivity has long been acknowledged as a major player in the genesis of resistant hypertension (Huan 2013). In studies conducted in the eighties, surgical sympathectomy was effective in some individuals in lowering blood pressure and symptoms associated with severe hypertension. However, this procedure is no longer used because of considerable side effects (Leong 2014). As with sympathectomy, renal denervation might improve blood pressure control by reducing abnormal renal adrenergic nerve activity. Furthermore, since other conditions, such as congestive heart failure, atrial fibrillation, sleep breathing disorders, and diabetes mellitus are all associated with an overactive sympathetic drive, this procedure might result in pleiotropic benefits, including improvements in glycaemic levels, sleep apnoea, arrhythmias, and oxidative stress (Witkowski 2011). Of note, in spontaneously hypertensive rats, renal denervation was able to ameliorate metabolic control and to prevent hypertensive stroke and brain injury, in addition to controlling blood pressure (Nakagawa 2013a; Nakagawa 2013b).

\section{Why it is important to do this review}

As shown in a recent meta-analysis, renal denervation reduced mean blood pressure at six months in individuals with persistent hypertension; intra-procedural complications, including renal artery dissection and femoral pseudoaneurysms were rare (Davis 2013). Unfortunately, data were mostly derived from observational, uncontrolled studies with limited follow-up, small sample sizes, and high heterogeneity in blood pressure measurement. Whether the benefits of renal denervation on blood pressure control are maintained in the long term, and particularly, whether this procedure might impact hard outcomes, such as mortality and cardiovascular events, remain unknown at this time. New evidence, based on larger, randomised controlled trials (RCTs), is now accruing, and long-term data on the efficacy of renal denervation on surrogate and hard end points in the long term are becoming available. Therefore, an updated assessment of the efficacy and safety profile of this procedure is mandatory to define whether the benefits of implementing renal denervation in the clinical management of individuals with resistant hypertension outweigh the harms.

\section{O B JECTIVES}

To evaluate the short- and long-term effects of renal sympathetic denervation in individuals with resistant hypertension on:

- patient-centred end points, including cardiovascular morbidity and mortality, all-cause mortality, hospital admissions, and quality of life;

- blood pressure control;

- cardiovascular and metabolic profile;

- kidney function;

- adverse events, including but not limited to bradycardia, hypotension episodes, femoral artery pseudoaneurysm, and renal artery dissection.

\section{METHODS}

\section{Criteria for considering studies for this review \\ Types of studies}

All RCTs and quasi-RCTs (RCTs in which allocation to treatment was obtained by alternation, use of alternate medical records, date of birth, or other predictable methods) of individuals with resistant hypertension undergoing renal sympathetic denervation procedures, without duration or language restrictions.

\section{Types of participants}

Adults (older than 18 years), with refractory or resistant hypertension, defined by the presence of a clinic blood pressure above target (higher than $140 / 90 \mathrm{mmHg}$, or higher than $130 / 80$ $\mathrm{mmHg}$ in individuals with type 2 diabetes mellitus), despite the concomitant use of three or more antihypertensive drugs of different classes, including a diuretic.

\section{Types of interventions}

Any transcatheter renal sympathetic denervation procedures performed using contemporary percutaneous catheters and radiofrequency probes compared with standard medical therapy or sham intervention.

\section{Types of outcome measures}

\section{Primary outcomes}

- Fatal and non-fatal cardiovascular events, including but not limited to myocardial infarction, cerebrovascular accidents, and congestive heart failure

- All-cause mortality

- Any hospitalisation and duration of hospital stay (if long-term data are available)

- Quality of life (assessed using validated scales or any other instrument as reported by authors, such as the Short-Form Health Survey (SF-36)) 


\section{Secondary outcomes}

- Blood pressure control (change in office and clinic systolic, diastolic, and mean blood pressure)

- Left ventricular hypertrophy

- Atrial fibrillation episodes

- Obstructive sleep apnoea severity (apnoea-hypopnoea index)

- Kidney function (change in serum creatinine, glomerular filtration rate (GFR), proteinuria or albuminuria, need for renal replacement therapy)

- Metabolic profile (change in lipid and blood glucose levels and insulin resistance indices)

- Withdrawal due to adverse effects, including but not limited to bradycardia and hypotensive episodes, femoral artery pseudoaneurysm, renal artery dissection, transient dizziness, pitting oedema, flank pain, and anaemia

\section{Search methods for identification of studies}

\section{Electronic searches}

The Cochrane Hypertension Information Specialist conducted systematic searches in the following databases for randomised controlled trials without language, publication year or publication status restrictions:

- the Cochrane Hypertension Specialised Register via the Cochrane Register of Studies (CRS-Web) (searched 16 February 2016);

- the Cochrane Central Register of Controlled Trials (CENTRAL; 2016, Issue 2) via the Cochrane Register of Studies Online (CRSO) (searched 15 February 2016);

- MEDLINE Ovid (from 1946 onwards), and MEDLINE Ovid InProcess \& Other Non-Indexed Citations (searched 15 February 2016);

- PubMed (searched 16 February 2016);

- Embase Ovid (searched 15 February 2016);

- ClinicalTrials.gov (www.clinicaltrials.gov) searched 15 February 2016);

- World Health Organization International Clinical Trials Registry Platform (www.who.int/trialsearch) searched 15 February 2016).

The Information Specialist modelled subject strategies for databases on the search strategy designed for MEDLINE. Where appropriate, they were combined with subject strategy adaptations of the highly sensitive search strategy designed by Cochrane for identifying randomised controlled (as described in the Cochrane Handbook for Systematic Reviews of Interventions Version 5.1.0, Box 6.4.b. (Handbook 2011)). Search strategies for major databases are provided in Appendix 1.

\section{Searching other resources}

- The Cochrane Hypertension Information Specialist searched the Hypertension Specialised Register segment (which includes searches of MEDLINE and Epistemonikos for systematic reviews) to retrieve existing systematic reviews relevant to this systematic review, so that we could scan their reference lists for additional trials.
- We checked the bibliographies of included studies and any relevant systematic reviews identified for further references to relevant trials.

- Where necessary, we contacted authors of key papers and abstracts to request additional information about their trials.

- We did not perform a separate search for adverse effects of interventions used for the treatment of hypertension. We considered adverse effects described in included studies only.

- We checked the reference lists of cardiology and nephrology textbooks for additional resources.

\section{Data collection and analysis}

\section{Selection of studies}

Two authors (AP and LR) independently screened titles and abstracts, and retained studies and reviews that might include relevant data or information on trials for review in detail; studies that were not applicable were excluded. The same authors (AP and LR) independently assessed retrieved abstracts, and if necessary the full text, of these studies to determine which studies satisfied the inclusion criteria.

\section{Data extraction and management}

Two authors (AP and LR) independently carried out data extraction using a standard electronic data extraction form. We arranged for translations of studies reported in non-English language journals before assessment. If more than one publication of a study existed, we grouped the reports together and used the publication with the most complete data in the analyses. If relevant outcomes were published only in earlier versions of the study, we used such data.

\section{Assessment of risk of bias in included studies}

Two authors (AP and DB) independently assessed the following items using the 'Risk of bias' assessment tool (Higgins 2011).

- Sequence generation (selection bias);

- Allocation concealment (selection bias);

- Blinding (detection bias)

* Participants and personnel

* Outcome assessors;

- Completeness of outcome data (attrition bias);

- Selective outcome reporting (reporting bias);

- Other sources of bias:e.g. funding bias.

\section{Measures of treatment effect}

We expressed dichotomous outcome results as risk ratios (RRs) with $95 \%$ confidence intervals $(\mathrm{Cl})$. Where continuous scales of measurement were used to assess the effects of treatment, we reported results as mean differences (MD) or standardised mean differences (SMD) if different scales were reported, with $95 \% \mathrm{CI}$.

\section{Unit of analysis issues}

We appraised unit of analysis issues according to the Cochrane Handbook for Systematic Reviews of Interventions (Higgins 2011)

\section{Dealing with missing data}

We requested additional information from the corresponding author(s) by email. We carefully evaluated important data, such as numbers of screened and randomised participants, 
as well as numbers of intention-to-treat, as-treated, and perprotocol populations. We explored attrition in the study, such as drop-outs, losses to follow-up, and withdrawals. We appraised issues of missing data and imputation methods (such as lastobservation-carried-forward) according to the Cochrane Handbook for Systematic Reviews of Interventions (Higgins 2011).

\section{Assessment of heterogeneity}

We tested heterogeneity with a $\mathrm{Chi}^{2}$ test on $\mathrm{n}-1$ degrees of freedom, using an alpha of 0.05 for statistical significance, and used the $I^{2}$ statistic (Higgins 2003). We considered $I^{2}$ values of $25 \%$, $50 \%$, and $75 \%$ to correspond to low, medium, and high levels of heterogeneity.

\section{Assessment of reporting biases}

Where possible, we had planned to construct funnel plots to assess for the potential existence of small study bias (Higgins 2011).

\section{Data synthesis}

We analysed data for each outcome using Review Manager 5.3 (RevMan 2014) in an attempt to estimate the overall effect. We used the Mantel-Haenszel method for the fixed-effect model, except when statistical heterogeneity was observed, in which case we applied the random-effects model, to ensure robustness of the model chosen and susceptibility to outliers.

\section{Subgroup analysis and investigation of heterogeneity}

We had planned subgroup analyses to explore possible sources of heterogeneity (e.g. participants, treatments). Heterogeneity among participants could be related to age, the presence of comorbidities (e.g. diabetes, cardiovascular diseases), the presence or severity of renal function impairment, and the duration and severity of hypertension (e.g. number and dosage of antihypertensive drugs used). Heterogeneity in treatments could be related to the type and duration of the renal sympathetic denervation procedure and the type of catheter and radiofrequency probe used. We also planned an exploration of the effect of short- and long-term follow-up as a source of significant heterogeneity between studies.

\section{Sensitivity analysis}

If applicable, we had planned sensitivity analyses to explore the influence of the following factors on effect size:
- repeating the analysis excluding any large studies, to establish how much they impact on the results;

- repeating the analysis taking into account the risk of bias;

- repeating the analysis excluding unpublished studies.

\section{Summary of findings' table}

We had planned to construct a summary table via the GRADEproGDT(GRADEpro GDT 2015), reporting:

- a summary of findings from all the primary outcomes

- a summary of findings from some secondary outcomes, that have been pre-selected according to their clinical importance. These include blood pressure outcomes ( 24 h-ABPM and office blood pressure), renal function (serum creatinine and eGFR), bradycardia and hypotensive episodes.

- the quality of the body of evidence supporting each of these outcomes

\section{RE S U L T S}

\section{Description of studies}

The literature search was current to 17 February 2016.

\section{Results of the search}

The search identified 1057 records; we also identified two additional records from personal searches. Full-text assessment of 157 records resulted in the inclusion of twelve eligible studies (58 articles), comprising a total of 1149 participants (DENER-HTN 2015; Desch 2015; Franzen 2012; Oslo RDN 2014; Prague-15 2016; RELIEF 2012; SYMPLICITY HTN-2 2010; SYMPLICITY HTN-3 2014; Warchol 2014; Xiang 2014; HTN-JAPAN 2015; ReSET 2015), and 26 ongoing trials ( 30 articles; INSPIRED; DEPART; RENO; RSD4CKD; ReSET-2; RENSYMPIS; NCT01848275; RDNP-2012-01; ALLEGROHTN; PaCE; EnligHTN IV; RAPID II; NCT01968785; SYMPLICITY HTN-4; KPS; NCT02021019; DENERVHTA; ENSURE; NCT02346045; RSDforAF; SYMPATHY; NCT02444442; NCT02608632; NCT02667912; NCT01918111; NTR3444). We contacted the authors of some of the included studies for additional information about study methods, and unreported data; three investigators responded to our queries (DENER-HTN 2015; Prague-15 2016; SYMPLICITY HTN-2 2010). Figure 1 depicts the flow of study selection. 
Figure 1. Study flow diagram.

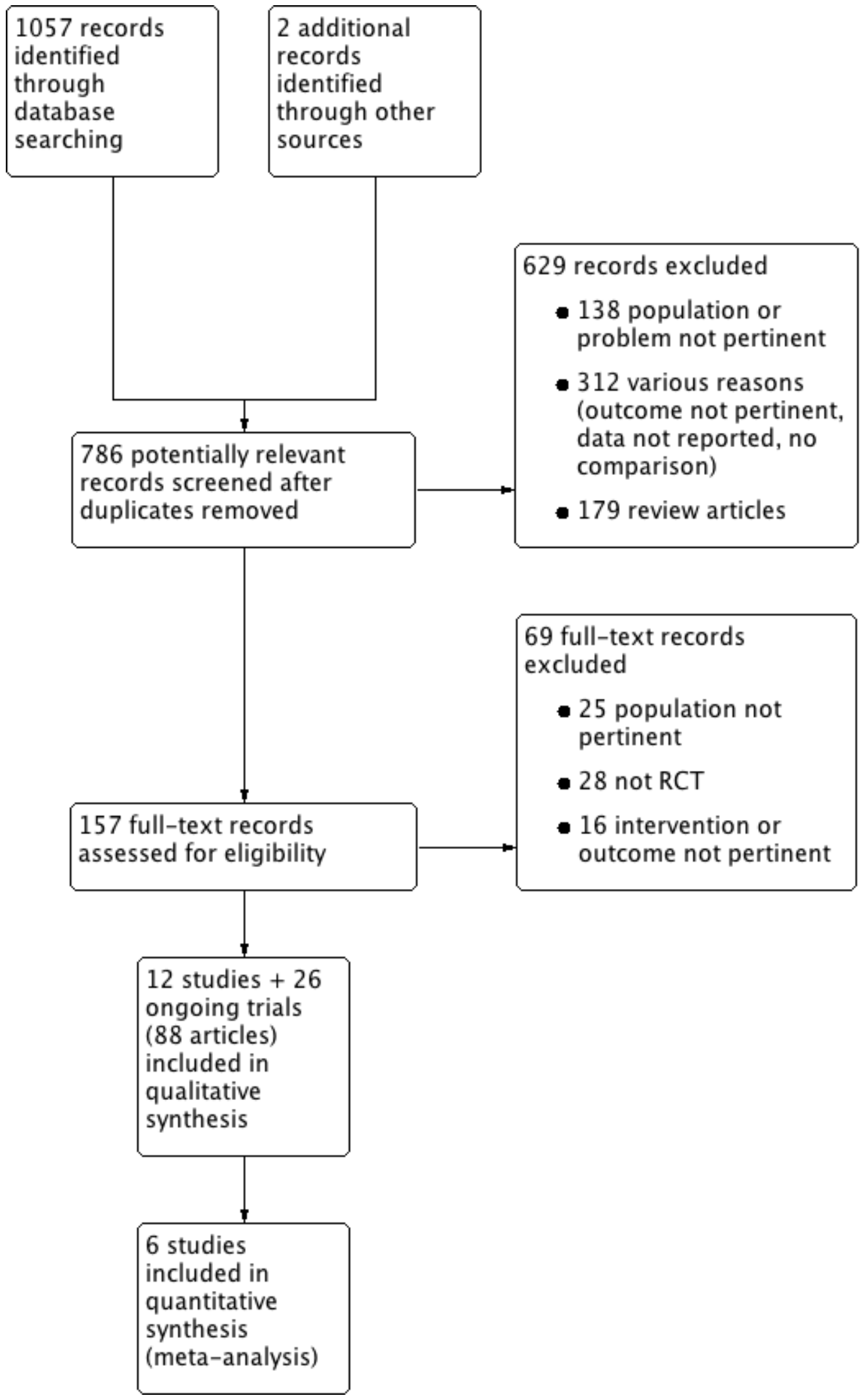




\section{Included studies}

All twelve included studies were parallel RCTs (Characteristics of included studies). All studies were conducted in adults. Study duration ranged from 3 to 12 months. All studies except DENERHTN 2015, Warchol 2014, and ReSET 2015 excluded patients with estimated glomerular filtration rate (eGFR) less than $45 \mathrm{~mL}$ / $\min / 1.73 \mathrm{~m}^{2}$. The renal sympathetic denervation procedure was performed with the electrode radiofrequency Symplicity catheter system in nine studies (DENER-HTN 2015; Desch 2015; Oslo RDN 2014; Prague-15 2016; SYMPLICITY HTN-2 2010; SYMPLICITY HTN-3 2014; Warchol 2014; HTN-JAPAN 2015; ReSET 2015). Ablation was performed with an off-the-shelf saline-irrigated radiofrequency catheter in RELIEF 2012. In Xiang 2014, ablation was made with the IBI-Therapy, St. Jude Medical radiofrequency catheter. In Franzen 2012, details of the denervation procedure were not provided. In seven studies, a series of four to six ablations per renal artery was performed (DENER-HTN 2015; Desch 2015; Prague-15 2016; SYMPLICITY HTN-2 2010; SYMPLICITY HTN-3 2014; Xiang 2014; HTN-JAPAN 2015). In Oslo RDN 2014, an average of eight (range 6 to11) radiofrequency ablations were applied per renal artery. The number of ablations was not reported in four studies (Franzen 2012; RELIEF 2012; Warchol 2014; ReSET 2015). In four studies, renal denervation was compared to sham procedure (Desch 2015; RELIEF 2012; SYMPLICITY HTN-3 2014; ReSET 2015). Xiang 2014 compared a proximal ablation to a complete renal artery denervation. SYMPLICITY HTN-2 2010, Warchol 2014, Franzen 2012, and HTN-JAPAN 2015 compared renal denervation plus antihypertensive medications with antihypertensive medications alone. In three studies, the effects of renal denervation plus standard antihypertensive therapy were tested against an intensified pharmacological regimen (DENER-HTN 2015; Oslo RDN 2014; Prague-15 2016). Outcomes available from studies were: incidence of myocardial infarction
(DENER-HTN 2015; Oslo RDN 2014; Prague-15 2016; SYMPLICITY HTN-3 2014), ischaemic stroke (DENER-HTN 2015; Prague-15 2016; SYMPLICITY HTN-2 2010; SYMPLICITY HTN-3 2014), unstable angina (Prague-15 2016; SYMPLICITY HTN-2 2010), all-cause-mortality and hospitalisations (SYMPLICITY HTN-3 2014), 24-hour ambulatory blood pressure monitoring (ABPM) or blood pressure (BP; DENERHTN 2015; Desch 2015; Oslo RDN 2014; Prague-15 2016; RELIEF 2012; SYMPLICITY HTN-3 2014; Warchol 2014; ReSET 2015; HTNJAPAN 2015), office ABPM or BP (DENER-HTN 2015; Oslo RDN 2014; Prague-15 2016; RELIEF 2012; SYMPLICITY HTN-2 2010; SYMPLICITY HTN-3 2014; Warchol 2014; Xiang 2014; HTN-JAPAN 2015), home BP (DENER-HTN 2015; HTN-JAPAN 2015), left ventricular hypertrophy (Prague-15 2016), and kidney function (serum creatinine, eGFR; DENER-HTN 2015; Prague-15 2016; SYMPLICITY HTN-2 2010; SYMPLICITY HTN-3 2014; HTN-JAPAN 2015). In addition, DENERHTN 2015; Desch 2015; Oslo RDN 2014; Prague-15 2016; SYMPLICITY HTN-2 2010; SYMPLICITY HTN-3 2014; Xiang 2014, and HTN-JAPAN 2015 looked systematically at the incidence of adverse effects associated to the procedure.

\section{Excluded studies}

We excluded 698 records, 629 of which were excluded at title and abstract screening (Figure 1). Sixty-nine records were excluded after full-text evaluation. Reasons for exclusion were: inappropriate population, problem, or both (163 reports); inappropriate intervention, outcome, or both (328 reports); not an RCT (28 reports); editorial, comment or letter without reporting randomised trial data (179 reports). See Characteristics of excluded studies.

\section{Risk of bias in included studies}

We have shown summaries of the risks of bias in the included studies in Figure 2 and Figure 3.

\section{Figure 2. Risk of bias graph: review authors' judgements about each risk of bias item presented as percentages} across all included studies.

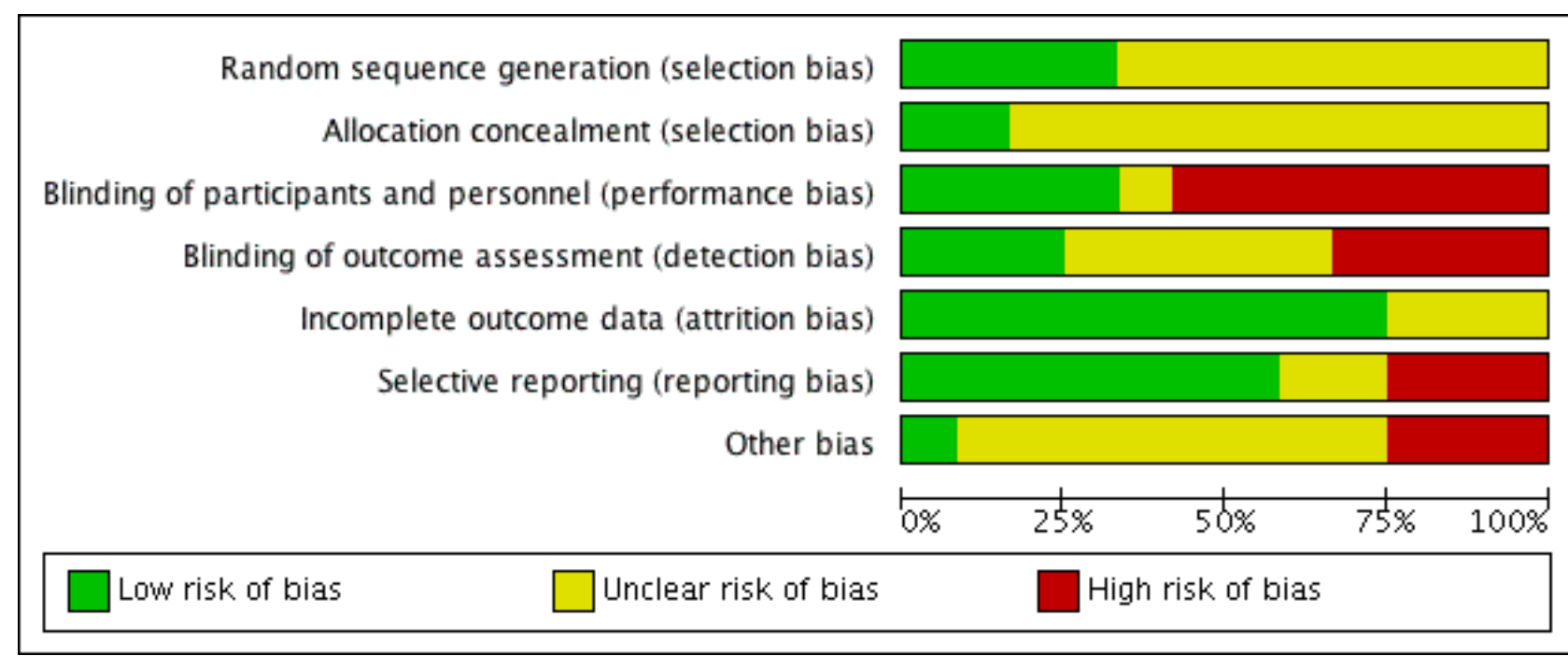


Figure 3. Risk of bias summary: review authors' judgements about each risk of bias item for each included study.

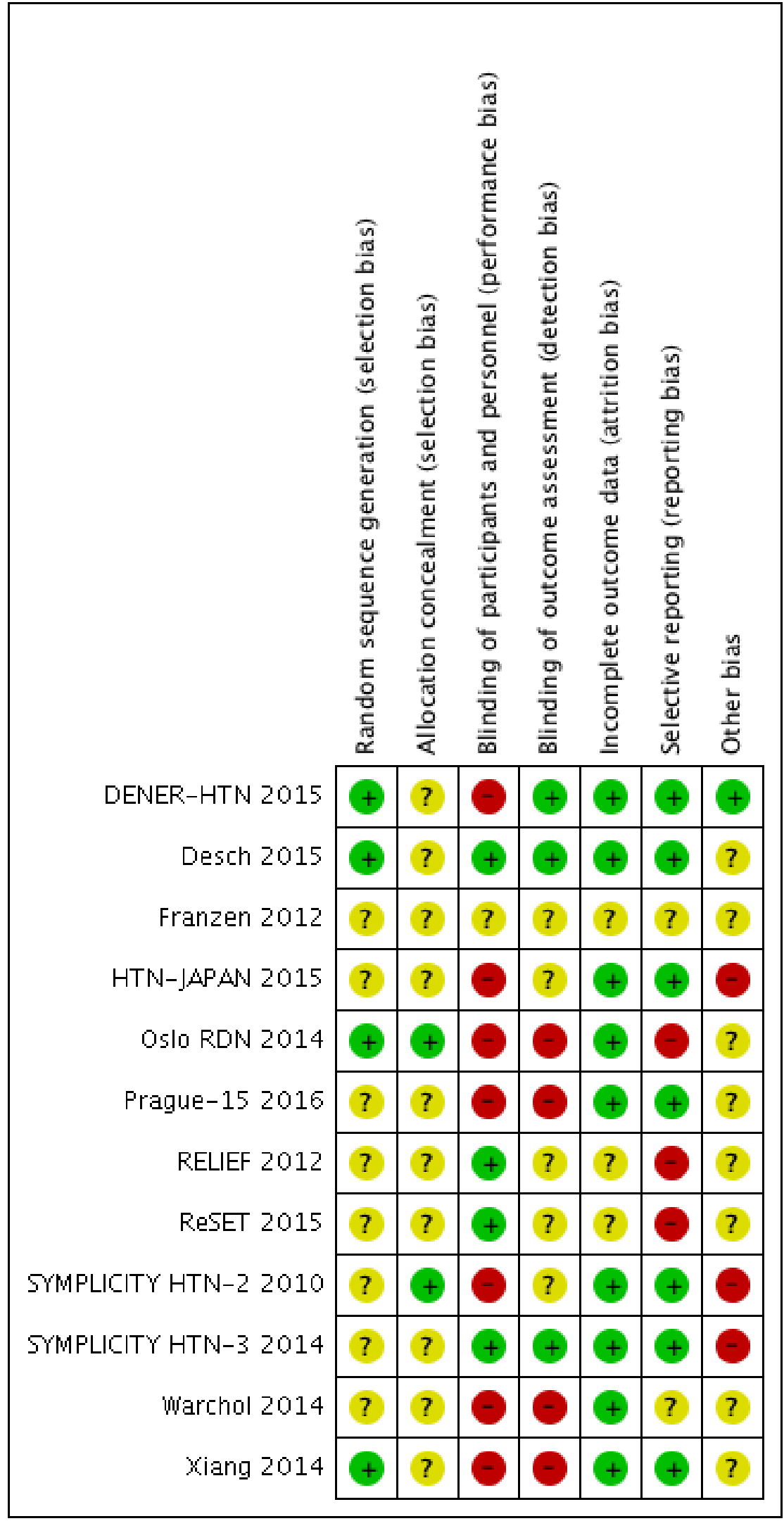




\section{Allocation}

The overall risk of selection bias was highly variable. Random sequence generation was detailed in four studies with a low risk of bias (DENER-HTN 2015; Desch 2015; Oslo RDN 2014; Xiang 2014), while there were insufficient data to inform assessment in the remainder. Only two of the included studies adequately described the allocation concealment methodologies that were applied (Oslo RDN 2014; SYMPLICITY HTN-2 2010); this information was not stated in the remainder.

\section{Blinding}

The risk of performance and detection bias was also variable. Six studies were fully open label, thus allowing a high risk of both biases (Oslo RDN 2014; Prague-15 2016; SYMPLICITY HTN-2 2010; Warchol 2014; Xiang 2014; HTN-JAPAN 2015). DENER-HTN 2015 was an open-label trial but outcome assessors were blinded to the procedure. ReSET 2015 was double-blinded; participants and personnel were unaware of treatment arm, while blinding of outcome assessment was not stated. In Desch 2015 and SYMPLICITY HTN-3 2014, participants and outcome assessors were blinded to the treatment. In RELIEF 2012, patients were blinded to renal denervation or sham procedure, while outcome assessor blinding was unclear. In Franzen 2012, no overall information on blinding was specified.

\section{Incomplete outcome data}

The overall drop-out rate ranged from $3 \%$ to $37 \%$ with no differences among groups, with the exception of DENER-HTN 2015 and SYMPLICITY HTN-3 2014, in which drop-outs were more prevalent in the treatment arm, and in Prague-15 2016, in which 31 participants $(62 \%)$ dropped out from the control group. Four studies reported no drop-outs (Oslo RDN 2014; Warchol 2014; Xiang 2014; HTN-JAPAN 2015). The information provided on attrition bias was insufficient to permit assessment in three studies (Franzen 2012; RELIEF 2012; ReSET 2015). Six studies were analysed on an intention-to-treat basis (DENER-HTN 2015; Oslo RDN 2014; SYMPLICITY HTN-3 2014; Warchol 2014; Xiang 2014; HTN-JAPAN 2015). In SYMPLICITY HTN-2 2010, analyses were performed on a per-protocol basis. In Desch 2015 and Prague-15 2016, results were analysed on both a per-protocol and intention-to-treat basis.

\section{Selective reporting}

All the predefined outcomes were reported in seven studies (DENER-HTN 2015; Desch 2015; Prague-15 2016; SYMPLICITY HTN-2 2010; SYMPLICITY HTN-3 2014; Xiang 2014; HTN-JAPAN 2015). Some prespecified outcomes were not reported in RELIEF 2012 (office BP, serum creatinine) or in ReSET 2015 (daytime and night time BP, dipping status, diastolic and systolic ventricular function, left ventricular hypertrophy, renal sodium excretion, pulse wave velocity, a $25 \%$ or more decline in eGFR). Possible selective reporting was unclear in the remainder.

\section{Other potential sources of bias}

Five studies declared to be funded from industry (DENER-HTN 2015; Oslo RDN 2014; SYMPLICITY HTN-2 2010; SYMPLICITY HTN-3 2014; HTN-JAPAN 2015). In DENER-HTN 2015, the authors stated that the sponsor had no role in the study design, data collection, data analysis, data interpretation, or writing of the report. In Oslo RDN 2014, the involvement of industry was unclear. In SYMPLICITY HTN-2 2010, SYMPLICITY HTN-3 2014, and HTN-JAPAN
2015 the authors declared that data were monitored, collected, and managed by the sponsor. No other sources of apparent bias were noticed in the other studies.

\section{Effects of interventions}

See: Summary of findings for the main comparison

The main effects of renal denervation on the primary outcomes and on the most important secondary outcomes are summarized in Summary of findings for the main comparison.

\section{Primary outcomes}

\section{Non-fatal cardiovascular events}

In a meta-analysis of four studies (742 participants), renal denervation was not significantly associated with a lower risk of myocardial infarction than sham or standard treatment (RR 1.31, $95 \% \mathrm{Cl} 0.45$ to 3.84 ; Analysis 1.1 ); there was no heterogeneity $\left(\mathrm{Chi}^{2}=0.79 ; \mathrm{P}=0.85 ; \mathrm{I}^{2}=0 \% ;\right.$ DENER-HTN 2015; Oslo RDN 2014; Prague-15 2016; SYMPLICITY HTN-3 2014). In data pooled from four studies (823 participants), renal denervation was not significantly associated with a lower risk of ischaemic stroke than no treatment ( $\mathrm{RR} 1.15,95 \% \mathrm{Cl} 0.36$ to 3.72 ; Analysis 1.2); there was no heterogeneity $\left(\mathrm{Chi}^{2}=1.27 ; \mathrm{P}=0.74 ; \mathrm{I}^{2}=0 \%\right.$; DENER-HTN 2015; Prague-15 2016; SYMPLICITY HTN-2 2010; SYMPLICITY HTN-3 2014). In a meta-analysis of two studies (201 participants), renal denervation was not associated with a lower risk of unstable angina than standard therapy (RR $0.63,95 \% \mathrm{Cl} 0.08$ to 5.06; Analysis 1.3); there was no heterogeneity $\left(\mathrm{Chi}^{2}=0.29 ; \mathrm{P}=0.59 ; \mathrm{I}^{2}=0 \%\right.$; Prague- 15 2016; SYMPLICITY HTN-2 2010).

\section{All-cause mortality}

Data on all-cause mortality were provided by one study, in which two patients in the renal denervation group and one in the sham procedure group died (SYMPLICITY HTN-3 2014).

\section{Hospitalisation}

Data on hospitalisation were only available in SYMPLICITY HTN-3 2014. Five patients in the renal denervation and one patient in the sham group had hospital admissions for atrial fibrillation episodes; nine patients in the renal denervation group and three in the sham group required hospitalisation for a new-onset of heart failure.

\section{Secondary outcomes}

\section{4-hour ambulatory blood pressure monitoring (ABPM)}

Twenty-four hour ABPM was measured in eight studies (DENERHTN 2015; Desch 2015; Oslo RDN 2014; Prague-15 2016; RELIEF 2012; SYMPLICITY HTN-3 2014; HTN-JAPAN 2015; ReSET 2015). In a meta-analysis of five studies (797 participants), renal denervation did not produce significant changes in systolic 24-hour ABPM when compared with sham or standard therapy (MD $0.28 \mathrm{mmHg}, 95 \%$ $\mathrm{Cl}-3.74$ to 4.29; Analysis 1.4); there was low heterogeneity $\left(\mathrm{Chi}^{2}=\right.$ 7.27; P = 0.12; $\left.\right|^{2}=45 \%$; DENER-HTN 2015; Oslo RDN 2014; Prague-15 2016; SYMPLICITY HTN-3 2014; HTN-JAPAN 2015). Similarly, renal denervation was not superior to sham or standard therapy in reducing diastolic 24-hour ABPM (4 studies, 756 participants; MD $0.93 \mathrm{mmHg}, 95 \% \mathrm{Cl}-4.50$ to 6.36 ; Analysis 1.5$)$. There was high heterogeneity in this latter analysis $\left(\mathrm{Chi}^{2}=22.50, \mathrm{P}<0.0001 ; \mathrm{I}^{2}\right.$ $=87 \%$ ) that could not be further explained due to the paucity 
of studies available (DENER-HTN 2015; Oslo RDN 2014; Prague-15 2016; SYMPLICITY HTN-3 2014).

In RELIEF 2012, the 24-hour systolic/diastolic BP decreased by $-17 /-12 \mathrm{mmHg}(P=0.006 / \mathrm{P}=0.001)$ in the bilateral renal denervation group versus $-5 /-5 \mathrm{mmHg}(P=0.22 / P=0.42)$ in the sham control group. In ReSET 2015, renal denervation (RD) and sham procedures showed a similar reduction in 24-hour systolic ABPM after six-month follow-up $(-6.1 \pm 18.9$ (RD) versus $-4.3 \pm 15.1$ $\mathrm{mmHg}$ (sham)). HTN-JAPAN 2015 recorded no difference between groups in 24-hour diastolic BP $(-3.8 \mathrm{mmHg}, 95 \% \mathrm{Cl}-8.3$ to 0.6 ; $\mathrm{P}$ $=0.091$ ). In Desch 2015, the mean change for the 24-hour systolic BP was $-7.0 \mathrm{mmHg}(95 \% \mathrm{Cl}-10.8$ to -3.2$)$ for patients undergoing renal denervation and $-3.5 \mathrm{mmHg}(95 \% \mathrm{Cl}-6.7$ to -0.2$)$ in the sham group $(P=0.15)$, as analysed on an intention-to-treat basis. In the per-protocol population, the change in 24-hour systolic BP at six months was $-8.3 \mathrm{mmHg}(95 \% \mathrm{Cl}-11.7$ to -5.0$)$ for patients undergoing renal denervation and $-3.5 \mathrm{mmHg}(95 \% \mathrm{Cl}-6.8$ to -0.2$)$ in the sham group $(P=0.042)$. No statistically significant changes in 24-hour diastolic BP were recorded in either the intention-to-treat or per-protocol analysis. All these single-study data were directly retrieved from the correspondent papers.

\section{Office BP}

In separate meta-analyses of six studies (886 participants) and five studies (845 participants), renal denervation had no conclusive effects on systolic or diastolic office BP when compared with sham procedure or standard therapy (systolic: MD $-4.08 \mathrm{mmHg}, 95 \%$ Cl -15.26 to 7.11; Analysis 1.6; DENER-HTN 2015; Oslo RDN 2014; Prague-15 2016; SYMPLICITY HTN-2 2010; SYMPLICITY HTN-3 2014; HTN-JAPAN 2015; diastolic: MD $-1.30 \mathrm{mmHg}, 95 \% \mathrm{Cl}-7.30$ to 4.69; Analysis 1.7; DENER-HTN 2015; Oslo RDN 2014; Prague-15 2016; SYMPLICITY HTN-2 2010; SYMPLICITY HTN-3 2014. There was high heterogeneity in these analyses $\left(\mathrm{Chi}^{2}=59.87 ; \mathrm{P}<0.00001 ;\left.\right|^{2}=92 \%\right.$ and $\mathrm{Chi}^{2}=27.44 ; \mathrm{P}<0.00001 ; \mathrm{I}^{2}=85 \%$, respectively) that could not be further explained due to the low number of studies included.

In Xiang 2014, at six-month follow-up, the average office systolic/ diastolic BP decreased significantly from 191.2/98.3 at baseline to $136.3 / 80.2 \mathrm{mmHg}$ in the group undergoing proximal ablation, and from $181.4 / 98.5$ to $136.5 / 79.5 \mathrm{mmHg}$ in the group undergoing the whole ablation. HTN-JAPAN 2015 recorded a greater average diastolic office BP reduction in the renal denervation group than in the control group, with a change difference of $-6.9 \mathrm{mmHg}(95 \%$ $\mathrm{Cl}-13.2$ to $0.5 ; \mathrm{P}=0.036$ ). These data were obtained from the correspondent study article.

\section{Home BP}

In HTN-JAPAN 2015, no change difference in home systolic and diastolic BP was observed between the renal denervation and control groups $(-5.6 \mathrm{mmHg}(95 \% \mathrm{Cl}-14.5$ to $3.2 ; \mathrm{P}=0.205)$ and -4.8 $\mathrm{mmHg}(95 \% \mathrm{Cl}-9.8$ to $0.3 ; \mathrm{P}=0.065)$, respectively). In DENER-HTN 2015 , the mean change in home systolic and diastolic BP was -15.4 $\mathrm{mmHg}(95 \% \mathrm{Cl}-20.4$ to -10.4$)$ and $-8.7 \mathrm{mmHg}(95 \% \mathrm{Cl}-12.1$ to -5.4$)$ in patients undergoing renal denervation and $-11.8 \mathrm{mmHg}(95 \%$ $\mathrm{Cl}-16.5$ to -7.1$)$ and $-6.7 \mathrm{mmHg}(95 \% \mathrm{Cl}-9.8$ to -3.5$)$ in the control group, with no differences between groups $(P=0.30$ and $P=0.37)$ for systolic and diastolic BP, respectively.

\section{Left ventricular mass (LVH)}

Twelve-month follow-up data on left ventricular mass (LVM) and LVM indexed (LVMI) were provided by one study, which reported no significant difference in change between the renal denervation and control groups $(10(95 \% \mathrm{Cl}-13$ to 33$)$ and $2.3(95 \% \mathrm{Cl}-2.7$ to 7.4$)$ for LVM and LVMI, respectively (Prague-15 2016).

\section{Kidney function}

In a meta-analysis of three studies (736 participants), renal denervation had no tangible effects over sham or standard treatment on serum creatinine levels (MD $0.01 \mathrm{mg} / \mathrm{dL}, 95 \% \mathrm{Cl}-0.12$ to 0.14 ; Analysis 1.8$)$, with high heterogeneity $\left(\mathrm{Chi}^{2}=12.75 ; \mathrm{P}=\right.$ $0.002 ; I^{2}=84 \%$ ), which could not be further explored, as only three studies were included (Prague-15 2016; SYMPLICITY HTN-2 2010; SYMPLICITY HTN-3 2014). Nevertheless, SYMPLICITY HTN-3 2014 reported five cases in the renal denervation group and one case in the sham group, who had an increase in serum creatinine levels greater than $50 \%$ from baseline. One case of $50 \%$ increase in serum creatinine was also reported in the renal denervation group after six months of follow-up in HTN-JAPAN 2015.

In another meta-analysis of four studies (837 participants), renal function, as estimated by eGFR or creatinine clearance, remained unaffected after renal denervation compared to control (MD -2.09 $\mathrm{mL} / \mathrm{min}, 95 \% \mathrm{Cl}-8.12$ to 3.95 ; Analysis 1.9 ), with moderate heterogeneity $\left(\mathrm{Chi}^{2}=7.09, \mathrm{P}=0.07 ; \mathrm{I}^{2}=58 \%\right)$, which could not be further explored (DENER-HTN 2015; Prague-15 2016; SYMPLICITY HTN-2 2010; SYMPLICITY HTN-3 2014).

Prague-15 2016 recorded an unspecified decline in renal function in one patient undergoing the standard treatment.

\section{Adverse events}

Major adverse events were systematically collected by seven studies (DENER-HTN 2015; Oslo RDN 2014; Prague-15 2016; SYMPLICITY HTN-2 2010; SYMPLICITY HTN-3 2014; Xiang 2014; HTN-JAPAN 2015). HTN-JAPAN 2015 reported no periprocedural complications in either the renal denervation or control arms. No study provided information on the occurrence of transient dizziness or anaemia.

\section{Bradycardia}

In a meta-analysis of three studies (220 participants), renal denervation was significantly associated with an almost seven-fold higher risk of bradycardia symptoms than other treatments (RR $6.63,95 \% \mathrm{Cl} 1.19$ to 36.84 ; Analysis 1.10 ), with no heterogeneity $\left(\mathrm{Chi}^{2}=0.63 ; \mathrm{P}=0.73 ; \mathrm{I}^{2}=0 \%\right.$; Oslo RDN 2014; Prague-15 2016; SYMPLICITY HTN-2 2010).

\section{Femoral artery pseudoaneurysm}

Pooled data from two studies (201 participants) showed that renal denervation was not statistically associated with a higher risk for femoral artery pseudoaneurysm than standard therapy (RR 3.96, $95 \% \mathrm{Cl} 0.44$ to 35.22 ; Analysis 1.11$)$, with no heterogeneity $\left(\mathrm{Chi}^{2}=\right.$ 0.04; P = 0.84; $I^{2}=0 \%$; Prague-15 2016; SYMPLICITY HTN-2 2010).

\section{Renal artery dissection}

In Prague-15 2016, there was one case of renal artery dissection related to the procedure. 


\section{Renal artery vasospasm}

Four cases of renal artery vasospasm in patients undergoing renal denervation were observed in Prague-15 2016. Xiang 2014 reported two cases of renal artery vasospasm in the whole ablation group versus none in the proximal ablation group.

\section{New renal-artery stenosis}

SYMPLICITY HTN-3 2014 reported one case of re-stenosis in the renal denervation group (documented as new renal artery stenosis of more than $70 \%$ ) within the six-month follow-up.

\section{Flank pain}

In a meta-analysis of two studies (199 participants), renal denervation was not significantly associated with a higher risk of flank pain than control (RR 4.30, 95\% Cl 0.48 to 38.28; Analysis 1.12), with no heterogeneity $\left(\mathrm{Chi}^{2}=0.08 ; \mathrm{P}=0.78 ; \mathrm{I}^{2}=0 \%\right.$; DENER-HTN 2015; SYMPLICITY HTN-2 2010).

\section{Pitting oedema}

One case of oedema requiring hospital admission was provided by SYMPLICITY HTN-2 2010.

\section{Hypotensive episodes}

In a meta-analysis of two studies (119 participants), the renal denervation procedure was not associated with a higher risk of hypotensive episodes than no treatment (RR $0.67,95 \% \mathrm{Cl} 0.07$ to 6.64; Analysis 1.13), with low heterogeneity $\left(\mathrm{Chi}^{2}=1.61 ; \mathrm{P}=0.20 ; \mathrm{I}^{2}\right.$ = 38\%; Oslo RDN 2014; SYMPLICITY HTN-2 2010).

\section{Hypertensive crisis}

In data pooled from three studies (722 participants), renal denervation was not significantly associated with a higher risk for hypertensive episodes than no treatment (RR $0.71,95 \% \mathrm{Cl} 0.35$ to 1.45; Analysis 1.14), with no heterogeneity $\left(\mathrm{Chi}^{2}=1.83 ; \mathrm{P}=0.40 ; \mathrm{I}^{2}=\right.$ 0\%; DENER-HTN 2015; SYMPLICITY HTN-2 2010; SYMPLICITY HTN-3 2014).

\section{Hyperkalemia}

In a meta-analysis of two studies (200 participants), patients in the renal denervation group had no higher risk of hyperkalaemia than those in standard therapy (RR $0.48,95 \% \mathrm{Cl} 0.01$ to 21.33 ; Analysis 1.15). There was moderate heterogeneity in this analysis $\left(\mathrm{Chi}^{2}=\right.$ 3.17; $P=0.07 ; I^{2}=68 \%$ ), which could not be further explored, as only two studies were included (Prague-15 2016; DENER-HTN 2015).

\section{Syncope}

In DENER-HTN 2015, one patient in the control group experienced an episode of syncope.

\section{Embolic event}

In SYMPLICITY HTN-3 2014, one case of embolic event resulting in end-organ damage was reported in the renal denervation group.

\section{Withdrawals}

Nine studies provided information on withdrawals (DENER-HTN 2015; Desch 2015; HTN-JAPAN 2015; Oslo RDN 2014; Prague-15 2016; SYMPLICITY HTN-2 2010; SYMPLICITY HTN-3 2014; Warchol 2014; Xiang 2014). SYMPLICITY HTN-3 2014 recorded 14 (3.8\%) withdrawals from the renal denervation group and two (1.2\%) from the control arm. In SYMPLICITY HTN-2 2010, there were three withdrawals from both the intervention and control arms. DENER-HTN 2015 reported five (10\%) withdrawals from the renal denervation group. In Desch 2015, six participants (17\%) withdrew from the renal denervation and two (5.55\%) from the sham group. Prague-15 2016 recorded seven (13.7\%) and 31 (62\%) withdrawals from the renal denervation and control groups, respectively. Four studies reported no withdrawals (Oslo RDN 2014; Warchol 2014; Xiang 2014; HTN-JAPAN 2015).

\section{Outcomes not stated}

No RCT provided data on the following outcomes: fatal cardiovascular events, quality of life, atrial fibrillation episodes, sleep apnoea severity, need for renal replacement therapy, proteinuria, albuminuria, or metabolic profile (blood glucose, insulin resistance).

\section{Sensitivity analyses, investigation of heterogeneity, and publication bias}

Although planned, such analyses were not performed due to the small number of studies retrieved and analysed.

\section{DISCUSSION}

\section{Summary of main results}

In patients with resistant hypertension, a renal denervation procedure did not reduce the risk of major cardiovascular events, including myocardial infarction, ischaemic stroke, and unstable angina, compared with controls. Furthermore, this procedure had no definite effects on 24-hour ABPM, office systolic or diastolic blood pressure, and no apparent benefits on renal function, while it increased the risk of bradycardia episodes. Conversely, renal denervation was not associated with a significantly higher risk of other adverse effects, such as femoral artery pseudo-aneurysm, flank pain, hypotensive or hypertensive episodes, and long-term hyperkalaemia. Data on mortality, hospitalisations, and other adverse effects were limited to single studies.

\section{Overall completeness and applicability of evidence}

The evidence on the benefits of this procedure remains inconclusive, and hence, poorly applicable in clinical practice. Many clinically relevant outcomes, such as fatal cardiovascular events, quality of life, sleep apnoea severity, need for renal replacement therapy, and metabolic profile, were not explored in any included RCT. Heterogeneity was high to very high in the majority of analyses carried out, hampering the overall reliability of findings. Although exploration of heterogeneity was not feasible due to the paucity of studies included in each analysis, it can be speculated that differences among individual study designs (e.g. use of sham procedure or standard therapy as control, presence or/ absence of blinding in outcome assessment) may represent one of the main causes underlying this phenomenon. In most trials, both study groups were simultaneously treated with optimal anti-hypertensive therapy to decrease blood pressure to an established target. Administration of these drugs was variable and non-reproducible. Procedural methods were also heterogeneous among studies, particularly in terms of type of catheter employed, number of applications, energy delivered and target portion of renal artery. Sakakura et al. recently observed that nervous fibres are mostly concentrated in the middle and proximal segments of 
the renal artery while their number decrease in the distal segment (Sakakura 2014). Recent data evidenced maximum procedural efficacy after ablation in the whole circumference of renal artery and a dose-response dependency directly related to the amount of energy delivered (Kandzari 2015).The lack of standardized methods for renal denervation may hamper the reliability of comparisons among studies and, in some cases, even raise the question as to whether the procedure was truly successful (Esler 2015). For instance, in a corollary analysis of the SYMPLICITY HTN-2 2010 trial the measurement of norepinephrine spillover seemed to indicate that in only $47 \%$ of patients renal denervation was truly achieved. Hence, technical bias should be considered in future trials as a potential cause of lack of response in many patients and reliable markers to confirm successful denervation are advocated. In addition, accumulating evidence indicated that the phenomena of re-innervation of renal arteries after denervation may seriously hamper the achievement of long term benefits (Booth 2015).

\section{Quality of the evidence}

The GRADE quality of the evidence (Guyatt 2008) was low for cardiovascular morbidity outcomes and adverse effects and moderate for blood pressure and renal function outcomes. The quality of evidence was mostly influenced by the imprecision of results (wide confidence intervals) and/or the low number of studies providing quantitative data on the same outcome.

\section{Potential biases in the review process}

Points of strength of this review are represented by a peerreviewed protocol, a systematic search of electronic databases, and data extraction, analysis, and 'Risk of bias' assessment completed independently by two authors, according to current methodological standards. The main limitation is represented by the data obtainable from the included studies. Studies were mainly focused on small populations and short treatment periods. As a result, most trials were not adequately powered to capture exhaustive information on hard, patient-centred outcomes, such as fatal or non-fatal cardiovascular events. The limited evidence available also prevented more complex analyses, such as sensitivity analyses, interaction tests, and analysis for publication bias.

\section{Agreements and disagreements with other studies or reviews}

In a recent systematic review, renal denervation was apparently efficacious in reducing mean blood pressure at six months in individuals with resistant hypertension (Davis 2013). Unfortunately, this review was mostly based on data from observational, uncontrolled studies with limited follow-up, small sample sizes, and high heterogeneity in blood pressure measurement. Findings from our review were in line with observations made by a more recent meta-analysis of the European Network Coordinating Research On Renal Denervation (ENCOReD) Consortium (Fadl Elmula 2015). The authors confirmed the current lack of evidence supporting a widespread use of this procedure in clinical practice, advocating for future clinical trials with a longer observation time, which enrol hypertensive patients with fewer comorbidities.

\section{AUTHORS' CONCLUSIONS}

\section{Implications for practice}

The evidence accrued so far is insufficient to support the use of renal denervation as a clinically useful procedure for improving cardiovascular risk and blood pressure control in patients with resistant hypertension. In patients with resistant hypertension, there is low quality evidence that renal denervation does not change major cardiovascular events, and renal function. There is moderate quality evidence that renal denervation does not change blood pressure and and low quality evidence that it caused an increase of bradycardia episodes.

\section{Implications for research}

Focused trials, powered for patient-centred instead of surrogate outcomes, with longer follow-up periods, larger sample sizes, more standardised procedural methods, and possibly examining particular subgroups of patients with resistant hypertension (e.g. subjects with different cardiovascular or renal risk profile) are needed to clarify the optimal target population for this procedure. Study design providing a sham control procedure and blinded outcome assessors are indispensable for minimising bias and improving reliability of findings.

\section{ACKNOWLEDGEMENTS}

We thank Dr Murray Esler, Dr Michel Azizi, and Dr Jan Rosa for providing additional trial data. We would also like to thank the Cochrane Hypertension Group, particularly Mr Ciprian Jauca and Mr Douglas Salzwedel, for their valuable support, and the referees for their feedback and advice during the preparation of the review. 


\section{R E F E R E N C E S}

\section{References to studies included in this review \\ DENER-HTN 2015 \{published data only\}}

* Azizi M, Sapoval M, Gosse P, Monge M, Bobrie G, Delsart P, et al. Optimum and stepped care standardised antihypertensive treatment with or without renal denervation for resistant hypertension (DENER-HTN): a multicentre, open-label, randomised controlled trial. Lancet 2015;385(9981):1957-65.

Forni O, Pereira V, Sapoval E, Azizi M. Prevalence and risk factors for refractory hypertension in the DENER-HTN study. Journal of Hypertension 2015;33:e51.

NCT01570777. Renal denervation in patients with resistant hypertension (DENER-HTN). clinicaltrials.gov/ct2/show/ NCT01570777 (first received 2 April 2012).

Sapoval MR, Monge M, Pereira H, Azizi M. DENER-HTN trial: a prospective randomized control trial of the efficacy of renal artery denervation in resistant hypertension. Cardiovascular and Interventional Radiology 2014;1:S341.

Desch 2015 \{published data only\}

* Desch S, Okon T, Heinemann D, Kulle K, Rohnert K, Sonnabend M, et al. Randomized sham-controlled trial of renal sympathetic denervation in mild resistant hypertension. Hypertension 2015;65:1202-8.

Fengler K, Heinemann D, Okon T, Röhnert K, Stiermaier T, von Röder M, et al. Renal denervation improves exercise blood pressure: insights from a randomized, sham-controlled trial. Clinical Research in Cardiology 2016;105(7):592-600. [DOI: 10.1007/s00392-015-0955-8]

NCT01656096. Renal sympathetic denervation in patients with mild refractory hypertension. clinicaltrials.gov/ct2/show/ NCT01656096 (first received 31 July 2012).

\section{Franzen 2012 \{published data only\}}

* Franzen KF, Mortensen K, Himmel F, Stritzke J, Koester J, Bock J, et al. Percutaneous renal denervation (PRD) improves central hemodynamics and arterial stiffness - a pilot study. European Heart Journal 2012;33:771.

\section{HTN-JAPAN 2015 \{published data only\}}

Kario K, Bhatt DL, Brar S, Cohen SA, Fahy M, Bakris GL. Effect of catheter-based renal denervation on morning and nocturnal blood pressure: insights from SYMPLICITY HTN-3 and SYMPLICITY HTN-Japan. Hypertension 2015;66:1130-7. [EMBASE: 10.1161/HYPERTENSIONAHA.115.06260]

* Kario K, Ogawa H, Okumura K, Okura T, Saito S, Ueno T, et al. SYMPLICITY HTN-Japan Investigators. SYMPLICITY HTNJapan - First randomized controlled trial of catheter-based renal denervation in Asian patients. Circulation Journal 2015;79:1222-9.

KarioK, Bakris G, Bhatt LD. Preferential reduction in morning/ nocturnal hypertension by renal denervation for drug-resistant hypertension: a new ABPM analysis of SYMPLICITY HTN-3 and
HTN-Japan. Journal of Hypertension 2015;33 Suppl 1:e52. [DOI: 10.1097/01.hjh.0000467484.20438.39]

NCT01644604. The clinical study of renal denervation by MDT-2211 system in patients with uncontrolled hypertension. clinicaltrials.gov/ct2/show/NCT01644604 (first received 29 June 2012).

\section{Oslo RDN 2014 \{published data only\}}

Fadl El Mula F, Hoffmann P, Larstorp AC, Brekke M, Fossum E, Stenehjem $A$, et al. Renal sympathetic denervation is inferior to adjusted drug treatment in patients with true treatment resistant hypertension, a randomized controlled trial. European Heart Journal 2014;35:718.

* Fadl Elmula F E, Hoffmann P, Larstorp A C, Fossum E, Brekke M, Kjeldsen S E, et al. Adjusted drug treatment is superior to renal sympathetic denervation in patients with true treatment-resistant hypertension. Hypertension 2014;63:991-9.

Fadl Elmula FEM, Hoffmann P, Larstorp AC, Hoieggen A, Kjeldsen $S$. Adjusted drug treatment is superior to renal sympathetic denervation in patients with true treatment resistant hypertension, a randomized clinical trial. Journal of the American College of Cardiology 2014;1:A1306.

NCT01673516. Effect of renal sympathetic denervation on resistant hypertension and cardiovascular hemodynamic in comparison to intensive medical therapy utilizing impedance cardiography (OsloRDN). clinicaltrials.gov/ct2/show/ NCT01673516 (first received 17 August 2012).

Prague-15 2016 \{published data only\} NCT01560312. Renal denervation in refractory hypertension. clinicaltrials.gov/ct2/show/NCT01560312 (first received 16 May 2011).

Rosa J, Widimsky P, Tousek P, Petrak O, Curila K, Waldauf P, et al. Randomized comparison of renal denervation versus intensified pharmacotherapy including spironolactone in true-resistant hypertension: six-month results from the Prague-15 study. Hypertension 2015;65:407-13.

* Rosa J, Widimsky P, Waldauf P, Lambert L, Zelinka T, Taborsky M, et al. Role of adding spironolactone and renal denervation in true resistant hypertension: one-year outcomes of randomized PRAGUE-15 study. Hypertension 2016;67:397-403.

Rosa J, Zelinka T, Petrak O, Strauch B, Somloova Z, Indra T, et al. Importance of thorough investigation of resistant hypertension before renal denervation: should compliance to treatment be evaluated systematically?. Journal of Human Hypertension 2014;28:684-8.

Tousek P, Widimsky J Jr, Rosa J, Curila K, Branny M, Nykl I, et al. Catheter-based renal denervation versus intensified medical treatment in patients with resistant hypertension: rationale and design of a multicenter randomized study - PRAGUE-15. Cor et Vasa 2014;56:e235-9. 
RELIEF 2012 \{published data only\}

Ahmed H, Neuzil P, Schejbalova M, Bejr M, Kralovec S, Reddy VY. Renal sympathetic denervation for the management of chronic hypertension (RELIEF): 40 patient analysis. Circulation 2012;1(126):A17520.

* Ahmed H, Neuzil P, Schejbalova M, Bejr M, Kralovec S, Reddy VY. Renal sympathetic denervation for the management of chronic hypertension (RELIEF): an interim analysis. Heart Rhythm 2012;1:S469-70.

NCT01628172. Renal sympathetic denervation for the management of chronic hypertension (RELIEF). clinicaltrials.gov/ct2/show/NCT01628172 (first received 2012).

\section{ReSET 2015 \{published data only\}}

* Mathiassen O, Bech JN, Buus NH, Christensen KL, Vase H, Bertelsen JB, et al. Renal sympathetic denervation in treatment resistant essential hypertension. A sham-controlled, doubleblinded randomized trial (ReSET trial). Journal of the American College of Cardiology 2015;66:B41.

NCT01459900. Renal sympathectomy in treatment resistant essential hypertension: a sham controlled randomized trial. clinicaltrials.gov/ct2/show/NCT01459900 (first received 2011).

\section{SYMPLICITY HTN-2 2010 \{published data only\}}

Boehm M, Schlaich MP, Krum H, Schmieder RE, Sobotka P, Esler MD. One-year pooled outcomes following renal sympathetic denervation in patients with resistant hypertension: from the SYMPLICITY HTN-2 trial. European Heart Journal 2012;33:770.

Esler M. SYMPLICITY HTN-2: international, multicenter, prospective, randomized, controlled trial of endovascular selective renal sympathetic denervation for the treatment of hypertension. Circulation 2010;122:2220.

Esler M D, Krum H, Schlaich M, Schmieder R, Bohm M, Sobotka P. Renal sympathetic denervation for treatment of resistant hypertension: One year results from the SYMPLICITY HTN-2 randomized controlled trial. Journal of the American College of Cardiology 2012;1):E1705.

Esler M, Krum H, Schmieder R, Bohm M. Renal sympathetic denervation for treatment of resistant hypertension: Two-year update from the SYMPLICITY HTN-2 randomized controlled trial. Journal of the American College of Cardiology 2013;1):E1386.

Esler MD, Bohm M, Sievert H, Rump CL, Schmieder RE, Krum H, et al. Catheter-based renal denervation for treatment of patients with treatment-resistant hypertension: 36-month results from the SYMPLICITY HTN-2 randomized clinical trial. European Heart Journal 2014;35:1752-9.

Esler MD, Krum H, Schlaich M, Schmieder RE, Bohm M, Sobotka PA, et al. Renal sympathetic denervation for treatment of drug-resistant hypertension: one-year results from the SYMLICITY HTN-2 randomized, controlled trial. Circulation 2012;126:2976-82.

Esler MD, Krum H, Schlaich MP, Schmieder RE, Boehm M, Sobotka P. Catheter-based renal sympathetic denervation in patients with resistant hypertension: 18-month follow-up of the SYMPLICITY HTN-2 trial. European Heart Journal 2012;33:181.

Esler MD, Krum H, Schlaich MP, Schmieder RE, Bohm M. Persistent and safe blood pressure lowering effects of renal artery denervation: three-year follow-up from the SYMPLICITY HTN-2 trial. Journal of the American College of Cardiology 2013;1:B19.

Fischer T. Renal sympathetic denervation for treatment of drug-resistant hypertension: one-year results from the SYMPLICITY HTN-2 randomized, controlled trial. Orvosi Hetilap 2014;155(21):843. [DOI: 10.1556/OH.2014.21M]

Murray E, Henry K, Marcus S, Roland S, Michael B. Long-term follow-up of catheter-based renal denervation in patients with treatment resistant hypertension: the SYMPLICITY HTN-2 trial. Journal of Clinical Hypertension 2013;15(Suppl 1):28.

NCT00888433. Renal denervation in patients with uncontrolled hypertension (SYMPLICITY HTN-2). clinicaltrials.gov/ct2/show/ NCT00888433 (first received 2009).

* Symplicity HTN-2 Investigators. Renal sympathetic denervation in patients with treatment-resistant hypertension (the SYMPLICITY HTN-2 Trial): a randomised controlled trial. Lancet 2010;376(9756):1903-9. [DOI: 10.1016/ S0140-6736(10)62039-9]

Ukena C, Mahfoud F, Ewen S, Kindermann I, Boehm M. Cardiorespiratory response to exercise after renal sympathetic denervation in resistant hypertension. Cardiology (Switzerland) 2013;125:158.

Ukena C, Mahfoud F, Kindermann I, Barth C, Lenski M, Kindermann $\mathrm{M}$, et al. Cardiorespiratory response to exercise after renal sympathetic denervation in patients with resistant hypertension. Journal of the American College of Cardiology 2011;58:1176-82.

Ukena C, Mahfoud F, Kindermann I, Kindermann M, Brandt MC Hoppe U, et al. Cardiorespiratory response to exercise after renal sympathetic denervation in patients with resistant hypertension. European Heart Journal 2011;32:960.

SYMPLICITY HTN-3 2014 \{published data only\}

Bakris GL, Townsend RR, Liu M, Cohen SA, D'Agostino R, Flack JM, et al. Impact of renal denervation on 24-hour ambulatory blood pressure: results from SYMPLICITY HTN-3. Journal of the American College of Cardiology 2014;64:1071-8.

Bakris GL, Townsend RR, Flack JM, Brar S, Cohen SA, D'Agostino, et al. Investigators for SYMPLICITY HTN-3. 12-month blood pressure results of catheter-based renal artery denervation for resistant hypertension: the SYMPLICITY HTN-3 trial. Journal of the American College of Cardiology 2015;65:1314-21.

Bhatt DL, Bakris GL. Long-term (24-month) blood pressure results of catheter-based renal artery denervation: SYMPLICITY HTN-3 randomized controlled trial. Journal of the American College of Cardiology 2015;1:B38-9. 
Bhatt DL, Kandzari DE, O'Neill WW. A controlled trial of renal denervation for resistant hypertension. Journal of Vascular Surgery 2014;60:266.

* Bhatt DL, Kandzari DE, O'Neill WW, D'Agostino R, Flack JM, Katzen BT, et al. A controlled trial of renal denervation for resistant hypertension. New England Journal of Medicine 2014;370:1393-401.

Divison JA, Escobar CC, Segui DM. Controlled clinical trial on renal denervation in resistant hypertension. Semergen 2014;40:345-6

Flack J, Bakris GL, Kandzari D, Katzen BT, Leon M, Mauri L, et al. SYMPLICITY HTN-3: outcomes in the African-American and NonAfrican American populations. Journal of the American College of Cardiology 2014;1:B119-20.

Flack JM, Bhatt DL, Kandzari DE, Brown D, Brar S, Choi J, et al. Investigators for SYMPLICITY HTN. An analysis of the blood pressure and safety outcomes to renal denervation in African Americans and Non-African Americans in the SYMPLICITY HTN-3 trial. Journal of the American Society of Hypertension 2015;9:769-79.

Kandzari DE, Bhatt DL, Brar S, Devireddy CM, Esler M, Fahy M, et al. Predictors of blood pressure response in the SYMPLICITY HTN-3 trial. European Heart Journal 2015;36:219-27.

Kandzari DE, Bhatt DL, Sobotka PA, O'Neill WW, Esler M, Flack JM, et al. Catheter-based renal denervation for resistant hypertension: rationale and design of the SYMPLICITY HTN-3 trial. Clinical Cardiology 2012;35:528-35.

Kario K, Bakris GL, Bhatt D. Preferential reduction in morning/ nocturnal hypertension by renal denervation for drug-resistant hypertension: a new ABPM analysis of SYMPLICITY HTN-3 and HTN-Japan. Journal of Hypertension 2015;33 Suppl 1:e52.

Kario K, Bhatt D, Townsend R, Flack J, Negoita M, Oparil S, Bakris G. Potential reduction in office and nocturnal blood pressure after renal denervation in patients with obstructive sleep apnea: A subgroup analysis of SYMPLICITY HTN-3. European Heart Journal 2015;36:186.

Kario K, Bhatt DL, Brar S, Cohen SA, Fahy M, Bakris GL. Effect of catheter-based renal denervation on morning and nocturnal blood pressure: insights from SYMPLICITY HTN-3 and SYMPLICITY HTN-Japan. Hypertension 2015;66:1130-7.

NCT01418261. Renal denervation in patients with uncontrolled hypertension (SYMPLICITY HTN-3). clinicaltrials.gov/ct2/show/ NCT01418261 (first received 2011).

Pekarskiy S, Baev A, Mordovin V, Sitkova E, Semke G, Ripp T, et al. Failure of renal denervation in SYMPLICITY HTN-3 is a predictable result of anatomically inadequate operative technique and not the true limitations of the technology. Journal of Hypertension 2015;33 Suppl 1:e108.

\section{Warchol 2014 \{published data only\}}

NCT01366625. Renal denervation in patients with resistant hypertension and obstructive sleep apnea. clinicaltrials.gov/ ct2/show/NCT01366625 (first received 2011).
* Warchol E, Prejbisz A, Kadziela J, Florczak E, Kabat M, Sliwinski $P$, et al. The impact of renal sympathetic denervation on office and ambulatory blood pressure levels in patients with true resistant hypertension and obstructive sleep apnea: the interim analysis. European Heart Journal 2014;35:231.

Xiang 2014 \{published data only\}

* Xiang C, Xu YL, Liu ZJ, Yan PY, Gao JQ, Gao BL. Effects of catheter-based renal sympathetic denervation at different segments of the renal artery on resistant hypertension. Experimental and Clinical Cardiology 2014;20:145-56.

Xu YL, Liu ZJ, Jin HG, Gao JQ, Yan PY, Zhang WQ, et al. Effect of ablation sites in catheter-based renal sympathetic denervation on anti-hypertension results in patients with resistant hypertension. Academic Journal of Second Military Medical University 2014;35:191-4.

\section{References to studies excluded from this review}

Ahmed 2012b \{published data only\}

Ahmed H, Neuzil P, Skoda J, Petru J, Sediva L, Schejbalova M, et al. Renal sympathetic denervation using an irrigated radiofrequency ablation catheter for the management of drugresistant hypertension. JACC. Cardiovascular Interventions 2012;5:758-65.

\section{Ahmed 2013 \{published data only\}}

Ahmed H, Miller MA, Dukkipati SR, Cammack S, Koruth JS, Gangireddy S, et al. Adjunctive renal sympathetic denervation to modify hypertension as upstream therapy in the treatment of atrial fibrillation (H-FIB) study: clinical background and study design. Journal of Cardiovascular Electrophysiology 2013;24:503-9.

\section{Brandt 2012 \{published data only\}}

Brandt MC, Mahfoud F, Reda S, Schirmer SH, Erdmann E, Bohm M, et al. Renal sympathetic denervation reduces left ventricular hypertrophy and improves cardiac function in patients with resistant hypertension. Journal of the American College of Cardiology 2012;59:901-9.

\section{Brandt 2012a \{published data only\}}

Brandt MC, Reda S, Mahfoud F, Lenski M, Bohm M, Hoppe UC. Effects of renal sympathetic denervation on arterial stiffness and central hemodynamics in patients with resistant hypertension. Journal of the American College of Cardiology 2012;60:1956-65.

\section{ChiCTR-ONC-12002901 \{published data only\}}

ChiCTR-ONC-12002901. Transcatheter renal denervation for patients with resistant hypertension. www.chictr.org.cn 2012.

\section{ChiCTR-ONC-13003231 \{published data only\}}

ChiCTR-ONC-13003231. Noninvasive renal sympathetic denervation by high-intensity focused ultrasound (HIFU) in patients with refractory hypertension. www.chictr.org.cn 2013. 
ChiCTR-TNC-12002900 \{published data only\}

ChiCTR-TNC-12002900. A comprehensive assessment of the cardiovascular effects of transcatheter renal sympathetic nerve denervation. www.chictr.org.cn 2012.

\section{EnligHTN III \{published data only\}}

NCT01836146. International first-in-human study of the EnligHTN generation 2 system in patients with drug-resistant uncontrolled hypertension (EnligHTN III). clinicaltrials.gov/ct2/ show/NCT01836146 (first received 2013).

\section{Esler 2013 \{published data only\}}

Esler M, Krum H, Schlaich M, Bohm M, Schmieder RE. Renal denervation via catheter-based delivery of radiofrequency energy significantly reduces blood pressure in subjects with severe treatment-resistant hypertension: long-term results from the SYMPLICITY-HTN clinical trials. Circulation 2013;128(S22):A14747.

\section{Ewen 2014 \{published data only\}}

Ewen S, Mahfoud F, Linz D, Poss J, Cremers B, Kindermann I, et al. Effects of renal sympathetic denervation on exercise blood pressure, heart rate, and capacity in patients with resistant hypertension. Hypertension 2014;63:839-45.

\section{FadI Elmula 2013 \{published data only\}}

Fadl Elmula FE, Hoffmann P, Fossum E, Brekke M, Gjonnaess E, Hjornholm U, et al. Renal sympathetic denervation in patients with treatment-resistant hypertension after witnessed intake of medication before qualifying ambulatory blood pressure. Hypertension 2013;62:526-32.

\section{Grassi 2015 \{published data only\}}

Grassi G, Seravalle G, Brambilla G, Trabattoni D, Cuspidi C, Corso $\mathrm{R}$, et al. Blood pressure responses to renal denervation precede and are independent of the sympathetic and baroreflex effects. Hypertension 2015;65:1206-16.

\section{Hering 2013 \{published data only\}}

Hering D, Lambert EA, Marusic P, Ika-Sari C, Walton AS, Krum H, et al. Renal nerve ablation reduces augmentation index in patients with resistant hypertension. Journal of Hypertension 2013;31:1893-900

\section{Kandzari 2016 \{published data only\}}

Kandzari DE, Kario K, Mahfoud F, Cohen SA, Pilcher G, Pocock S, et al. The SPYRAL-HTN global clinical trial program: rationale and design for studies of renal denervation in the absence (SPYRAL-HTN OFF-MED) and presence (SPYRAL-HTN ON-MED) of antihypertensive medications. American Heart Journal 2016;171:82-91.

\section{Karbasi-Afshar 2013 \{published data only\}}

Karbasi-Afshar R, Noroozian R, Shahmari A, Saburi A. The effect of renal arteries sympathectomy on refractory hypertension. Tehran University Medical Journal 2013;71:179-84.

\section{Katholi 2014 \{published data only\}}

Katholi R, Esler M, Krum H, Rocha-Singh K, Schlaich M, Bohm M, et al. Pooled 3-year SYMPLICITY HTN-1 and SYMPLICITY HTN-2 results and diabetes subgroup analysis. JACC: Cardiovascular Interventions 2014;1:S50.

\section{Kjeldsen 2014 \{published data only\}}

Kjeldsen SE, Narkiewicz K, Oparil S, Hedner T. Renal denervation in treatment-resistant hypertension: Oslo RDN, SYMPLICITY HTN-3 and INSPIRED randomized trials. Blood Pressure 2014;23:135-7.

\section{Krum 2014 \{published data only\}}

Krum H, Schlaich MP, Sobotka PA, Bohm M, Mahfoud F, RochaSingh $\mathrm{K}$, et al. Percutaneous renal denervation in patients with treatment-resistant hypertension: final 3-year report of the SYMPLICITY HTN-1 study. Lancet 2014;383:622-9 [Erratum in Lancet. 2014;383(9917):602].

Mahfoud 2011 \{published data only\} Mahfoud F, Schlaich M, Kindermann I, Ukena C, Cremers B, Brandt MC, et al. Effect of renal sympathetic denervation on glucosmetabolism in patients with resistant hypertension. Internist 2011;52:36.

\section{Mahfoud 2011a \{published data only\}}

Mahfoud F, Schlaich M, Kindermann I, Ukena C, Cremers B, Brandt MC, et al. Effect of renal sympathetic denervation on glucose metabolism in patients with resistant hypertension: a pilot study. Circulation 2011;123:1940-6.

\section{Mahfoud 2012 \{published data only\}}

Mahfoud F, Cremers B, Janker J, Link B, Vonend O, Ukena C, et al. Renal hemodynamics and renal function after catheterbased renal sympathetic denervation in patients with resistant hypertension. Hypertension 2012;60:419-24.

Mahfoud 2014 \{published data only\}

Mahfoud F, Urban D, Teller D, Linz D, Stawowy P, Hassel JH, et al. Effect of renal denervation on left ventricular mass and function in patients with resistant hypertension: data from a multi-centre cardiovascular magnetic resonance imaging trial. European Heart Journal 2014;35:2224-31b.

NCT01117025 \{published data only\}

NCT01117025. Combined treatment of resistant hypertension and atrial fibrillation. clinicaltrials.gov/ct2/show/NCT01117025 (first received 2010).

\section{NCT01465724 \{published data only\}}

NCT01465724. Renal sympathetic denervation for treatment of metabolic syndrome associated hypertension (Metabolic Syndrome study). clinicaltrials.gov/ct2/show/NCT01465724 (first received 2013).

\section{NCT01583881 \{published data only\}}

NCT01583881. Renal denervation in patients with heart failure with normal LV ejection fraction. clinicaltrials.gov/ct2/show/ NCT01583881 (first received 2014).

NCT01631370 \{published data only\}

NCT01631370. The effects of renal sympathetic denervation on insulin sensitivity in patients with resistant essential 
hypertension. clinicaltrials.gov/ct2/show/NCT01631370 (first received 2012).

\section{NCT01635998 \{published data only\}}

NCT01635998. Adjunctive renal sympathetic denervation to modify hypertension as upstream therapy in the treatment of atrial fibrillation. clinicaltrials.gov/ct2/show/NCT01635998 (first received 2012).

\section{NCT01687725 \{published data only\}}

NCT01687725. Renal denervation in treatment resistant hypertension. clinicaltrials.gov/ct2/show/NCT01687725 (first received 2012).

\section{NCT01733901 \{published data only\}}

NCT01733901. Renal sympathetic denervation as secondary prevention for patients after percutaneous coronary intervention. clinicaltrials.gov/ct2/show/NCT01733901 (first received 2012).

\section{NCT01814111 \{published data only\}}

NCT01814111. Safety and effectiveness study of percutaneous catheter-based sympathetic denervation of the renal arteries in patients with hypertension and paroxysmal atrial fibrillation. clinicaltrials.gov/ct2/show/NCT01814111 (first received 2012).

NCT01848314 \{published data only\}

NCT01848314. The effect of renal denervation on renal flow in humans. clinicaltrials.gov/ct2/show/NCT01848314 (first received 2013).

\section{NCT01873352 \{published data only\}}

NCT01873352. Renal artery denervation in addition to catheter ablation to eliminate atrial fibrillation. clinicaltrials.gov/ct2/ show/NCT01873352 (first received 2013).

\section{NCT01888315 \{published data only\}}

NCT01888315. Influence of catheter-based renal denervation in diseases with increased sympathetic activity. clinicaltrials.gov/ ct2/show/NCT01888315 (first received 2012).

NCT01897545 \{published data only\}

NCT01897545. The role of renal denervation in improving outcomes of catheter ablation in patients with atrial fibrillation and arterial hypertension. clinicaltrials.gov/ct2/show/ NCT01897545 (first received 2012).

NCT01901549 \{published data only\}

NCT01901549. Renal denervation in patients after acute coronary syndrome. clinicaltrials.gov/ct2/show/NCT01901549 (first received 2013).

\section{NCT01907828 \{published data only\}}

NCT01907828. A feasibility study to evaluate the effect of concomitant renal denervation and cardiac ablation on AF recurrence. clinicaltrials.gov/ct2/show/NCT01907828 (first received 2013)
NCT01932450 \{published data only\}

NCT01932450. Radiofrequency ablation for ADPKD blood pressure and disease progression control. clinicaltrials.gov/ct2/ show/NCT01932450 (first received 2013).

NCT02016573 \{published data only\}

NCT02016573. Renal denervation for uncontrolled hypertension. clinicaltrials.gov/ct2/show/NCT02016573 (first received 2013)

NCT02057224 \{published data only\}

NCT02057224. Metabolic and cardiovascular effects of renal denervation. clinicaltrials.gov/ct2/show/NCT02057224 (first received 2014).

\section{NCT02115100 \{published data only\}}

NCT02115100. Treatment of atrial fibrillation in patients by pulmonary vein isolation, renal artery denervation or both. clinicaltrials.gov/ct2/show/NCT02115100 (first received 2014).

NCT02115230 \{published data only\}

NCT02115230. Transcatheter renal denervation in heart failure with normal left ventricular ejection fraction - a safety and efficacy study of irrigated radiofrequency catheter. clinicaltrials.gov/ct2/show/NCT02115230 (first received 2014).

NCT02155790 \{published data only\}

NCT02155790. The Peregrine study: a safety and performance study of renal denervation. clinicaltrials.gov/ct2/show/ NCT02155790 (first received 2014).

NCT02164435 \{published data only\}

NCT02164435. Effects of renal sympathetic denervation on the cardiac and renal functions in patients with drug-resistant hypertension through MRI evaluation (RDN). clinicaltrials.gov/ ct2/show/NCT02164435 (first received 2014).

NCT02272920 \{published data only\}

NCT02272920. PCl and renal denervation in hypertensive patients with acute coronary syndromes. clinicaltrials.gov/ct2/ show/NCT02272920 (first received 2014).

NCT02559882 \{published data only\}

NCT02559882. Testing effectiveness of renal denervation in patients with therapy-resistant hypertension. clinicaltrials.gov/ ct2/show/NCT02559882 (first received 2015).

Pokushalov 2012 \{published data only\}

Pokushalov E, Romanov A, Artyomenko S, Turov A, Shirokova N, Karaskov A. Renal denervation and pulmonary vein isolation in patients with drug resistant hypertension and symptomatic atrial fibrillation. European Heart Journal 2012;33:382.

Pokushalov 2012a \{published data only\}

Pokushalov E, Romanov A, Artyomenko S, Turov A, Shirokova N, Karaskov A. Renal denervation and pulmonary vein isolation in patients with drug resistant hypertension and symptomatic atrial fibrillation. Heart Rhythm 2012;1:S172. 
Pokushalov 2012b \{published data only\}

Pokushalov E, Romanov A, Corbucci G, Artyomenko S, Baranova $\mathrm{V}$, Turov A, et al. A randomized comparison of pulmonary vein isolation with versus without concomitant renal artery denervation in patients with refractory symptomatic atrial fibrillation and resistant hypertension. Journal of the American College of Cardiology 2012;60:1163-70.

\section{Pokushalov 2014 \{published data only\}}

Pokushalov E, Romanov A, Katritsis D, Artyomenko S, Bayramova $S$, Losik $D$, et al. The role of renal denervation in improving outcomes of catheter ablation in patients with atrial fibrillation and moderate resistant or resistant hypertension. Journal of the American College of Cardiology 2014;1:A280.

Pokushalov 2014a \{published data only\}

Pokushalov E, Romanov A, Katritsis D, Artyomenko S, Bayramova S, Losik D, et al. Renal denervation for improving outcomes of catheter ablation in patients with atrial fibrillation and hypertension: early experience. European Heart Journal 2014;35:434-5.

\section{Pokushalov 2014b \{published data only\}}

Pokushalov E, Romanov A, Katritsis DG, Artyomenko S, Bayramova S, Losik D, et al. Renal denervation for improving outcomes of catheter ablation in patients with atrial fibrillation and hypertension: early experience. Heart Rhythm 2014;11:1131-8.

\section{RADIANCE-HTN \{published data only\}}

NCT02649426. A study of the ReCor Medical Paradise system in clinical hypertension (RADIANCE-HTN). clinicaltrials.gov/ct2/ show/NCT02649426 (first received 2016).

\section{RAPID \{published data only\}}

NCT01520506. Rapid renal sympathetic denervation for resistant hypertension (RAPID). clinicaltrials.gov/ct2/show/ NCT01520506 (first received 2012).

\section{$\operatorname{ReD}\{$ published data only\}}

NCT01355055. Sympathetic activity and renal denervation (ReD). clinicaltrials.gov/ct2/show/NCT01355055 (first received 2011).

\section{REDUCE HTN:REINFORCE \{published data only\}}

NCT02392351. Renal denervation using the Vessix Renal Denervation system for the treatment of hypertension (REDUCE HTN:REINFORCE). clinicaltrials.gov/ct2/show/NCT02392351 (first received 2015).

\section{RNS-NTR 4384 \{published data only\}}

NTR4384. Feasibility of electrical mapping and stimulation of renal arteries in patients undergoing renal denervation. Netherlands Trial Register. http://www.trialregister.nl 2014.

\section{RSDAH \{published data only\}}

NCT02642445. Renal sympathetic denervation from the adventitia on hypertension (RSDAH). clinicaltrials.gov/ct2/ show/NCT02642445 (first received 2015).
Shipman 2014 \{published data only\}

Shipman KE. A controlled trial of renal denervation for resistant hypertension. Annals of Clinical Biochemistry 2014;51:621.

SPYRAL HTN-OFF MED \{published data only\}

NCT02439749. Global clinical study of renal denervation with the SYMPLICITY SPYRAL ${ }^{\mathrm{TM}}$ multi-electrode renal denervation system in patients with uncontrolled hypertension in the absence of antihypertensive medications (SPYRAL HTN-OFF MED). clinicaltrials.gov/ct2/show/NCT02439749 2015.

\section{SPYRAL HTN-ON MED \{published data only\}}

NCT02439775. Global clinical study of renal denervation with the SYMPLICITY SPYRAL ${ }^{\mathrm{TM}}$ multi-electrode renal denervation system in patients with uncontrolled hypertension on standard medical therapy (SPYRAL HTN-ON MED). clinicaltrials.gov/ct2/ show/NCT02439775 2015

\section{SYMPLICITY 2011 \{published data only\}}

SYMPLICITY HTN Investigators. Catheter-based renal sympathetic denervation for resistant hypertension: durability of blood pressure reduction out to 24 months. Hypertension 2011:57:911-7.

\section{SYMPLICITY AF \{published data only\}}

NCT02064764. Renal nerve denervation in patients with hypertension and paroxysmal and persistent atrial fibrillation (SYMPLICITY AF). clinicaltrials.gov/ct2/show/NCT02064764 2014.

\section{UMIN000012020 \{published data only\}}

UMIN000012020. Study of renal sympathetic denervation with radiofrequency ablation catheter for resistant essential hypertension. UMIN Clinical Trial Registry http://umin.ac.jp 2013.

\section{Wage 2015 \{published data only\}}

Wage R, Patel H, Smith GC, Keegan J, Gatehouse P, Vassiliou V, et al. The utility of magnetic resonance imaging in a trial to assess the effect of renal denervation in heart failure with preserved ejection fraction. Journal of Cardiovascular Magnetic Resonance 2015;17(S1):T7.

\section{WAVE IV \{published data only\}}

NCT02029885. Sham controlled study of renal denervation for subjects with uncontrolled hypertension (WAVE IV). clinicaltrials.gov/ct2/show/NCT02029885 2014.

Wave VI \{published data only\}

NCT02480517. Wave VI feasibility study: Phase II randomized sham controlled study of renal denervation for untreated Stage I and II hypertension. clinicaltrials.gov/ct2/show/NCT02480517 2015.

\section{Witkowski 2011 \{published data only\}}

Witkowski A, Prejbisz A, Florczak E, Kadziela J, Sliwinski P, Bielen $P$, et al. Effects of renal sympathetic denervation on blood pressure, sleep apnea course, and glycemic control in patients with resistant hypertension and sleep apnea. Hypertension 2011;58:559-65. 
Yin 2013 \{published data only\}

Yin Y, Chen W, Ling Z, Xu Y, Liu Z, Su L, et al. Preliminary effects of renal sympathetic denervation with saline irrigated catheter on systolic function in patients with heart failure a feasibility report from the swan-HF pilot study. Circulation 2013;128(S22):A17684.

\section{Zhang 2014 \{published data only\}}

Zhang ZH, Yang K, Jiang FL, Zeng LX, Jiang WH, Wang XY. The effects of catheter-based radiofrequency renal denervation on renal function and renal artery structure in patients with resistant hypertension. Journal of Clinical Hypertension 2014;16:599-605.

\section{References to ongoing studies}

ALLEGRO-HTN \{published data only\}

NCT01874470. Renal denervation by Allegro system in patients with resistant hypertension. clinicaltrials.gov/ct2/show/ NCT01874470 (first received 2013).

\section{DENERVHTA \{published data only\}}

NCT02039492. Sympathetic renal denervation versus increment of pharmacological treatment in resistant arterial hypertension. clinicaltrials.gov/ct2/show/NCT02039492 (first received 2012).

\section{DEPART \{published data only\}}

NCT01522430. Denervation of renal sympathetic activity and hypertension study. clinicaltrials.gov/ct2/show/NCT01522430 (first received 2012).

\section{EnligHTN IV \{published data only\}}

NCT01903187. Multi-center, randomized, single-blind, sham controlled clinical investigation of renal denervation for uncontrolled hypertension. clinicaltrials.gov/ct2/show/ NCT01903187 (first received 2013.

\section{ENSURE \{published data only\}}

NCT02102126. Effect of renal denervation on arterial stiffness and haemodynamics in patients with uncontrolled hypertension (ENSURE). clinicaltrials.gov/ct2/show/ NCT02102126 (first received 2014).

\section{INSPIRED \{published data only\}}

* Jin Y, Jacobs L, Baelen M, Thijs L, Renkin J, Hammer F, et al. Rationale and design of the investigator-steered project on intravascular renal denervation for management of drugresistant hypertension (INSPiRED) trial. Blood Pressure 2014;23:138-46.

Jin Y, Jocobs L, Hammer F, Renkin J, Persu A, Staessen JA. Rationale and design of the investigator-steered project on intravascular renal denervation for management of drugresistant hypertension (INSPiRED) trial. Journal of the American Society of Hypertension 2014;8(S4):e71.

NCT01505010. Investigator-steered project on intravascular renal denervation for management of drug-resistant hypertension (INSPIRED). clinicaltrials.gov/ct2/show/ NCT01505010 (first received 2012).
KPS \{published data only\}

NCT02002585. Renal protection using sympathetic denervation in patients with chronic kidney disease (Kidney protection study - KPS Study). clinicaltrials.gov/ct2/show/NCT02002585 (first received 2013)

\section{NCT01848275 \{published data only\}}

NCT01848275. Full length versus proximal renal arteries ablation. clinicaltrials.gov/ct2/show/NCT01848275 (first received 2011)

\section{NCT01918111 \{published data only\}}

NCT01918111. Effects of renal denervation for resistant hypertension on exercise diastolic function and regression of atherosclerosis and the evaluation of new methods predicting a successful renal sympathetic denervation (RENEWAL-EXERCISE, -REGRESS, and -PREDICT trial From RENEWAL RDN Registry). clinicaltrials.gov/ct2/show/NCT01918111 (first received 2013).

\section{NCT01968785 \{published data only\}}

NCT01968785. Renal denervation in patients with uncontrolled blood pressure. clinicaltrials.gov/ct2/show/NCT01968785 (first received 2013).

\section{NCT02021019 \{published data only\}}

NCT02021019. Renal denervation to improve outcomes in patients with end-stage renal disease. clinicaltrials.gov/ct2/ show/NCT02021019 (first received 2014).

\section{NCT02346045 \{published data only\}}

NCT02346045. Effect of renal denervation in end stage renal disease with resistant hypertension. clinicaltrials.gov/ct2/show/ NCT02346045 (first received 2014).

\section{NCT02444442 \{published data only\}}

NCT02444442. The Australian SHAM controlled clinical trial of renal denervation in patients with resistant hypertension (AUSHAM RDN-01). clinicaltrials.gov/ct2/show/NCT02444442 (first received 2015).

\section{NCT02608632 \{published data only\}}

NCT02608632. High frequency guided renal artery denervation for improving outcome of renal ablation procedure. clinicaltrials.gov/ct2/show/NCT02608632 (first received 2015).

\section{NCT02667912 \{published data only\}}

NCT02667912. Distal renal denervation. clinicaltrials.gov/ct2/ show/NCT02667912 (first received 2016).

\section{NTR3444 \{published data only\}}

NTR3444. Endovascular renal sympathetic denervation versus spironolactone in treatment-resistant hypertension: a randomized, multicentric study (RRSS trial). www.trialregister.nl/trialreg/admin/rctview.asp?TC=3444 (first received 2012).

\section{PaCE \{published data only\}}

NCT01895140. A study of renal denervation in patients with treatment resistant hypertension. clinicaltrials.gov/ct2/show/ NCT01895140 (first received 2013) 
RAPID II \{published data only\}

NCT01939392. Rapid renal sympathetic denervation for resistant hypertension using the OneShot renal denervation system II (RAPID II). clinicaltrials.gov/ct2/show/NCT01939392 (first received 2013).

RDNP-2012-01 \{published data only\}

NCT01865240. Renal denervation for resistant hypertension. clinicaltrials.gov/ct2/show/NCT01865240 (first received 2013).

\section{RENO \{published data only\}}

NCT01617551. Effect of renal denervation on no-mediated regulation of salt and water excretion, vasoactive hormones and tubular transport proteins in patients with resistant hypertension (RENO). clinicaltrials.gov/ct2/show/NCT01617551 (first received 2012).

\section{RENSYMPIS \{published data only\}}

NCT01785732. Renal sympathetic denervation and insulin sensitivity (RENSYMPIS study). clinicaltrials.gov/ct2/show/ NCT01785732 (first received 2013).

\section{ReSET-2 \{published data only\}}

NCT01762488. Renal denervation in treatment resistant hypertension, a double-blind randomized controlled trial (ReSET-2). clinicaltrials.gov/ct2/show/NCT01762488 (first received 2013).

\section{RSD4CKD \{published data only\}}

NCT01737138. Safety and effectiveness study of percutaneous catheter-based renal sympathetic denervation in patients with chronic kidney disease and resistant hypertension. clinicaltrials.gov/ct2/show/NCT01737138 (first received 2012).

\section{RSDforAF \{published data only\}}

NCT01713270. Safety and effectiveness study of percutaneous catheter-based renal sympathetic denervation in patients with drug-resistant hypertension and symptomatic atrial fibrillation. clinicaltrials.gov/ct2/show/NCT01713270 (first received 2012).

* Qiu M, Yin Y, Shan Q. Renal sympathetic denervation versus antiarrhythmic drugs for drug-resistant hypertension and symptomatic atrial fibrillation (RSDforAF) trial: study protocol for a randomized controlled trial. Trials 2013;14:168.

\section{SYMPATHY \{published data only\}}

NCT01850901. Renal sympathetic denervation as a new treatment for therapy resistant hypertension - a multicenter randomized controlled trial. clinicaltrials.gov/ct2/show/ NCT01850901 (first received 2013).

* Vink EE, De Beus E, De Jager RL, Voskuil M, Spiering W, Vonken EJ, et al. The effect of renal denervation added to standard pharmacologic treatment versus standard pharmacologic treatment alone in patients with resistant hypertension: rationale and design of the SYMPATHY trial. American Heart Journal 2014;167:308-14.e3.
SYMPLICITY HTN-4 \{published data only\}

NCT01972139. Renal denervation in patients with uncontrolled hypertension - SYMPLICITY HTN-4. clinicaltrials.gov/ct2/show/ NCT01972139 (first received 2013).

\section{Additional references}

\section{Booth 2015}

Booth LC, Nishi EE, Yao ST, Ramchandra R, Lambert GW, Schlaich MP, et al. Reinnervation following catheter-based radiofrequency renal denervation. Experimental Physiology 2015;100(5):485-90.

\section{Calhoun 2008}

Calhoun DA, Jones D, Textor S, Goff DC, Murphy TP, Toto RD, et al. Resistant hypertension: diagnosis, evaluation, and treatment: a scientific statement from the American Heart Association Professional Education Committee of the Council for High Blood Pressure Research. Circulation 2008;117(25):e510-26.

\section{Davis 2013}

Davis MI, Filion KB, Zhang D, Eisenberg MJ, Afilalo J, Schiffrin EL, et al. Effectiveness of renal denervation therapy for resistant hypertension: a systematic review and meta-analysis. Journal of the American College of Cardiology 2013;16(3):231-41.

\section{Esler 2015}

Esler M. Renal denervation: not as easy as it looks. Science Translational Medicine 2015;7(285):285fs18.

\section{Fadl Elmula 2015}

Fadl Elmula FE, Jin Y, Yang WY, Thijs L, Lu YC, Larstorp AC, et al. Meta-analysis of randomized controlled trials of renal denervation in treatment-resistant hypertension. Blood Pressure 2015;24(5):263-74.

\section{GRADEpro GDT 2015 [Computer program]}

Hamilton: McMaster University (developed by Evidence Prime, Inc.). Gradepro GDT. GRADEpro Guideline Development Tool [www.guidelinedevelopment.org]. Hamilton: McMaster University (developed by Evidence Prime, Inc.), 2015.

\section{Guyatt 2008}

Guyatt GH, Oxman AD, Vist GE, Kunz R, Falck-Ytter Y, AlonsoCoello P, Schünemann HJ, GRADE Working Group. GRADE: an emerging consensus on rating quality of evidence and strength of recommendations.. BMJ 2008;336(7650):924-6.

\section{Higgins 2003}

Higgins JP, Thompson SG, Deeks JJ, Altman DG. Measuring inconsistency in meta-analyses. BMJ 2003;327(7414):557-60.

\section{Higgins 2011}

Higgins JPT, Green S (editors). Cochrane Handbook for Systematic Reviews of Interventions Version 5.1.0 (updated March 2011). The Cochrane Collaboration, 2011. Available from www.handbook.cochrane.org. 


\section{Huan 2013}

Huan Y, Cohen DL. Renal denervation: a potential new treatment for severe hypertension. Clinical Cardiology 2013;36(1):10-4.

\section{Judd 2014}

Judd E, Calhoun DA. Apparent and true resistant hypertension: definition, prevalence and outcomes. Journal of Human Hypertension 2014;28(8):463-8. [DOI: 10.1038/jhh.2013.140]

\section{Kandzari 2015}

Kandzari DE, Bhatt DL, Brar S, Devireddy CM, Esler M, Fahy M, et al. Predictors of blood pressure response in the SYMPLICITY HTN-3 trial. European Heart Journal 2015;36(4):219-27.

\section{Leong 2014}

Leong KT, Walton A, Krum H. Renal sympathetic denervation for the treatment of refractory hypertension. Annual Review of Medicine 2014;65:349-65.

\section{Myat 2012}

Myat A, Redwood SR, Qureshi AC, Spertus JA, Williams B. Resistant hypertension. BMJ 2012;345:e7473.

\section{Nakagawa 2013a}

Nakagawa T, Hasegawa Y, Uekawa K, Ma M, Katayama T, Sueta $\mathrm{D}$, et al. Renal denervation prevents stroke and brain injury via attenuation of oxidative stress in hypertensive rats. Journal of the American Heart Association 2013;2(5):e000375.

\section{Nakagawa 2013b}

Katayama T, Sueta D, Kataoka K, Hasegawa Y, Koibuchi N, Toyama K, et al. Long-term renal denervation normalizes disrupted blood pressure circadian rhythm and ameliorates cardiovascular injury in a rat model of metabolic syndrome. Journal of the American Heart Association 2013;2 (4):e000197.

\section{RevMan 2014 [Computer program]}

Nordic Cochrane Centre, The Cochrane Collaboration. Review Manager (RevMan). Version 5.3. Copenhagen: Nordic Cochrane Centre, The Cochrane Collaboration, 2014.

\section{Sakakura 2014}

Sakakura K, Ladich E, Cheng Q, Otsuka F, Yahagi K, Fowler DR, et al. Anatomic assessment of sympathetic peri-arterial renal nerves in man. Journal of the American College of Cardiology 2014;64(7):635-43.

* Indicates the major publication for the study

\section{CHARACTERISTICS OF STUDIES}

Characteristics of included studies [ordered by study ID]

\section{DENER-HTN 2015}

\begin{tabular}{|c|c|}
\hline Methods & $\begin{array}{l}\text { - } \text { Study type: parallel, RCT } \\
\text { - } \text { Country: France } \\
\text { - } \quad \text { Setting: University }\end{array}$ \\
\hline Participants & 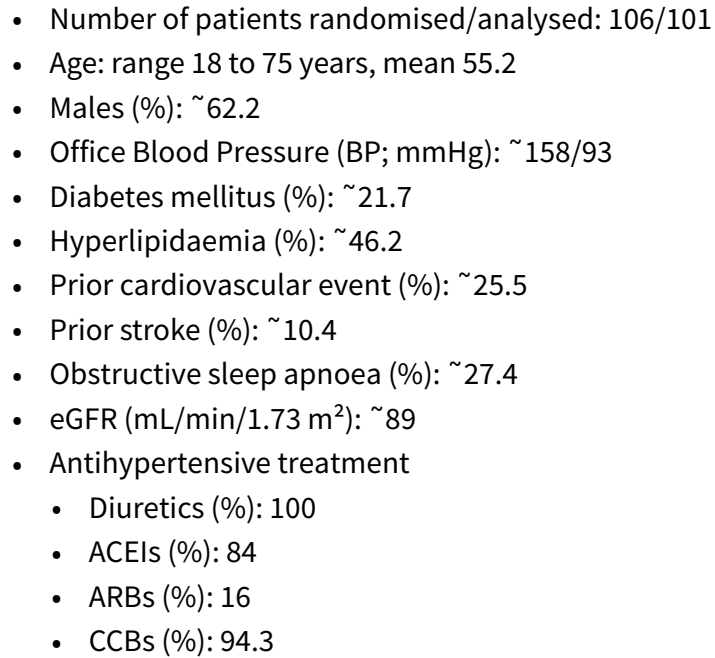 \\
\hline
\end{tabular}

Exclusion criteria: secondary hypertension, eGFR $<40 \mathrm{~mL} / \mathrm{min} / 1.73 \mathrm{~m}^{2}$, history of severe cardiovascular disease or stroke in the previous three months, history of contraindication or intolerance to the study drugs, type 1 diabetes mellitus, brachial circumference $>42 \mathrm{~cm}$, atrial fibrillation, unsuitable renal artery anatomy (accessory renal arteries $>3 \mathrm{~mm}$ in diameter, main renal artery $<4 \mathrm{~mm}$ in diameter or $<20 \mathrm{~mm}$ in length, renal artery stenosis $>30 \%$, prior renal artery intervention or kidney length $<$ 
DENER-HTN 2015 (Continued)

$90 \mathrm{~mm}$ ) ruled out by computed tomography angiogram, magnetic resonance angiogram or renal angiogram

- Treatment group: $\mathrm{N}=48$, renal denervation plus standardised stepped-care antihypertensive treat-
ment (SSAHT)
- Control group: $\mathrm{N}=53$, standardised stepped-care antihypertensive treatment (SSAHT) alone
- Renal denervation procedure: Ablation done with the single electrode radiofrequency Symplicity
catheter. A series of four to six ablations per renal artery were performed.
- SSAHT: Initial standardised triple therapy (indapamide $1.5 \mathrm{mg}$, ramipril $10 \mathrm{mg}$ or irbesartan $300 \mathrm{mg}$,
and amlodipine $10 \mathrm{mg}$ daily) spironolactone $25 \mathrm{mg}$ per day, bisoprolol $10 \mathrm{mg}$ per day, prazosin $5 \mathrm{mg}$
per day, and rilmenidine $1 \mathrm{mg}$ per day
- Follow-up: up to 6 months

Outcomes

- Day-time ambulatory blood pressure monitoring (ABPM)

- 24-hour ABPM

- Office and home ABPM

- Proportion of patients with controlled blood pressure

- estimated Glomerular Filtration Rate (eGFR)

- Adverse events

Notes Modified intention-to-treat and per-protocol analyses performed

\section{Risk of bias}

\begin{tabular}{|c|c|c|}
\hline Bias & Authors' judgement & Support for judgement \\
\hline $\begin{array}{l}\text { Random sequence genera- } \\
\text { tion (selection bias) }\end{array}$ & Low risk & $\begin{array}{l}\text { quote: "The randomisation sequence was generated by computer and strat- } \\
\text { ified by centres using randomised blocks of small size and permutation of } \\
\text { treatments within each block" }\end{array}$ \\
\hline $\begin{array}{l}\text { Allocation concealment } \\
\text { (selection bias) }\end{array}$ & Unclear risk & not specified \\
\hline $\begin{array}{l}\text { Blinding of participants } \\
\text { and personnel (perfor- } \\
\text { mance bias) } \\
\text { All outcomes }\end{array}$ & High risk & open label \\
\hline $\begin{array}{l}\text { Blinding of outcome as- } \\
\text { sessment (detection bias) } \\
\text { All outcomes }\end{array}$ & Low risk & blinded outcome assessors \\
\hline $\begin{array}{l}\text { Incomplete outcome data } \\
\text { (attrition bias) } \\
\text { All outcomes }\end{array}$ & Low risk & $\begin{array}{l}5 / 48(10 \%) \text { drop-outs in treatment group (three lost to follow-up and two with } \\
\text { missing ABPM). A modified intention-to-treat analysis was performed }\end{array}$ \\
\hline $\begin{array}{l}\text { Selective reporting (re- } \\
\text { porting bias) }\end{array}$ & Low risk & all the pre-specified outcomes have been reported \\
\hline Other bias & Low risk & $\begin{array}{l}\text { The funder of the study (French Ministry of Health) had no role in study design, } \\
\text { data collection, data analysis, data interpretation, or writing of the report }\end{array}$ \\
\hline
\end{tabular}

\section{Desch 2015}

Methods - Study type: parallel, RCT


Desch 2015 (Continued)

- Country: Germany

- Setting: University

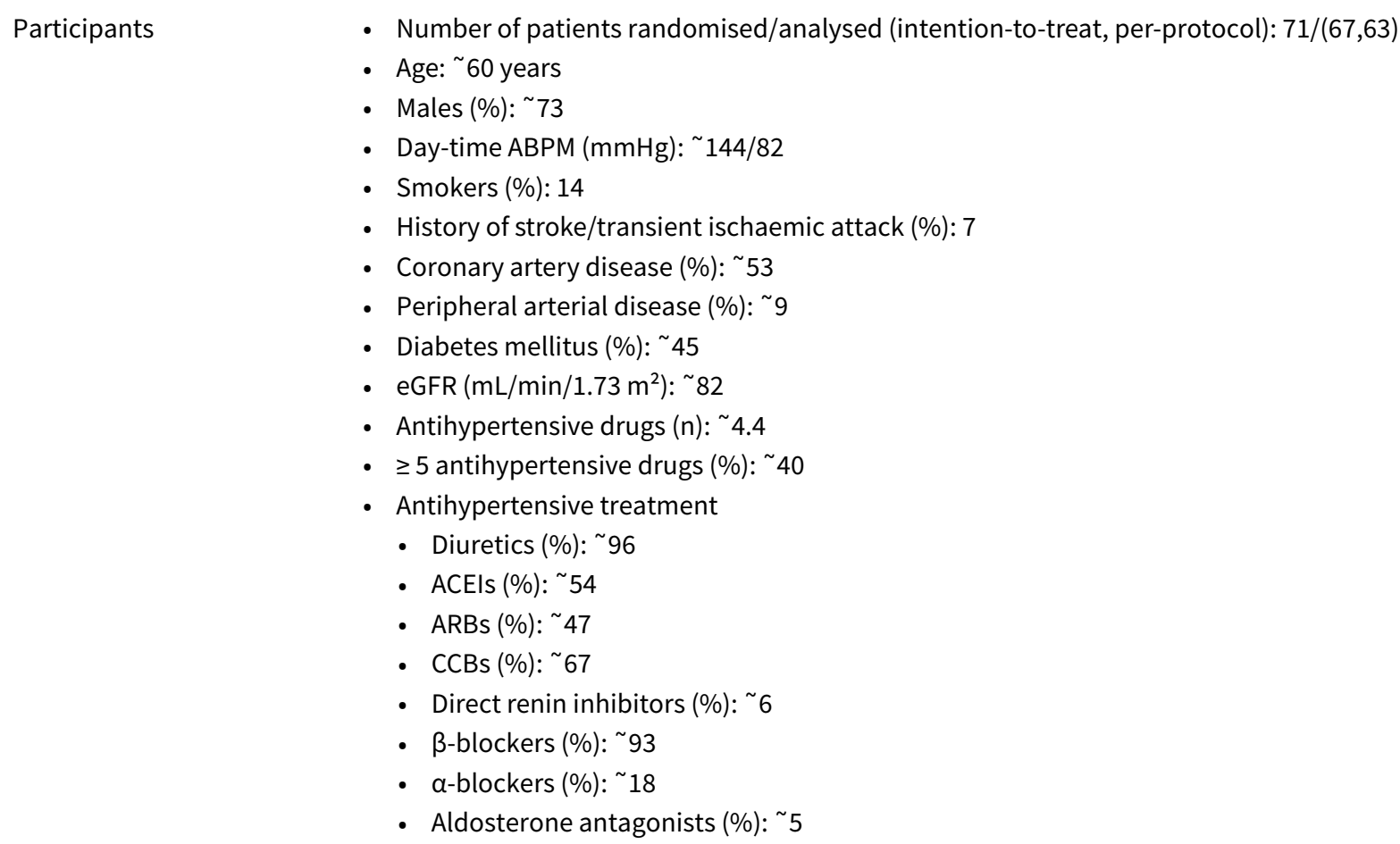

Exclusion criteria: mean day-time systolic BP on 24-hour ABPM $<135$ and $>149 \mathrm{mmHg}$ or mean daytime diastolic $\mathrm{BP}<90$ and $>94 \mathrm{mmHg}$, unsuitable anatomy for renal denervation, severe renal artery stenosis, eGFR $<45 \mathrm{~mL} / \mathrm{min} / 1.73 \mathrm{~m}^{2}$, change in BP medication in the 4 weeks preceding randomisation, unwillingness to adhere to unchanging BP medication during the study period of 6 months, unstable angina pectoris, myocardial infarction within 6 months prior to randomisation, planned surgery or cardiovascular intervention within 6 months after randomisation, severe heart valve disease, pregnancy, and severe comorbidities with limited life expectancy

- Control group: $\mathrm{N}=36$, sham procedure

- Renal denervation procedure: Ablation done with the Symplicity Flex catheter. Four to 6 ablation runs of 2 minutes for each renal artery were delivered circumferentially to the renal artery wall from distal to proximal

- Sham procedure: Angiography of the renal arteries and a simulated renal denervation procedure with 4 to 6 sham runs for each renal artery guided by 2-minute acoustic signals similar to those of the Symplicity generator

- Follow-up: up to 6 months

\begin{tabular}{ll}
\hline Outcomes & 24-hour BP in the intention-to-treat population \\
- 24 -hour BP in the per-protocol population \\
- Adverse events \\
- All-cause death
\end{tabular}

Notes

Intention-to-treat and per-protocol analyses performed

\section{Risk of bias}


Desch 2015 (Continued)

$\begin{array}{ll}\begin{array}{l}\text { Random sequence genera- } \\ \text { tion (selection bias) }\end{array} & \text { quote: "Patients were assigned to the treatment groups by simple randomisa- } \\ & \text { tion, in a 1:1 ratio, via an internet-based system using a computer-generated } \\ & \text { list of random numbers" }\end{array}$

\begin{tabular}{|c|c|c|}
\hline $\begin{array}{l}\text { Allocation concealment } \\
\text { (selection bias) }\end{array}$ & Unclear risk & not specified \\
\hline $\begin{array}{l}\text { Blinding of participants } \\
\text { and personnel (perfor- } \\
\text { mance bias) } \\
\text { All outcomes }\end{array}$ & Low risk & single blind \\
\hline $\begin{array}{l}\text { Blinding of outcome as- } \\
\text { sessment (detection bias) } \\
\text { All outcomes }\end{array}$ & Low risk & $\begin{array}{l}\text { all investigators (including personnel responsible for BP assessment) were } \\
\text { blinded to treatment assignment }\end{array}$ \\
\hline $\begin{array}{l}\text { Incomplete outcome data } \\
\text { (attrition bias) } \\
\text { All outcomes }\end{array}$ & Low risk & $\begin{array}{l}8 / 71(11 \%) \text { drop-outs ( } 6 \text { in RD and } 2 \text { in sham procedure); intention-to-treat and } \\
\text { per-protocol analyses performed }\end{array}$ \\
\hline $\begin{array}{l}\text { Selective reporting (re- } \\
\text { porting bias) }\end{array}$ & Low risk & all the pre-specified outcomes have been reported \\
\hline Other bias & Unclear risk & no apparent other sources of bias \\
\hline
\end{tabular}

Franzen 2012

\begin{tabular}{|c|c|}
\hline Methods & $\begin{array}{l}\text { - Study type: parallel, RCT } \\
\text { - Country: Germany } \\
\text { - Setting: Hospital }\end{array}$ \\
\hline Participants & $\begin{array}{l}\text { - Number of patients randomised/analysed: } 27 / 27 \\
\text { - Age: range } 18 \text { to } 82 \text { years, mean } 63 \\
\text { - Systolic BP (mmHg): > } 150 \\
\text { - Antihypertensive drugs }(\mathrm{n}): \sim 4.7\end{array}$ \\
\hline Interventions & $\begin{array}{l}\text { - Treatment group: } \mathrm{N}=21 \\
\text { - Control group: } \mathrm{N}=6 \\
\text { - Follow-up: up to } 6 \text { months }\end{array}$ \\
\hline Outcomes & $\begin{array}{l}\text { - Peripheral systolic BP } \\
\text { - Central systolic BP } \\
\text { - Pulse wave velocity (PWV) } \\
\text { - Aortic stiffness parameters }\end{array}$ \\
\hline
\end{tabular}

Notes

study in abstract version only. Unclear if patients were truly randomised (quote: "21 patients were randomised to PRD. 6 patients served as controls")

\section{Risk of bias}

\begin{tabular}{lll}
\hline Bias & Authors' judgement & Support for judgement \\
\hline $\begin{array}{l}\text { Random sequence genera- } \\
\text { tion (selection bias) }\end{array}$ & Unclear risk & not specified \\
\hline
\end{tabular}


Franzen 2012 (Continued)

\begin{tabular}{lll}
$\begin{array}{l}\text { Allocation concealment } \\
\text { (selection bias) }\end{array}$ & Unclear risk & not specified \\
\hline $\begin{array}{l}\text { Blinding of participants } \\
\text { and personnel (perfor- }\end{array}$ & Unclear risk & not specified \\
mance bias) & & \\
All outcomes & &
\end{tabular}

\begin{tabular}{lll}
\hline $\begin{array}{l}\text { Blinding of outcome as- } \\
\text { sessment (detection bias) } \\
\text { All outcomes }\end{array}$ & Unclear risk & not specified \\
\hline $\begin{array}{l}\text { Incomplete outcome data } \\
\begin{array}{l}\text { (attrition bias) } \\
\text { All outcomes }\end{array}\end{array}$ & Unclear risk & not specified \\
\hline $\begin{array}{l}\text { Selective reporting (re- } \\
\text { porting bias) }\end{array}$ & Unclear risk & not specified \\
\hline Other bias & Unclear risk & not specified \\
\hline
\end{tabular}

\section{HTN-JAPAN 2015}

\begin{tabular}{ll}
\hline Methods & Study type: parallel, RCT \\
& - Country: Japan \\
& - Setting: University and Hospital \\
\hline
\end{tabular}

\section{Participants}

- Number of patients randomised/analysed: $41 / 41$

- Age: range 20 to 80 years, mean: $~ 58$

- Males (\%): 76

- Office systolic BP (mmHg): 180

- 24-h mean systolic ABPM (mmHg): 164

- type 2 diabetes mellitus (\%): 50

- Hypercholesterolemia (\%): 32

- Prior stroke (\%): 17

- Obstructive sleep apnoea (\%): 10

- $\operatorname{egFR}\left(\mathrm{mL} / \mathrm{min} / 1.73 \mathrm{~m}^{2}\right): \geq 45$

- Antihypertensive drugs (n): 4.9

- Antihypertensive treatment

- Diuretics (\%): 100

- ACEIS (\%): 12

- $\operatorname{ARBs}(\%): \sim 98$

- $\operatorname{CCBs}(\%): \sim 95$

- Direct renin inhibitors (\%): 0

- $\beta$-blockers (\%): 75

- a-blockers (\%): 33

- Aldosterone antagonist (\%): 41

Exclusion criteria: Main renal arteries $<4 \mathrm{~mm}$ in diameter or $<20 \mathrm{~mm}$ treatable length, multiple renal arteries, renal artery stenosis $>50 \%$ or renal artery aneurysm in either renal artery, history of prior renal artery intervention including balloon angioplasty or stenting and unilateral (functional or morphological) kidney, > 1 inpatient hospitalisation for hypertensive crisis not related to non-adherence to 
HTN-JAPAN 2015 (Continued)

medication within the previous year, type 1 diabetes mellitus and $\geq 1$ episodes of orthostatic hypotension not related to medication changes, secondary hypertension

\begin{tabular}{ll}
\hline Interventions & Treatment group: $\mathrm{N}=22$, Renal denervation plus antihypertensive medications \\
- & Control group: $\mathrm{N}=19$, antihypertensive medications alone \\
- & Renal denervation procedure: Ablation done with the Symplicity ${ }^{\mathrm{TM}}$ RDN system (Medtronic, Santa \\
& Rosa, CA, USA). Four to 6 ablation runs of 120 sec for each renal artery were delivered circumferentially \\
& to the renal artery wall from distal to proximal \\
- & Follow-up: up to 6 months \\
\hline Outcomes & Change in office BP \\
- Change in 24 -hour ABPM and home BP \\
- Incidence of major adverse events (composite of 1-month all-cause mortality, end stage renal disease, \\
significant embolic event resulting in end-organ damage, renal artery dissection or perforation requir- \\
ing intervention, vascular complications, hospitalisation for hypertensive crisis or new renal artery \\
stenosis $>70 \%$ confirmed on angiography within 6 months after randomisation)
\end{tabular}

Notes

\section{Risk of bias}

\begin{tabular}{|c|c|c|}
\hline Bias & Authors' judgement & Support for judgement \\
\hline $\begin{array}{l}\text { Random sequence genera- } \\
\text { tion (selection bias) }\end{array}$ & Unclear risk & not specified \\
\hline $\begin{array}{l}\text { Allocation concealment } \\
\text { (selection bias) }\end{array}$ & Unclear risk & not specified \\
\hline $\begin{array}{l}\text { Blinding of participants } \\
\text { and personnel (perfor- } \\
\text { mance bias) } \\
\text { All outcomes }\end{array}$ & High risk & open label \\
\hline $\begin{array}{l}\text { Blinding of outcome as- } \\
\text { sessment (detection bias) } \\
\text { All outcomes }\end{array}$ & Unclear risk & not specified \\
\hline $\begin{array}{l}\text { Incomplete outcome data } \\
\text { (attrition bias) } \\
\text { All outcomes }\end{array}$ & Low risk & No drop-outs. Intention-to-treat analysis performed \\
\hline $\begin{array}{l}\text { Selective reporting (re- } \\
\text { porting bias) }\end{array}$ & Low risk & all the pre-specified outcomes have been reported \\
\hline Other bias & High risk & $\begin{array}{l}\text { Honoraria from Medtronic. Involvement of Medtronic in data collection and } \\
\text { statistical analyses }\end{array}$ \\
\hline
\end{tabular}

\section{Oslo RDN 2014}

\begin{tabular}{ll}
\hline Methods & - Study type: parallel, RCT \\
& - Country: Norway \\
& - Setting: University \\
\hline Participants & - Number of patients randomised/analysed: $19 / 19$
\end{tabular}


Oslo RDN 2014 (Continued)

- Age: range 37 to 70 years, mean 60

- Males (\%): 89

- Office BP (mmHg): $158 / 90$

- Diabetes mellitus (\%): 26

- Coronary artery disease (\%): 35

- Left ventricular hypertrophy (\%): 58

- Peripheral arteriosclerosis (\%): 5

- Previous stroke (\%): 10

- Hypercholesterolaemia (\%): 31

- Microalbuminuria (\%): 37

- Cystatin C (mg/L): 1.0

- Antihypertensive drugs (n): 5.1

- Antihypertensive treatment

- Diuretics (\%): 100

- ACEIs/ARBs (\%): 100

- $\operatorname{CCBs}(\%): \sim 80$

- Direct renin inhibitors (\%): 10

- $\beta$-blockers (\%): 73

- $\alpha$-blockers (\%): 37

- Aldosterone antagonist (\%): 47

Exclusion criteria: secondary and spurious hypertension, known primary hyperaldosteronism not adequately treated, eGFR $<45 \mathrm{~mL} / \mathrm{min} / 1.73 \mathrm{~m}^{2}$, urine albumin/creatinine ratio $>50 \mathrm{mg} / \mathrm{mmol}$, type 1 diabetes mellitus, stenotic valvular heart disease, myocardial infarction, unstable angina, or CVA in the prior 6 months, haemodynamically or anatomically significant renal artery abnormalities or stenosis > $50 \%$ or prior renal artery intervention, known primary pulmonary hypertension, known pheochromocytoma, Cushing's disease, coarctation of the aorta, hyperthyroidism or hyperparathyroidism

- Control group: $\mathrm{N}=10$, drug-adjusted treatment

- Renal denervation procedure: renal denervation performed using a 6 French guide Symplicity catheter system. On average 8 (range 6 to 11) radiofrequency ablations were applied per renal artery

- Follow-up: up to 6 months

$\begin{array}{ll}\text { Outcomes } & \text { 24-hour ABPM } \\ \text { - Office BP } & \text { Day-time ABPM } \\ \text { - Normalization of haemodynamics: cardiac index, heart rate, stroke systemic vascular resistance in- } \\ \text { dex, pulse wave velocity (PWV), and central blood pressure } \\ \text { - Adverse events }\end{array}$

\section{Notes}

\section{Risk of bias}

\begin{tabular}{lll}
\hline Bias & Authors' judgement & Support for judgement \\
\hline $\begin{array}{l}\text { Random sequence genera- } \\
\text { tion (selection bias) }\end{array}$ & Low risk & quote: "randomisation performed using a permuted block randomisation list" \\
\hline $\begin{array}{l}\text { Allocation concealment } \\
\text { (selection bias) }\end{array}$ & Low risk & $\begin{array}{l}\text { quote: "A hospital employee opened a sealed envelope arranged in a fixed or- } \\
\text { der" }\end{array}$ \\
\hline
\end{tabular}


Oslo RDN 2014 (Continued)

Blinding of participants High risk open label
and personnel (perfor-
mance bias)
All outcomes

All outcomes

\begin{tabular}{lll}
\hline $\begin{array}{l}\text { Blinding of outcome as- } \\
\text { sessment (detection bias) } \\
\text { All outcomes }\end{array}$ & High risk & open label \\
\hline $\begin{array}{l}\text { Incomplete outcome data } \\
\text { (attrition bias) }\end{array}$ & Low risk & no drop-outs \\
All outcomes & &
\end{tabular}

\begin{tabular}{lll}
\hline $\begin{array}{l}\text { Selective reporting (re- } \\
\text { porting bias) }\end{array}$ & High risk & some pre-specified outcomes were not reported \\
\hline Other bias & Unclear risk & $\begin{array}{l}\text { Honoraria from Medtronic and Hemo Sapiens. Involvement of industry in data } \\
\text { collection and analyses not specified }\end{array}$ \\
\hline
\end{tabular}

\section{Prague-15 2016}

\begin{tabular}{|c|c|}
\hline Methods & $\begin{array}{l}\text { - Study type: parallel, RCT } \\
\text { - Country: Czech Republic } \\
\text { - Setting: University }\end{array}$ \\
\hline Participants & 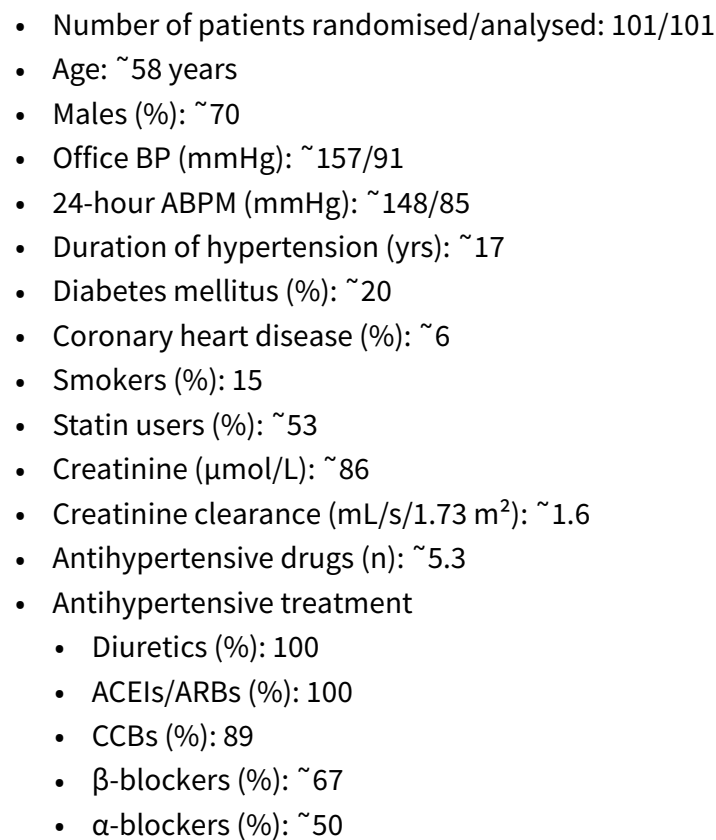 \\
\hline
\end{tabular}

Exclusion criteria: secondary hypertension, non-compliance with medical treatment, presence of any chronic renal disease (serum creatinine $>200 \mu \mathrm{mol} / \mathrm{L}$ ), pregnancy, history of myocardial infarction or stroke in the previous 6 months, presence of severe valvular stenotic disease, anatomical abnormality or a variant structure of either renal artery, including aneurysm, stenosis, a reference diameter $<4 \mathrm{~mm}$ and a length $<20 \mathrm{~mm}$, an increased bleeding risk (thrombocytopenia $<50.000$ platelets $/ \mu \mathrm{L}$ and an INR $>$ 1.5) 
- Control group: $\mathrm{N}=50$, intensified pharmacological treatment including spironolactone (PHAR)

- Renal denervation procedure: ablation involved $\geq 4$ to 6 applications of low-power (8 W) radiofrequency energy to each renal artery using the Symplicity renal denervation system

- Follow-up: up to 12 months

\begin{tabular}{ll}
\hline Outcomes & 24-hour ABPM \\
& Office BP \\
& - Average number of antihypertensive drugs used after 6 months \\
& Renal function (serum creatinine, creatinine clearance) \\
\hline Notes & \\
\hline
\end{tabular}

\section{Risk of bias}

\begin{tabular}{|c|c|c|}
\hline Bias & Authors' judgement & Support for judgement \\
\hline $\begin{array}{l}\text { Random sequence genera- } \\
\text { tion (selection bias) }\end{array}$ & Unclear risk & Not specified \\
\hline $\begin{array}{l}\text { Allocation concealment } \\
\text { (selection bias) }\end{array}$ & Unclear risk & Not specified \\
\hline $\begin{array}{l}\text { Blinding of participants } \\
\text { and personnel (perfor- } \\
\text { mance bias) } \\
\text { All outcomes }\end{array}$ & High risk & Open label \\
\hline $\begin{array}{l}\text { Blinding of outcome as- } \\
\text { sessment (detection bias) } \\
\text { All outcomes }\end{array}$ & High risk & Open label \\
\hline $\begin{array}{l}\text { Incomplete outcome data } \\
\text { (attrition bias) } \\
\text { All outcomes }\end{array}$ & Low risk & $\begin{array}{l}\text { 38/101 (37\%) drop-outs ( } 7 \text { in RD and } 31 \text { in PHAR group); intention-to-treat and } \\
\text { per-protocol analyses performed }\end{array}$ \\
\hline $\begin{array}{l}\text { Selective reporting (re- } \\
\text { porting bias) }\end{array}$ & Low risk & All the pre-specified outcomes have been reported \\
\hline Other bias & Unclear risk & No apparent other sources of bias \\
\hline
\end{tabular}

\section{RELIEF 2012}

\begin{tabular}{ll}
\hline Methods & Study type: parallel, RCT \\
& - Country: Czech Republic \\
& - Setting: Hospital \\
\hline Participants & Number of patients randomised/analysed: $23 / 23$ \\
& - Age: range 18 to 85 years \\
- Office $B P(\mathrm{mmH}): \geq 140$ & - Exclusion criteria: secondary hypertension, eGFR $<45 \mathrm{~mL} / \mathrm{min} / 1.73 \mathrm{~m}^{2}$, type 1 diabetes mellitus, ren- \\
& ovascular abnormalities (renal artery stenosis, previous renal artery stenting or angioplasty), life ex- \\
& pectancy $<1$ year for any medical condition
\end{tabular}


RELIEF 2012 (Continued)

- Control group: $\mathrm{N}=12$, sham procedure

- Renal denervation procedure: ablation performed with an off-the-shelf saline-irrigated radiofrequency ablation catheter

- Sham procedure: angiography of the renal arteries (manipulation of catheter within the renal arteries without the delivery of any energy)

- Follow-up: up to 3 months

\begin{tabular}{ll}
\hline Outcomes & $\cdot 24$-hour ABPM \\
& $\cdot$ Office BP \\
& $\cdot$ Serum creatinine
\end{tabular}

Notes

\section{Risk of bias}

\begin{tabular}{lll}
\hline Bias & Authors' judgement & Support for judgement \\
\hline $\begin{array}{l}\text { Random sequence genera- } \\
\text { tion (selection bias) }\end{array}$ & Unclear risk & Not specified \\
\hline $\begin{array}{l}\text { Allocation concealment } \\
\text { (selection bias) }\end{array}$ & Unclear risk & Not specified \\
\hline $\begin{array}{l}\text { Blinding of participants } \\
\text { and personnel (perfor- } \\
\text { mance bias) } \\
\text { All outcomes }\end{array}$ & Low risk & Single-blind \\
\hline $\begin{array}{l}\text { Blinding of outcome as- } \\
\text { sessment (detection bias) } \\
\text { All outcomes }\end{array}$ & Unclear risk & Not specified \\
\hline $\begin{array}{l}\text { Incomplete outcome data } \\
\text { (attrition bias) } \\
\text { All outcomes }\end{array}$ & Unclear risk & Not specified \\
\hline $\begin{array}{l}\text { Selective reporting (re- } \\
\text { porting bias) }\end{array}$ & High risk & Some pre-specified outcomes were not reported \\
\hline \begin{tabular}{l} 
Other bias \\
\hline
\end{tabular} & Unclear risk & No apparent other sources of bias \\
\hline
\end{tabular}

\section{ReSET 2015}

\begin{tabular}{ll}
\hline Methods & Study type: parallel, RCT \\
- Country: Denmark & - Setting: University and Hospital \\
\hline Participants & - Number of patients randomised/analysed: $69 / 69$ \\
- Age: range 30 to 70 years, mean: $56 \pm 9$ \\
- $24-\mathrm{h}$ systolic ABPM $(\mathrm{mmHg}):$ 159 \\
- eGFR $\left(\mathrm{mL} / \mathrm{min} / 1.73 \mathrm{~m}^{2}\right): \geq 30$ \\
Exclusion criteria: pregnancy, no compliance, heart failure (NYHA 3 to 4), left ventricular ejection frac- \\
tion < $50 \%$. Unstable coronary heart disease, coronary intervention within 6 months, myocardial infarc- \\
tion within 6 months. Claudication. Orthostatic syncope within 6 months, secondary hypertension, per-
\end{tabular}


ReSET 2015 (Continued)

manent atrial fibrillation. significant heart valve disease. Clinically significant abnormal electrolytes, haemoglobin, liver enzymes and TSH. Second and third degree heart block, macroscopic haematuria, proximal significant coronary stenosis, renal artery anatomy not suitable for renal artery ablation (stenosis, diameter $<4 \mathrm{~mm}$, length $<20 \mathrm{~mm}$, multiple renal arteries, severe calcifications)

$\begin{array}{ll}\text { - Tnterventions } & \text { Treatment group: } \mathrm{N}=36 \text {, renal denervation } \\ \text { - Control group: } \mathrm{N}=33 \text {, sham procedure } \\ \text { - Renal denervation procedure: catheter-based renal denervation by applying low power radiofrequen- } \\ \text { cy to the renal artery using the Ardian Medtronic Simplicity catheter. } \\ \text { - Follow-up: up to } 6 \text { months } \\ \text { - } 24 \text {-hour systolic ABPM after 3-month follow-up } \\ \text { - Daytime and night time BP, dipping status, morning BP surge and BP variation } \\ \text { - Coronary flow reserve (LAD), diastolic and systolic ventricular function. Left ventricular hypertrophy. } \\ \text { - Biomarkers of renal sodium excretion } \\ \text { - Pulse wave velocity, augmentation index, central BP estimates } \\ \text { - Decline in eGFR } \geq 25 \% \\ \text { - Forearm minimum vascular resistance }\end{array}$

Notes study in abstract version only

\section{Risk of bias}

\begin{tabular}{|c|c|c|}
\hline Bias & Authors' judgement & Support for judgement \\
\hline $\begin{array}{l}\text { Random sequence genera- } \\
\text { tion (selection bias) }\end{array}$ & Unclear risk & not specified \\
\hline $\begin{array}{l}\text { Allocation concealment } \\
\text { (selection bias) }\end{array}$ & Unclear risk & not specified \\
\hline $\begin{array}{l}\text { Blinding of participants } \\
\text { and personnel (perfor- } \\
\text { mance bias) } \\
\text { All outcomes }\end{array}$ & Low risk & Double-blind \\
\hline
\end{tabular}

\begin{tabular}{lll}
\hline $\begin{array}{l}\text { Blinding of outcome as- } \\
\text { sessment (detection bias) } \\
\text { All outcomes }\end{array}$ & Unclear risk & not specified \\
\hline $\begin{array}{l}\text { Incomplete outcome data } \\
\begin{array}{l}\text { (attrition bias) } \\
\text { All outcomes }\end{array}\end{array}$ & Unclear risk & not specified \\
\hline $\begin{array}{l}\text { Selective reporting (re- } \\
\text { porting bias) }\end{array}$ & High risk & Some pre-specified outcomes were not reported \\
\hline Other bias & Unclear risk & not specified \\
\hline
\end{tabular}

\section{SYMPLICITY HTN-2 2010}

$\begin{array}{ll}\text { Methods } & \text { - Study type: parallel, RCT } \\ & \text { - Country: Multicentre } \\ & \text { Setting: Hospital, University }\end{array}$


SYMPLICITY HTN-2 2010 (Continued)

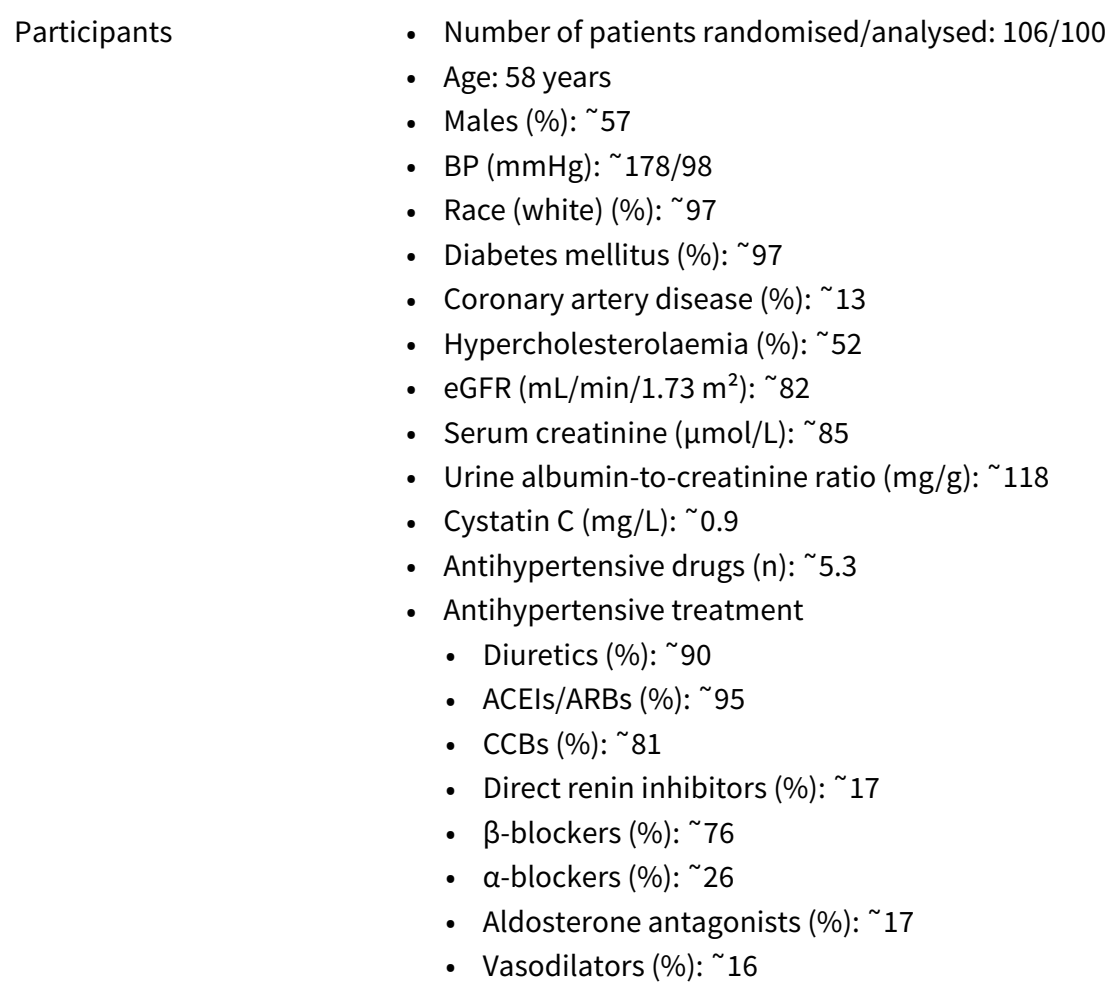

Exclusion criteria: eGFR $<45 \mathrm{~mL} / \mathrm{min} / 1.73 \mathrm{~m}^{2}$, type 1 diabetes mellitus, contraindications to MRI, substantial stenotic valvular heart disease, pregnancy or planned pregnancy during the study, history of myocardial infarction, unstable angina or cerebrovascular accident in the previous 6 months, haemodynamically significant renal artery stenosis, previous renal artery intervention or renal artery anatomy ineligible for treatment ( $<4 \mathrm{~mm}$ diameter, $<20 \mathrm{~mm}$ length or more than one main renal arteries)

$\begin{array}{ll}\text { Interventions } & \text { Treatment group: } \mathrm{N}=52 \text {, bilateral renal denervation plus baseline antihypertensive medications } \\ \text { - } & \text { Control group: } \mathrm{N}=54 \text {, baseline antihypertensive medications } \\ \text { - } & \text { Renal denervation procedure: renal denervation with Symplicity catheter system. Four to six discrete, } \\ & \text { low-power radio frequency treatments were applied along the length of both main renal arteries } \\ \text { - Follow-up: up to } 6 \text { months } & \\ \text { - Office BP } & \text { Short and long-term safety profile: reduction of eGFR }>25 \% \text { or new stenosis }>60 \%, \text { composite car- } \\ \text { diovascular end point (myocardial infarction, sudden cardiac death, new onset heart failure, death } \\ \text { from progressive heart failure, stroke, aortic or lower limb revascularization procedure, lower limb } \\ \text { amputation, death from aortic or peripheral arterial disease, dialysis, death because of renal failure, } \\ \text { hospital admission for hypertensive emergency unrelated to non-adherence or non-persistence with } \\ \text { drugs and hospital admission for atrial fibrillation) }\end{array}$

Notes

\section{Risk of bias}

\begin{tabular}{lll}
\hline Bias & Authors' judgement & Support for judgement \\
\hline $\begin{array}{l}\text { Random sequence genera- } \\
\text { tion (selection bias) }\end{array}$ & Unclear risk & Not specified \\
\hline $\begin{array}{l}\text { Allocation concealment } \\
\text { (selection bias) }\end{array}$ & Low risk & quote: "Randomisation was done with sealed envelopes" \\
\hline
\end{tabular}




\section{SYMPLICITY HTN-2 2010 (Continued)}

$\begin{array}{lll}\text { Blinding of participants } & \text { High risk } & \text { Open label } \\ \text { and personnel (perfor- } & \\ \text { mance bias) } & \\ \text { All outcomes } & \end{array}$

Blinding of outcome as-
sessment (detection bias) $\quad$ Unclear risk Data analysers were not masked to treatment assignment

All outcomes

Incomplete outcome data Low risk (attrition bias)

All outcomes

\begin{tabular}{lll}
\hline $\begin{array}{l}\text { Selective reporting (re- } \\
\text { porting bias) }\end{array}$ & Low risk & All the pre-specified outcomes have been reported \\
\hline Other bias & High risk & Data were monitored, collected, and managed by the sponsor (Ardian) \\
\hline
\end{tabular}

6/100 (6\%) drop-outs (3 in RD and 3 in control group); quote: "all analyses were done with data for all patients at randomisation minus those lost to follow-up"

SYMPLICITY HTN-3 2014

\begin{tabular}{ll}
\hline Methods & - Study type: parallel, RCT \\
& - Country: US \\
& - Setting: Hospital, University
\end{tabular}

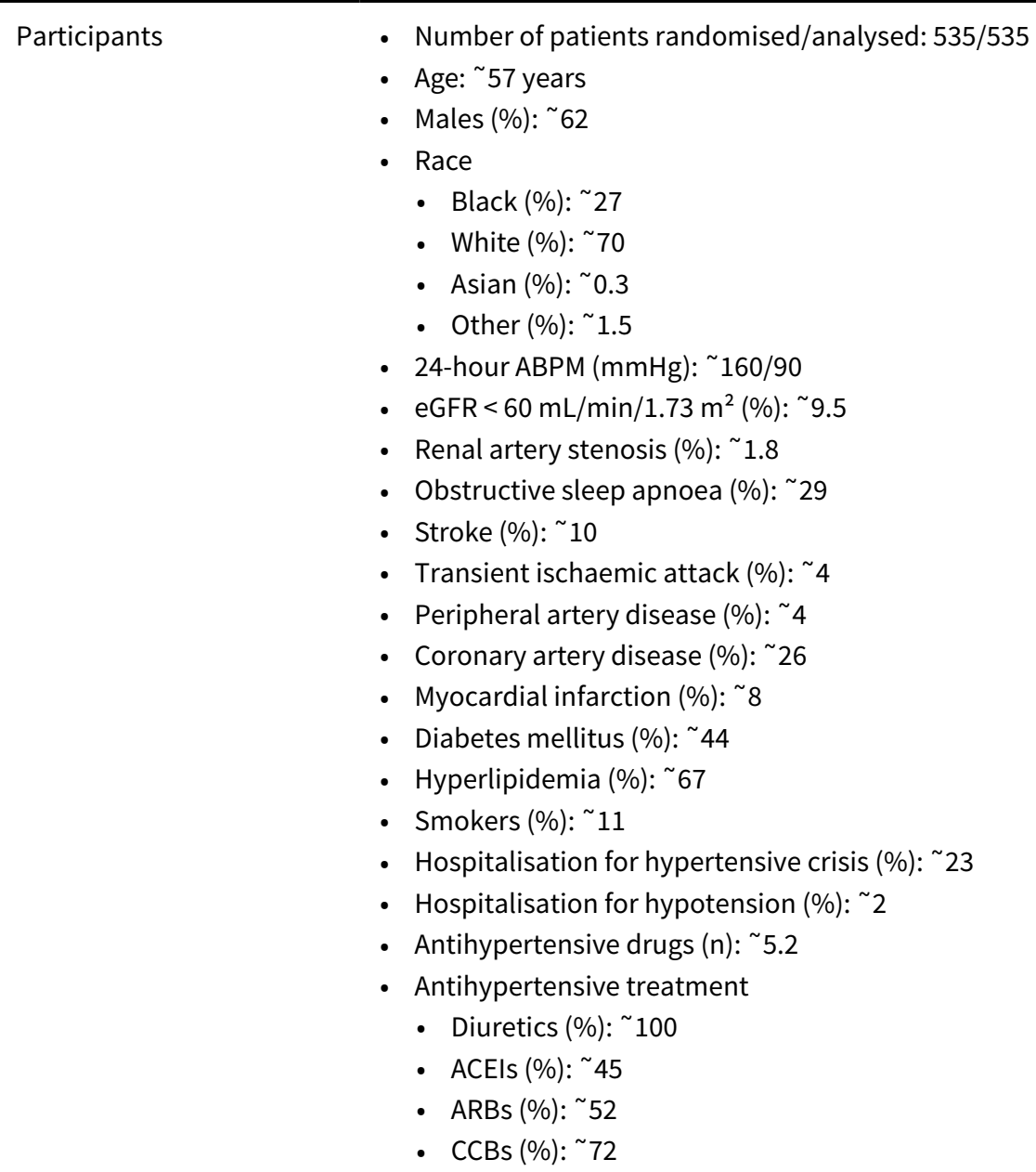


SYMPLICITY HTN-3 2014 (Continued)

- Direct renin inhibitors (\%): 7

- $\beta$-blockers (\%): 86

- a-blockers (\%): 12

- Aldosterone antagonists (\%): 25

Exclusion criteria: secondary causes of hypertension or more than one hospitalisation for hypertensive emergency in the previous year, primary pulmonary hypertension, 24-h ABPM average $\mathrm{SBP}<135$ $\mathrm{mmHg}$, eGFR $<45 \mathrm{~mL} / \mathrm{min} / 1.73 \mathrm{~m}^{2}$, type 1 diabetes mellitus, chronic oxygen support or mechanical ventilation other than nocturnal respiratory support for sleep apnoea, renal artery stenosis $>50 \%$, renal artery aneurysm, prior renal artery intervention, multiple renal arteries, renal artery diameter $<4$ $\mathrm{mm}$ or treatable segment $<20 \mathrm{~mm}$ in length, myocardial infarction, unstable angina pectoris, syncope or a cerebrovascular accident within 6 months of the screening period, history of pheochromocytoma, Cushing's disease, coarctation of the aorta, hyperthyroidism or hyperparathyroidism, pregnancy, nursing or planning to be pregnant

\begin{tabular}{ll}
\hline Interventions & Treatment group: $\mathrm{N}=364$, bilateral renal denervation plus baseline antihypertensive medications \\
- Control group: $\mathrm{N}=171$, sham procedure plus baseline antihypertensive medications \\
- Renal denervation procedure: Four to six ablations of up to 120 seconds delivered to the renal artery \\
wall beginning at the distal end of the artery \\
- Sham procedure: angiography of the renal arteries \\
- Follow-up: up to 6 months \\
- 24 -hour ABPM \\
- Office systolic BP \\
- Day-time and night-time BP \\
- Incidence of major adverse events (composite of: all-cause mortality, end-stage renal disease, signif- \\
icant embolic event resulting in end-organ damage, renal artery perforation or dissection requiring \\
intervention, vascular complications, hospitalisation for hypertensive crisis not related to non-adher- \\
ence with medications or new renal artery stenosis $>70 \%)$
\end{tabular}

Notes

\section{Risk of bias}

\begin{tabular}{lll}
\hline Bias & Authors' judgement & Support for judgement \\
\hline $\begin{array}{l}\text { Random sequence genera- } \\
\text { tion (selection bias) }\end{array}$ & Unclear risk & $\begin{array}{l}\text { quote: "Randomization (2:1 ratio) is performed using an interactive voice re- } \\
\text { sponse system" }\end{array}$ \\
\hline $\begin{array}{l}\text { Allocation concealment } \\
\text { (selection bias) }\end{array}$ & Unclear risk & Not specified \\
\hline $\begin{array}{l}\text { Blinding of participants } \\
\begin{array}{l}\text { and personnel (perfor- } \\
\text { mance bias) }\end{array}\end{array}$ & Low risk \\
All outcomes & & \\
\hline
\end{tabular}

Blinding of outcome as- Low risk sessment (detection bias) All outcomes quote: "Outcome's assessors were blinded to the treatment. Blood pressure assessments were done by blinded, trained personnel".

$\begin{array}{ll}\begin{array}{l}\text { Incomplete outcome data } \\ \text { (attrition bias) }\end{array} & \text { Low risk } \\ \text { All } & \begin{array}{l}16 / 535 \text { (3\%) drop-outs (14 in RD and } 2 \text { in sham procedure); ITT analysis per- } \\ \text { formed }\end{array}\end{array}$

All outcomes 
SYMPLICITY HTN-3 2014 (Continued)
Other bias
High risk
quote: "Data were collected and analysed by the sponsor (Medtronic, Min- neapolis, Minnesota) and independently validated by Harvard Clinical Re- search Institute (Boston, Massachusetts)"

\section{Warchol 2014}

\begin{tabular}{|c|c|}
\hline Methods & $\begin{array}{l}\text { - Study type: parallel, RCT } \\
\text { - Country: Poland } \\
\text { - Setting: Institute of Cardiology }\end{array}$ \\
\hline Participants & $\begin{array}{l}\text { - Number of patients randomised/analysed: } 35 / 35 \\
\text { - Age: range } 32 \text { to } 69 \text { years, mean } 55.4 \pm 7.9 \\
\text { - Males }(\%): 77 \\
\text { - Office BP (mmHg): } \geq 140 / 90 \\
\text { - Obstructive sleep apnoea (apnea/hypopnoea index, AHI): } \geq 15 \text { events/hour } \\
\text { - Exclusion criteria: renal artery abnormalities, eGFR }<60 \mathrm{~mL} / \mathrm{min} \text {, previous TIA, stroke, heart failure, } \\
\text { type } 1 \text { diabetes mellitus, implantable cardioverter defibrillator or pacemaker }\end{array}$ \\
\hline Interventions & $\begin{array}{l}\text { - Treatment group: } \mathrm{N}=19 \text {, renal denervation plus antihypertensive medications } \\
\text { - Control group: } \mathrm{N}=16 \text {, antihypertensive medications alone } \\
\text { - Renal denervation procedure: ablation done using a catheterbased procedure (Symplicity) } \\
\text { - Follow-up: } 3 \text { months }\end{array}$ \\
\hline Outcomes & $\begin{array}{l}\text { - Office BP } \\
\text { - 24-hour, day-time and night-time ABPM } \\
\text { - Responses to renal denervation (sleep apnoea course, metabolic assessment, cardiac changes) }\end{array}$ \\
\hline
\end{tabular}

Notes

\section{Risk of bias}

\begin{tabular}{lll}
\hline Bias & Authors' judgement & Support for judgement \\
\hline $\begin{array}{l}\text { Random sequence genera- } \\
\text { tion (selection bias) }\end{array}$ & Unclear risk & Not specified \\
\hline $\begin{array}{l}\text { Allocation concealment } \\
\text { (selection bias) }\end{array}$ & Unclear risk & Not specified \\
\hline $\begin{array}{l}\text { Blinding of participants } \\
\text { and personnel (perfor- } \\
\text { mance bias) }\end{array}$ & High risk & \\
All outcomes & \\
\hline $\begin{array}{l}\text { Blinding of outcome as- } \\
\text { sessment (detection bias) } \\
\text { All outcomes }\end{array}$ & High risk & Open label \\
\hline $\begin{array}{l}\text { Incomplete outcome data } \\
\text { (attrition bias) } \\
\begin{array}{l}\text { All outcomes } \\
\hline\end{array}\end{array}$ & Low risk & No drop-outs \\
\hline
\end{tabular}


Warchol 2014 (Continued)

Selective reporting (re- Unclear risk $\quad$ Not specified
porting bias)

Other bias Unclear risk No apparent other sources of bias

Xiang 2014

\begin{tabular}{ll}
\hline Methods & Study type: parallel, RCT \\
& - Country: China \\
& - Setting: University
\end{tabular}

\begin{tabular}{|c|c|}
\hline Participants & 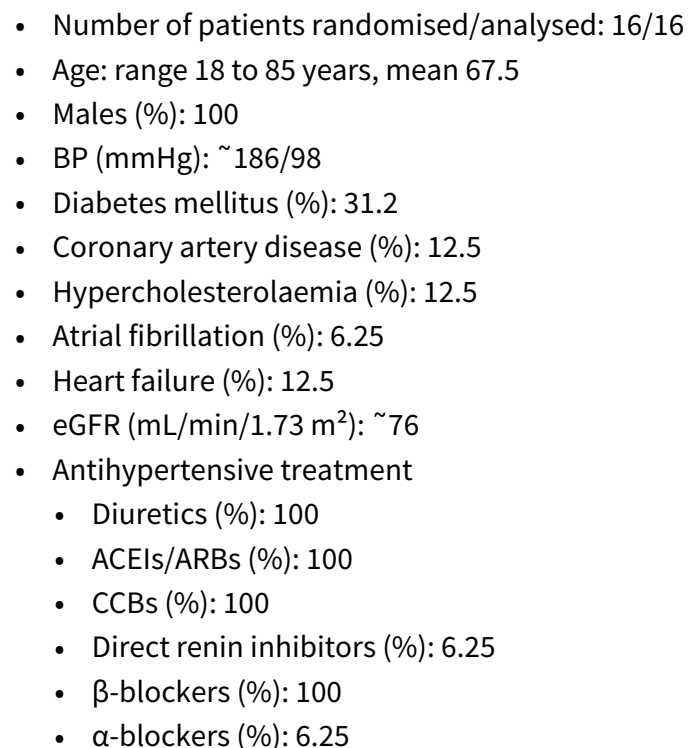 \\
\hline
\end{tabular}

Exclusion criteria: eGFR $<45 \mathrm{~mL} / \mathrm{min} / 1.73 \mathrm{~m}^{2}$, type 1 diabetes mellitus, stenotic valvular heart disease and pregnancy. Renal artery anatomy ineligible for treatment (main renal arteries $<4 \mathrm{~mm}$ in diameter or $<20 \mathrm{~mm}$ in length, abnormality or stenosis in either renal artery, prior renal artery angioplasty or stenting or multiple main renal arteries)

\begin{tabular}{ll} 
Interventions & Treatment group: $\mathrm{N}=8$, proximal ablation \\
- Control group: $\mathrm{N}=8$, whole ablation & Renal denervation procedure: ablation made through a radiofrequency catheter (5 French, IBI-Ther- \\
& apy, St. Jude Medical). Six ablations were performed for the whole ablation group, whereas three ab- \\
& lations at the proximal segment for the proximal ablation group. \\
- Follow-up: up to 6 months & \\
\hline Outcomes & Office BP \\
- Adverse events
\end{tabular}

Notes

\section{Risk of bias}

\begin{tabular}{lll}
\hline Bias & Authors' judgement & Support for judgement \\
\hline $\begin{array}{l}\text { Random sequence genera- } \\
\text { tion (selection bias) }\end{array}$ & Low risk & $\begin{array}{l}\text { quote: "All the patients were randomly divided using a computer algorithm in- } \\
\text { to two groups" }\end{array}$ \\
\hline
\end{tabular}


Xiang 2014 (Continued)

\begin{tabular}{lll}
$\begin{array}{l}\text { Allocation concealment } \\
\text { (selection bias) }\end{array}$ & Unclear risk & not specified \\
\hline $\begin{array}{l}\text { Blinding of participants } \\
\text { and personnel (perfor- }\end{array}$ & High risk & open label \\
mance bias) & & \\
All outcomes & &
\end{tabular}

\begin{tabular}{lll}
\hline $\begin{array}{l}\text { Blinding of outcome as- } \\
\text { sessment (detection bias) } \\
\text { All outcomes }\end{array}$ & High risk & open label \\
\hline $\begin{array}{l}\text { Incomplete outcome data } \\
\begin{array}{l}\text { (attrition bias) } \\
\text { All outcomes }\end{array}\end{array}$ & Low risk & no drop-outs \\
\hline $\begin{array}{l}\text { Selective reporting (re- } \\
\text { porting bias) }\end{array}$ & Low risk & all the pre-specified outcomes have been reported \\
\hline \begin{tabular}{l} 
Other bias \\
\hline
\end{tabular} & Unclear risk & no apparent other sources of bias \\
\hline
\end{tabular}

\section{Legend}

ABPM: ambulatory blood pressure monitoring; ACEi: Angiotensin-converting enzyme inhibitors; ARBs: Angiotensin receptor blockers; BP: blood pressure; CCBs: calcium channel blockers; CVA: cardiovascular; eGFR: estimated glomerular filtration rate; ITT: intention-to-treat; $\mathrm{RCT}$ : randomized controlled trial; RD: renal denervation; SBP: systolic blood pressure.

\section{Characteristics of excluded studies [ordered by study ID]}

\begin{tabular}{|c|c|}
\hline Study & Reason for exclusion \\
\hline Ahmed 2012b & not RCT \\
\hline Ahmed 2013 & wrong population \\
\hline Brandt 2012 & not RCT \\
\hline Brandt 2012a & not RCT \\
\hline ChiCTR-ONC-12002901 & not RCT \\
\hline ChiCTR-ONC-13003231 & wrong intervention \\
\hline ChiCTR-TNC-12002900 & not RCT \\
\hline EnligHTN III & not RCT \\
\hline Esler 2013 & wrong population \\
\hline Ewen 2014 & not RCT \\
\hline Fadl Elmula 2013 & not RCT \\
\hline Grassi 2015 & not RCT \\
\hline Hering 2013 & not RCT \\
\hline
\end{tabular}




\begin{tabular}{|c|c|}
\hline Study & Reason for exclusion \\
\hline Kandzari 2016 & wrong population \\
\hline Karbasi-Afshar 2013 & not RCT \\
\hline Katholi 2014 & wrong population \\
\hline Kjeldsen 2014 & not RCT \\
\hline Krum 2014 & not RCT \\
\hline Mahfoud 2011 & wrong population \\
\hline Mahfoud 2012 & not RCT \\
\hline Mahfoud 2014 & not RCT \\
\hline NCT01117025 & wrong intervention \\
\hline NCT01465724 & not RCT \\
\hline NCT01583881 & wrong population \\
\hline NCT01631370 & not RCT \\
\hline NCT01635998 & wrong population \\
\hline NCT01687725 & not RCT \\
\hline NCT01733901 & wrong population \\
\hline NCT01814111 & wrong population \\
\hline NCT01848314 & not RCT \\
\hline NCT01873352 & wrong population \\
\hline NCT01888315 & not RCT \\
\hline NCT01897545 & wrong intervention \\
\hline NCT01901549 & wrong population \\
\hline NCT01907828 & wrong population \\
\hline NCT01932450 & wrong population \\
\hline NCT02016573 & wrong population \\
\hline NCT02057224 & not RCT \\
\hline NCT02115100 & wrong population \\
\hline NCT02115230 & wrong population \\
\hline
\end{tabular}




\begin{tabular}{|c|c|}
\hline Study & Reason for exclusion \\
\hline NCT02155790 & not RCT \\
\hline NCT02164435 & not RCT \\
\hline NCT02272920 & wrong population \\
\hline NCT02559882 & wrong intervention \\
\hline Pokushalov 2012 & wrong intervention \\
\hline Pokushalov 2012a & wrong intervention \\
\hline Pokushalov 2014 & wrong intervention \\
\hline Pokushalov 2014a & not RCT \\
\hline Pokushalov 2014b & wrong intervention \\
\hline RADIANCE-HTN & wrong population \\
\hline RAPID & not RCT \\
\hline $\operatorname{ReD}$ & not RCT \\
\hline RNS-NTR 4384 & not RCT \\
\hline RSDAH & wrong population \\
\hline Shipman 2014 & not RCT \\
\hline SPYRAL HTN-OFF MED & wrong population \\
\hline SPYRAL HTN-ON MED & wrong population \\
\hline SYMPLICITY 2011 & not RCT \\
\hline SYMPLICITY AF & wrong population \\
\hline UMIN000012020 & not RCT \\
\hline Wage 2015 & wrong outcome \\
\hline WAVE IV & wrong intervention \\
\hline Wave VI & wrong intervention \\
\hline Witkowski 2011 & not RCT \\
\hline Yin 2013 & wrong population \\
\hline Zhang 2014 & not RCT \\
\hline
\end{tabular}


Characteristics of ongoing studies [ordered by study ID]

\section{ALLEGRO-HTN}

\begin{tabular}{|c|c|}
\hline Trial name or title & Renal denervation by Allegro System in patients with resistant hypertension \\
\hline Methods & $\begin{array}{l}\text { - Study type: parallel, RCT } \\
\text { - Country: China } \\
\text { - Setting: Hospital }\end{array}$ \\
\hline Participants & $\begin{array}{l}\text { - Estimated number of patients: } 160 \\
\text { - Age: range } 18 \text { to } 65 \text { years } \\
\text { - Office BP (mmHg): } \geq 160 / 100 \text { (despite stable medication regimen including } 3 \text { or more antihyper- } \\
\text { tensive medications of different classes, including a diuretic) } \\
\text { - ABPM ( } \mathrm{mmHg}): \geq 140 / 90 \\
\text { - eGFR }\left(\mathrm{mL} / \mathrm{min} / 1.73 \mathrm{~m}^{2}\right): \geq 45 \\
\text { Exclusion criteria: pregnancy, type } 1 \text { diabetes mellitus, secondary hypertension. ICD or pacemak- } \\
\text { er, myocardial infarction, unstable angina, syncope, cerebrovascular accident in the previous } 6 \\
\text { months. Intravascular thrombosis or unstable atherosclerotic plaques, significant valvular heart } \\
\text { disease. Renal artery stenosis ( } \geq 50 \% \text { ) or renal artery aneurysm in either renal artery, history of pri- } \\
\text { or renal artery intervention including balloon angioplasty or stenting. Multiple renal arteries where } \\
\text { the main renal artery is estimated to supply }<75 \% \text { of the kidney. Main renal arteries with }<4 \text { mm } \\
\text { diameter or with }<20 \text { mm treatable length (by visual estimation), renal artery abnormalities }\end{array}$ \\
\hline
\end{tabular}

$\begin{array}{ll}\text { Interventions } & \text { Treatment group: renal angiography followed by renal sympathetic denervation } \\ \text { - Control group: renal angiography alone } \\ \text { - Renal denervation procedure: Allegro Renal Denervation System (AngioCare) } \\ \text { - Follow-up: up to } 48 \text { months }\end{array}$

- Change in office SBP from baseline to 6 months
- Change in average 24-hour SBP by ABPM from baseline to 6 months
- Incidence of major adverse events (MAE) at 1 month post-randomisation
- Office SBP and DBP at $1,3,6$ months post-randomisation
- Patient-recorded home systolic blood pressure at $1,3,6$ months post-randomisation
- MAE at 6 -month post-randomisation, including new renal artery stenosis $>60 \%$

\begin{tabular}{ll}
\hline Starting date & May 2013 \\
\hline Contact information & Xiongjing Jiang: jxj103@hotmail.com \\
\hline
\end{tabular}

Notes

\section{DENERVHTA}

\begin{tabular}{ll}
\hline Trial name or title & $\begin{array}{l}\text { Sympathetic renal denervation versus increment of pharmacological treatment in resistant arterial } \\
\text { hypertension }\end{array}$ \\
\hline Methods & - Study type: parallel, RCT \\
& - Setting: Hospital \\
\hline Participants & - Estimated number of patients: 50 \\
& Age: range 18 to 80 years
\end{tabular}


- Office BP $(\mathrm{mmHg}): \geq 140 / 90$ (despite stable medication regimen including 3 or more antihypertensive medications of different classes, including a diuretic)

- $\operatorname{eGFR}\left(\mathrm{mL} / \mathrm{min} / 1.73 \mathrm{~m}^{2}\right): \geq 45$

Exclusion criteria: pregnancy, secondary hypertension, unsuitable anatomy of renal arteries (diameter $<4 \mathrm{~mm}$ and length $<20 \mathrm{~mm}$ ) including significant $(\geq 50 \%$ ) renal arterial stenosis, renal artery stent, single functional kidney, previous nephrectomy, contrast agent allergy, hyperthyroidia, Treatment with an aldosterone receptor blocker (spironolactone, eplerenone), pre-randomization serum potassium $\left(\mathrm{K}^{+}\right)$level $\geq 5.5 \mathrm{mmol} / \mathrm{L}$, significant renal vascular anomalies, significant valvular heart disease, major vascular event (myocardial infarction, unstable angina or cerebrovascular disease) $<6$ months prior to study enrolment

\begin{tabular}{ll}
\hline Interventions & Treatment group: sympathetic renal denervation \\
- Control group: treatment with aldactone & - Renal denervation procedure: radiofrequency catheter-based therapy for renal denervation. \\
& Four-to-six low-power radio frequency treatments along the length of both main renal arteries. \\
- Follow-up: up to 36 months
\end{tabular}

\begin{tabular}{ll}
\hline Outcomes & 24-hour SBP \\
\hline Starting date & September 2012 \\
\hline Contact information & Anna OLiveras, PhD 003493248316287052 @parcdesalutmar.cat \\
\hline Notes & \\
\hline
\end{tabular}

\section{DEPART}

\begin{tabular}{|c|c|}
\hline Trial name or title & Study of catheter-based renal denervation therapy in hypertension (DEPART) \\
\hline Methods & $\begin{array}{l}\text { - Study type: parallel, RCT } \\
\text { - Country: Belgium } \\
\text { - Setting: Hospital }\end{array}$ \\
\hline Participants & $\begin{array}{l}\text { - Estimated number of patients: } 240 \\
\text { - Age: range } 18 \text { to } 85 \text { years } \\
\text { - Office BP }(\mathrm{mmHg}): \geq 135 / 85 \\
\text { - eGFR }\left(\mathrm{mL} / \mathrm{min} / 1.73 \mathrm{~m}^{2}\right): \geq 30 \\
\text { Exclusion criteria: unsuitable anatomy of renal arteries (diameter }<4 \mathrm{~mm} \text { and length }<20 \mathrm{~mm} \text { ) in- } \\
\text { cluding significant }(\geq 50 \%) \text { renal arterial stenosis, renal artery stent or single functional kidney. Se- } \\
\text { condary hypertension, previous nephrectomy, contrast agent allergy, Hyperthyroidia }\end{array}$ \\
\hline Interventions & $\begin{array}{l}\text { - Treatment group: renal angiography followed by renal sympathetic denervation } \\
\text { - Control group: renal angiography alone } \\
\text { - Renal denervation procedure: radiofrequency catheter-based therapy for renal denervation. } \\
\text { Four-to-six low-power radio frequency treatments along the length of both main renal arteries. } \\
\text { - Follow-up: up to } 48 \text { months }\end{array}$ \\
\hline Outcomes & $\begin{array}{l}\text { - 24-hour SBP } \\
\text { - Change in GFR and } 24 \text { h urine sample measure } \\
\text { - Baroreflex sensitivity } \\
\text { - Biological markers of acute kidney injury }\end{array}$ \\
\hline
\end{tabular}


DEPART (Continued)
Starting date
January 2012

Contact information

Contact: ARGACHA Jean Francois, MD Jean.Francois.Argacha@erasme.ulb.ac.be

Notes

\section{EnligHTN IV}

Trial name or title Multi-center, randomized, single-blind, sham controlled clinical investigation of renal denervation for uncontrolled hypertension (EnligHTN IV)

\begin{tabular}{|c|c|}
\hline Methods & $\begin{array}{l}\text { - Study type: parallel, RCT } \\
\text { - Country: US } \\
\text { - Setting: University and Hospital }\end{array}$ \\
\hline Participants & $\begin{array}{l}\text { - Estimated number of patients: } 590 \\
\text { - Age: range } 18 \text { to } 80 \text { years } \\
\text { - Office BP ( } \mathrm{mmHg} \text { ): } \geq 160 \\
\text { - Systolic ABPM } \geq 140 \mathrm{mmHg} \text { (despite stable medication regimen including } 3 \text { or more antihyperten- } \\
\text { sive medications of different classes, including a diuretic) } \\
\left.\text { - eGFR ( } \mathrm{mL} / \mathrm{min} / 1.73 \mathrm{~m}^{2}\right): \geq 45 \\
\text { Exclusion criteria: pregnancy, type } 1 \text { diabetes mellitus, chronic oxygen support or mechanical ven- } \\
\text { tilation, primary pulmonary hypertension. Previous renal denervation, secondary hypertension, } \\
\text { significant renovascular abnormalities. Myocardial infarction, unstable angina pectoris, or cere- } \\
\text { brovascular accident }<180 \text { days prior to enrolment. Blood clotting abnormalities, life expectancy < } \\
12 \text { months. Renal arteries }<4 \text { mm in diameter or }<20 \text { mm in length or multiple renal arteries where } \\
\text { the main renal arteries supply < } 75 \% \text { of the kidney, abdominal aortic aneurysm (AAA), pheochro- } \\
\text { mocytoma, Cushing's disease, coarctation of the aorta, hyperthyroidism and hyperparathyroidism }\end{array}$ \\
\hline Interventions & $\begin{array}{l}\text { - Treatment group: renal denervation } \\
\text { - Control group: sham procedure } \\
\text { - Renal denervation procedure: renal artery ablation with the EnligHTN }{ }^{\mathrm{TM}} \text { Renal Denervation Sys- } \\
\text { tem } \\
\text { - Follow-up: up to } 36 \text { months }\end{array}$ \\
\hline Outcomes & $\begin{array}{l}\text { - Proportion of subjects who experience any major adverse event (MAE) } \\
\text { - Reduction of office systolic BP at } 6 \text { months } \\
\text { - Procedure-related adverse events } \\
\text { - Incidence of achieving } \geq 10 \mathrm{mmHg}, \geq 15 \mathrm{mmHg} \text {, and } \geq 20 \mathrm{mmHg} \text { reductions in office BP } \\
\text { - Reduction in ABPM }\end{array}$ \\
\hline
\end{tabular}

Starting date October 2013

Contact information NA

Notes 


\section{ENSURE}

Trial name or title

Effect of renal denervation on arterial stiffness and haemodynamics in patients with uncontrolled hypertension (ENSURE)

\begin{tabular}{ll}
\hline Methods & Study type: parallel, RCT \\
& - Country: China \\
& - Setting: Hospital \\
\hline Participants & Estimated number of patients: 400 \\
- Age: range 18 to 80 years \\
- Office BP $(\mathrm{mmHg}): \geq 160 / 100$ (despite stable medication regimen including 3 or more antihyper- \\
- tensive medications of different classes, including a diuretic) \\
- ABPM $(\mathrm{mmHg}): \geq 140 / 90$ \\
- eGFR $\left(\mathrm{mL} / \mathrm{min} / 1.73 \mathrm{~m}^{2}\right): \geq 45$
\end{tabular}

Exclusion criteria: pregnancy, type 1 diabetes mellitus, chronic oxygen support or mechanical ventilation, primary pulmonary hypertension, ABPM 24 hour average $\mathrm{SBP}<135 \mathrm{mmHg}$

\begin{tabular}{ll}
\hline Interventions & Treatment group: Renal denervation \\
& - Control group: Baseline anti-hypertensive medications \\
- Renal denervation procedure: MDT-2211 Renal Denervation System & Follow-up: up to 36 months \\
\hline Outcomes & Change in 24-hour ambulatory aortic and brachial blood pressure and blood pressure variability \\
- Incidence of major adverse events through 1 month post-randomisation \\
- Change in asymptomatic organ damages (including electrocardiographically or echocardio- \\
graphically diagnosed left ventricular hypertrophy, carotid intima-media thickness or plaque, mi- \\
croalbuminuria, pulse wave velocity).
\end{tabular}

\begin{tabular}{ll}
\hline Starting date & September 2014 \\
\hline Contact information & Yawei Xu; yizshcn@gmail.com \\
\hline
\end{tabular}

Notes

\section{INSPIRED}

\begin{tabular}{ll}
\hline Trial name or title & $\begin{array}{l}\text { Investigatorsteered project on intravascular renal denervation for management of drugresistant } \\
\text { hypertension (INSPiRED) }\end{array}$ \\
\hline Methods & Study type: parallel, RCT \\
& - Country: Belgium \\
\hline Participants & Setting: University \\
\hline & Estimated number of patients: 240 \\
& - Office $\mathrm{BP}(\mathrm{mmHg}): \geq 140 / 90$ \\
& eGFR ( $\left.\mathrm{mL} / \mathrm{min} / 1.73 \mathrm{~m}^{2}\right): \geq 60$ \\
& Exclusion criteria: pregnancy, secondary hypertension, unsuitable anatomy of renal arteries (diam- \\
eter $<4 \mathrm{~mm}$ and length $<20 \mathrm{~mm}$ ) including significant $(\geq 50 \%$ renal arterial stenosis, renal artery \\
stent or $\mathrm{single}$ functional kidney, isolated systolic or isolated diastolic hypertension, body mass in- \\
dex $\geq 40 \mathrm{~kg} / \mathrm{m}^{2}$, unstable diabetes mellitus, major cardiovascular events within 6 months prior to
\end{tabular}


INSPIRED (Continued)

enrolment, any serious medical condition, alcohol or substance abuse or psychiatric illnesses, patients on the waiting list of elective surgery

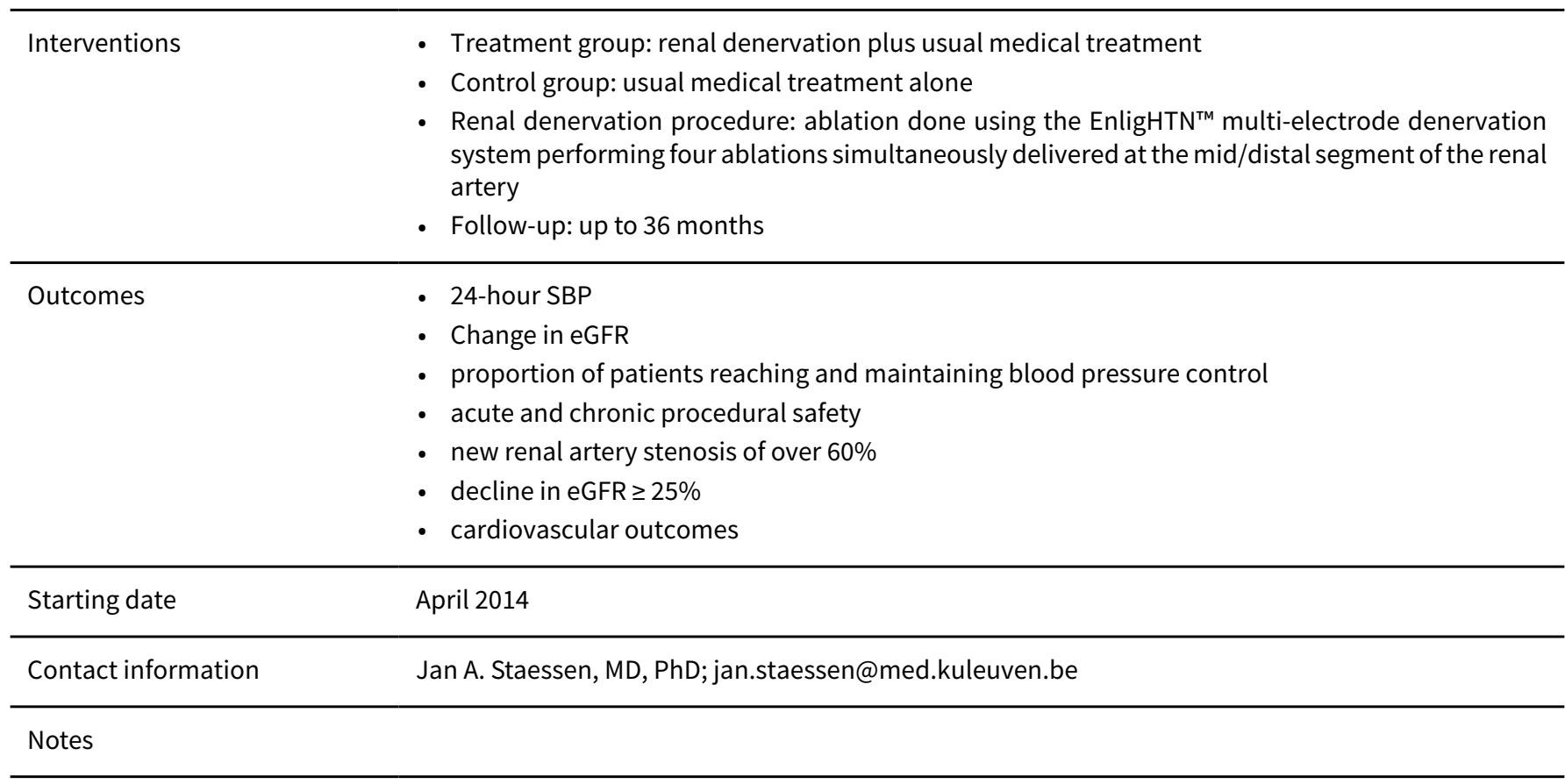

\section{KPS}

Trial name or title Renal protection using sympathetic denervation in patients with chronic kidney disease (KPS)

\begin{tabular}{|c|c|}
\hline Methods & $\begin{array}{l}\text { - Study type: parallel, RCT } \\
\text { - Country: Czech Republic } \\
\text { - Setting: University/Hospital }\end{array}$ \\
\hline Participants & $\begin{array}{l}\text { - Estimated number of patients: } 40 \\
\text { - Age: range } 18 \text { to } 80 \text { years } \\
\text { - Office SBP (mmHg): } \geq 140 \mathrm{mmHg} \text { (despite stable medication regimen including } 3 \text { or more antihy- } \\
\text { pertensive medications of different classes, including a diuretic) } \\
\text { - eGFR }\left(\mathrm{mL} / \mathrm{min} / 1.73 \mathrm{~m}^{2}\right): \leq 45 \\
\text { Exclusion criteria: pregnancy, type } 1 \text { diabetes mellitus, significant valvular disease, renovascular } \\
\text { abnormalities, secondary hypertension, white coat hypertension }\end{array}$ \\
\hline Interventions & $\begin{array}{l}\text { - Treatment group: renal denervation and optimal medical therapy } \\
\text { - Control group: optimal medical therapy alone } \\
\text { - Follow-up: up to } 60 \text { months }\end{array}$ \\
\hline Outcomes & $\begin{array}{l}\text { - Changes of eGFR } \\
\text { - Changes in proteinuria (microalbuminuria) } \\
\text { - Changes in Cystatin C values } \\
\text { - Time to the development of end-stage renal disease (ESRD)/Hemodialysis } \\
\text { - Combined renal end point } \\
\text { - All-cause mortality } \\
\text { - Cardiovascular mortality } \\
\text { - Changes of systolic and diastolic blood pressure at } 6 \text { months }\end{array}$ \\
\hline
\end{tabular}


KPS (Continued)

- Changes in concentration of blood urea nitrogen (BUN), creatinine in 6 months

- Changes in cardiac structure and function

- Changes in renal resistive index

\begin{tabular}{ll}
\hline Starting date & November 2013 \\
\hline Contact information & Jean Claude Lubanda, Ass.Prof. MD; Jean-Claude.Lubanda@vfn.cz \\
\hline Notes & \\
\hline
\end{tabular}

\section{NCT01848275}

\begin{tabular}{|c|c|}
\hline Trial name or title & Full length versus proximal renal arteries ablation \\
\hline Methods & $\begin{array}{l}\text { - Study type: parallel, RCT } \\
\text { - Country: China } \\
\text { - Setting: University }\end{array}$ \\
\hline Participants & $\begin{array}{l}\text { - Estimated number of patients: } 40 \\
\text { - Age: }>18 \\
\text { - Office } \mathrm{SBP}(\mathrm{mmHg}): \geq 160 \\
\text { - eGFR }\left(\mathrm{mL} / \mathrm{min} / 1.73 \mathrm{~m}^{2}\right): \geq 45 \\
\text { Exclusion criteria: pregnancy, type } 1 \text { diabetes mellitus, significant valvular disease, ICD, renovascu- } \\
\text { lar abnormalities, secondary hypertension, white coat hypertension }\end{array}$ \\
\hline Interventions & $\begin{array}{l}\text { - Treatment group: full length renal denervation by the Thermocool }{ }^{\circledR} \mathrm{R} \text { catheter } \\
\text { - Control group: proximity renal denervation by the Thermocool }{ }^{\circledR} \mathrm{R} \text { catheter } \\
\text { - Follow-up: up to } 36 \text { months }\end{array}$ \\
\hline Outcomes & $\begin{array}{l}\text { - Office BP } \\
\text { - ABPM } \\
\text { - Ablation-related complications }\end{array}$ \\
\hline Starting date & March 2011 \\
\hline Contact information & Yuehui Yin, MD; yinyh63@163.com \\
\hline Notes & \\
\hline
\end{tabular}

\section{NCT01918111}

Trial name or title

Effects of renal denervation for resistant hypertension on exercise diastolic function and regression of atherosclerosis and the evaluation of new methods predicting a successful renal sympathetic denervation (RENEWAL-EXERCISE, -REGRESS, and -PREDICT Trial From RENEWAL RDN Registry)

\begin{tabular}{ll}
\hline Methods & - Study type: cross-over, RCT \\
& - Country: Republic of Korea \\
& - Setting: University \\
\hline Participants & Estimated number of patients: 52 \\
& Age: range 20 to 85 years
\end{tabular}


NCT01918111 (Continued)

- $\mathrm{BP} \geq 140 / 90 \mathrm{mmHg}$ or $\geq 130 / 80 \mathrm{mmHg}$ for patients with diabetes (despite stable medication regimen including 3 or more antihypertensive medications of different classes, including a diuretic)

- Exclusion criteria: Hemodynamically or anatomically significant renal artery abnormalities, main renal arteries $<4 \mathrm{~mm}$ in diameter or $<20 \mathrm{~mm}$ in length or prior renal artery intervention, eGFR $<30$ $\mathrm{mL} / \mathrm{min} / 1.73 \mathrm{~m}^{2}$, using the MDRD formula. Valvular heart disease, history of congestive heart failure with left ventricular ejection fraction $<35 \%$, ST-segment elevation MI within 48 hours, scheduled or planned surgery or cardiovascular intervention in the 6 months after procedure. Chronic diseases with life expectancy $<1$ year, hormone replace treatment and/or oral contraceptives, pregnant, nursing or planning to be pregnant, chronic liver cirrhosis

\begin{tabular}{ll}
\hline Interventions & Treatment group: renal denervation \\
- Control group: adenosine infusion treatment \\
- Renal denervation procedure: catheter-based renal denervation performed via common femoral \\
artery with standard endovascular technique and Simplicity catheter \\
- Follow-up: up to 24 months
\end{tabular}

\begin{tabular}{ll}
\hline Outcomes & $\cdot$ Change in BP at 6 and 12 months post procedure \\
\hline Starting date & September 2013 \\
\hline Contact information & Yangsoo Jang, MD 82-2-2228-8460, jangys1212@yuhs.ac \\
\hline Notes & \\
\hline
\end{tabular}

\section{NCT01968785}

\begin{tabular}{|c|c|}
\hline Trial name or title & Renal denervation in patients with uncontrolled blood pressure \\
\hline Methods & $\begin{array}{l}\text { - Study type: parallel, RCT } \\
\text { - Country: US } \\
\text { - Setting: University }\end{array}$ \\
\hline Participants & $\begin{array}{l}\text { - Estimated number of patients: } 20 \\
\text { - Age: range } 18 \text { to } 85 \text { years } \\
\text { - Office SBP (mmHg): } \geq 160 \text { ( } \geq 150 \mathrm{mmHg} \text { for type } 2 \text { diabetics) (despite stable medication regimen } \\
\text { including } 3 \text { or more antihypertensive medications of different classes, including a diuretic) } \\
\left.\text { - eGFR (mL/min } / 1.73 \mathrm{~m}^{2}\right): \geq 45 \\
\text { Exclusion criteria: pregnancy, type } 1 \text { diabetes mellitus, chronic oxygen support or mechanical ven- } \\
\text { tilation, primary pulmonary hypertension, previous renal denervation. Secondary hypertension, } \\
\text { significant renovascular abnormalities, myocardial infarction, unstable angina pectoris, or cere- } \\
\text { brovascular accident }<180 \text { days prior to enrolment. Blood clotting abnormalities, life expectancy < } \\
12 \text { months, renal arteries }<4 \text { mm in diameter or }<20 \text { mm in length or multiple renal arteries where } \\
\text { the main renal arteries supply < } 75 \% \text { of the kidney, abdominal aortic aneurysm (AAA). Pheochro- } \\
\text { mocytoma, Cushing's disease, coarctation of the aorta, hyperthyroidism, hyperparathyroidism }\end{array}$ \\
\hline Interventions & $\begin{array}{l}\text { - Treatment group: beta radiation dosage of } 50 \mathrm{~Gy} \text { during renal denervation procedure } \\
\text { - Control group: beta radiation dosage of } 25 \mathrm{~Gy} \text { during renal denervation procedure } \\
\text { - Follow-up: up to } 24 \text { months }\end{array}$ \\
\hline Outcomes & $\begin{array}{l}\text { - Safety (need for intervention to treat renal artery injury induced by the procedure within } 6 \\
\text { months) } \\
\text { - Decrease in SBP and } \mathrm{DBP} \geq 10 \mathrm{mmHg} \text { at six months following the procedure } \\
\text { - Effects on Blood Pressure }\end{array}$ \\
\hline
\end{tabular}


NCT01968785 (Continued)

- Acute procedural safety; renal artery dissection or perforation requiring intervention and serious groin complications specifically

- eGFR drop $>25 \%$ or new renal artery stenosis $>60 \%$ confirmed by angiogram at six months following renal artery brachytherapy procedure

- Medication changes

- Serious Adverse Events

\begin{tabular}{ll}
\hline Starting date & August 2013 \\
\hline Contact information & Ron Waksman, MD \\
\hline
\end{tabular}

Notes

NCT02021019

\begin{tabular}{ll}
\hline Trial name or title & Renal denervation to improve outcomes in patients with end-stage renal disease \\
\hline Methods & - Study type: parallel, RCT \\
& - Country: Australia \\
\hline Participants & - Estimated number of patients: 100 \\
& - Age: range 18 to 85 years \\
- Enfice SBP (mmH): $\geq 140 / 90$ \\
Exclusion criteria: myocardial infarction, unstable angina, cerebrovascular accident within 3 \\
months of the screening visit \\
- Treatment group: renal denervation \\
- Control group: usual care \\
- Renal denervation procedure: ablation done using catheter-based (Symplicity) radiofrequency \\
- Follow-up: up to 24 months
\end{tabular}

Outcomes

- Office SBP change 6 months after the procedure

\begin{tabular}{ll}
\hline Starting date & January 2014 \\
\hline Contact information & Markus P Schlaich, MD Baker IDI Heart and Diabetes Institute
\end{tabular}

Notes

\section{NCT02346045}

\begin{tabular}{ll}
\hline Trial name or title & Effect of renal denervation in end staged renal disease with resistant hypertension \\
\hline Methods & - Study type: parallel, RCT \\
& - Country: South Korea \\
\hline Participants & Setting: Hospital \\
\hline
\end{tabular}


NCT02346045 (Continued)

- Age: range 18 to 90 years

- Office BP ( $\mathrm{mmHg}$ ): $\geq 160$ (despite stable medication regimen including 3 or more antihypertensive medications of different classes, including a diuretic)

- Haemodialysis patients

Exclusion criteria: pregnancy, type 1 diabetes mellitus, secondary hypertension. ICD or pacemaker, myocardial infarction, unstable angina pectoris, syncope, cerebrovascular accident in the previous 6 months. Intravascular thrombosis or unstable atherosclerotic plaques, significant valvular heart disease, renal artery stenosis $(\geq 50 \%$ ) or renal artery aneurysm in either renal artery, history of prior renal artery intervention including balloon angioplasty or stenting, multiple renal arteries where the main renal artery is estimated to supply $<75 \%$ of the kidney. Main renal arteries with $<4$ $\mathrm{mm}$ diameter or with $<20 \mathrm{~mm}$ treatable length (by visual estimation). Renal artery abnormalities.

\begin{tabular}{ll}
\hline Interventions & Treatment group: renal sympathetic denervation + medical therapy \\
- Control group: sham procedure + medical therapy \\
- Renal denervation procedure: renal denervation from distal to proximal portion by a Symplicity \\
radiofrequency ablation catheter. Four to five ablations per each renal artery \\
- Follow-up: up to 24 months \\
\hline Outcomes & Change in office SBP \\
- Change in office DBP \\
- Change in ABPM \\
- Change in plasma norepinephrine \\
\hline
\end{tabular}

\begin{tabular}{ll}
\hline Starting date & September 2014 \\
\hline Contact information & Kiyuk Chang, MD, PhD; kiyuk@40catholic.ac.kr \\
\hline
\end{tabular}

Notes

\section{NCT02444442}

\begin{tabular}{|c|c|}
\hline Trial name or title & $\begin{array}{l}\text { The Australian SHAM controlled clinical trial of renal denervation in patients with resistant hyper- } \\
\text { tension }\end{array}$ \\
\hline Methods & $\begin{array}{l}\text { - Study type: parallel, RCT } \\
\text { - Country: Australia } \\
\text { - Setting: Hospital }\end{array}$ \\
\hline Participants & $\begin{array}{l}\text { - Estimated number of patients: } 105 \\
\text { - Age: range } 18 \text { to } 85 \text { years } \\
\text { - Systolic } \mathrm{BP} \geq 140 \mathrm{mmHg} \text { and ambulatory day time average } \geq 130 \mathrm{mmHg} \text { despite concurrent treat- } \\
\text { ment with } \geq 3 \text { anti-hypertensive drugs } \\
\text { Exclusion criteria: renal artery anatomy ineligible for treatment, eGFR }<15 \mathrm{~mL} / \mathrm{min} / 1.73 \mathrm{~m}^{2} \text { (using } \\
\text { MDRD calculation), myocardial infarction, unstable angina or cerebrovascular accident within } 3 \\
\text { months of screening visit, life expectancy }<12 \text { months, pregnancy }\end{array}$ \\
\hline Interventions & $\begin{array}{l}\text { - Treatment group: renal denervation } \\
\text { - Control group: sham procedure } \\
\text { - Renal denervation procedure: radiofrequency catheter-based therapy for renal denervation } \\
\text { - Follow-up: up to } 36 \text { months }\end{array}$ \\
\hline
\end{tabular}


NCT02444442 (Continued)

Outcomes

- Change in ambulatory SBP from baseline to 6 months

- Change in mean 24-hour SBP from baseline to 6 months

- Change in mean office SBP from baseline to 6 months

- Change in left ventricular function 6 months post procedure

- Change in serum biochemistry (Plasma Renin Activity, aldosterone levels, estimated Glomerular Filtration Rate (eGFR), inflammatory markers, fasting glucose, fasting insulin, C-peptide, Homeostasis Model Assessment (HOMA) index, Lipid profile) 6 months post procedure

- Change in urine biochemistry (Urinary albumin creatinine ratio (UACR), 24 hour urinary creatinine clearance, sodium) 6 months post procedure

- Change in quality of life

\begin{tabular}{ll}
\hline Starting date & June 2015 \\
\hline Contact information & Markus P Schlaich, Professor +61 3 85321502, Markus.Schlaich@bakeridi.edu.au \\
& Murray Esler, Professor +613 85321338, Murray.Esler@bakeridi.edu.au \\
\hline
\end{tabular}

Notes

\begin{tabular}{ll}
\hline Trial name or title & High frequency guided renal artery denervation for improving outcome of renal ablation procedure \\
\hline Methods & - Study type: parallel, RCT \\
& - Country: Russia \\
& Setting: Research Institute/Hospital \\
\hline Participants & Estimated number of patients: 170 \\
& - Age: range 18 to 80 years \\
& $\geq 160 / 100 \mathrm{~mm} \mathrm{Hg}($ severe resistant hypertension), despite treatment with 3 antihypertensive drugs \\
& (including a diuretic) \\
- eGFR $\left(\mathrm{mL} / \mathrm{min} / 1 \cdot 73 \mathrm{~m}^{2}\right): \geq 45$ (MDRD formula)
\end{tabular}

Exclusion criteria: secondary hypertension, severe renal artery stenosis or dual renal arteries, congestive heart failure, left ventricular ejection fraction $<35 \%$, previous renal artery stenting or angioplasty, type 1 diabetes mellitus

- Control group: renal denervation as standard procedure

- Renal denervation guided by HFS: high-frequency stimulation (HFS) used before the initial and after each radiofrequency (RF) delivery within the renal artery. Ablations of 8 to 12 watts applied from the first distal main renal artery bifurcation all the way back to the ostium and performed both longitudinally and rotationally within each renal artery.

- Renal denervation as standard procedure: ablations of 8 to 12 watts applied from the first distal main renal artery bifurcation all the way back to the ostium and performed both longitudinally and rotationally within each renal artery

- Follow-up: 12 months

\section{Outcomes}

- Number of responders to RD procedure up to 12 months

- Incidence of adverse events through 12 months after procedure 
NCT02608632 (Continued)

Contact information

NA

\section{Notes}

\section{NCT02667912}

\begin{tabular}{|c|c|}
\hline Trial name or title & Distal renal denervation \\
\hline Methods & $\begin{array}{l}\text { - Study type: parallel, RCT } \\
\text { - Country: Russia } \\
\text { - Setting: Research Institute }\end{array}$ \\
\hline Participants & $\begin{array}{l}\text { - Estimated number of patients: } 45 \\
\text { - Age: range } 18 \text { to } 80 \text { years } \\
\text { - Office BP (mmHg): } \geq 160 / 100 \mathrm{mmHg} \text {, with full doses of at least } 3 \text { antihypertensive drugs including } \\
\text { a diuretic } \\
\text { Exclusion criteria: secondary hypertension, } 24-\mathrm{h} \text { mean systolic } \mathrm{BP}<135 \mathrm{mmHg} \text {, eGFR }<30 \mathrm{~mL} / \\
\text { min/1.73 } \mathrm{m}^{2} \text {, disease of renal artery, any clinically important disorders/comorbidities significantly } \\
\text { increasing risk of endovascular intervention }\end{array}$ \\
\hline Interventions & $\begin{array}{l}\text { - Treatment group: distal renal denervation } \\
\text { - Control group: conventional renal denervation } \\
\text { - Distal renal denervation procedure: catheter-based renal denervation applied to inner surface of } \\
\text { segmental branches renal artery in a number of points equally distributed along the length and } \\
\text { circumference of the vessels } \\
\text { - Conventional renal denervation procedure: catheter-based renal denervation applied to inner } \\
\text { surface of the main trunk of renal artery in a number of points equally distributed along its length } \\
\text { and circumference } \\
\text { - Follow-up: up to } 12 \text { months }\end{array}$ \\
\hline
\end{tabular}

\section{Outcomes}

- Between-group difference in change of 24-hour mean systolic and diastolic BP assessed by ambulatory blood pressure monitoring (ABPM) at 6 and 12 months of follow-up

- Between-group difference in change of office systolic and diastolic BP at 6 and 12 months of follow-up

- Between-group difference in change of daytime/nighttime systolic and diastolic BP at 6 and 12 months of follow-up

- Between-group difference in renal function (serum creatine and eGFR) at 6 and 12 months of follow-up

- Between-group difference in the incidence of adverse events

\begin{tabular}{ll}
\hline Starting date & January 2013 \\
\hline Contact information & Stanislav Pekarskiy, MD, PhD \\
\hline
\end{tabular}

Notes

\section{NTR3444}

Trial name or title

Comparison of renal sympathetic denervation with spironolactone in patients with still a high blood pressure despite the use of 3 different antihypertensive agents 
NTR3444 (Continued)

\begin{tabular}{ll} 
Methods & Study type: parallel, RCT \\
& - Country: The Netherlands \\
\hline Participants & - Esting: Hospital \\
- Age: range 18 to 75 years \\
- Treatment-resistent hypertension \\
Exclusion criteria: secondary hypertension, renal arteries inaccessible for endovascular denerva- \\
tion, suboptimal dosing of BP lowering medication, non compliant to treatment, white coat hyper- \\
tension, pregnancy, eGFR $<45$ mL/min/1.73 $\mathrm{m}^{2}$, use of vitamin $\mathrm{K}$ antagonist that can not be discon- \\
tinued for a short period, spironolactone intolerance, myocardial infarction or cerebrovascular ac- \\
cident 3 months prior to randomisation, life expectancy $<2$ years
\end{tabular}

\begin{tabular}{ll}
\hline Interventions & Treatment group: renal denervation \\
& - Control group: antihypertensive treatment + spironolactone \\
& - Renal denervation procedure: catheter-based renal denervation \\
\hline Outcomes & - Between groups difference in 24-hour ambulatory BP after 6 months of follow-up \\
& Between groups difference in quality of life score \\
\hline Starting date & June 2012 \\
\hline Contact information & A van den Meiracker, MD, PhD +31-10-4639222, a.vandenmeiracker@erasmusmc.nl \\
\hline Notes & \\
\hline
\end{tabular}

\section{PaCE}

Trial name or title A study of renal denervation in patients with treatment resistant hypertension (PaCE)

\begin{tabular}{ll}
\hline Methods & Study type: parallel, RCT \\
& - Country: Canada \\
& - Setting: Hospital \\
\hline
\end{tabular}
Participants $\quad$ Estimated number of patients: 100
- Age: range 18 to 85 years
- $\operatorname{eGFR}\left(\mathrm{mL} / \mathrm{min} / 1.73 \mathrm{~m}^{2}\right): \geq 45$
- Office SBP $\geq 160 \mathrm{mmHg}$ (despite stable medication regimen including 3 or more antihypertensive medications of different classes, including a diuretic)
- Baseline average systolic ABPM $\geq 135 \mathrm{mmHg}$

Exclusion criteria: pregnancy, type 1 diabetes mellitus, chronic oxygen support or mechanical ventilation, primary pulmonary hypertension, previous renal denervation, secondary hypertension, significant renovascular abnormalities. Myocardial infarction, unstable angina pectoris or cerebrovascular accident $<180$ days prior to enrolment. Blood clotting abnormalities, life expectancy $<$ 12 months, renal arteries $<4 \mathrm{~mm}$ in diameter or $<20 \mathrm{~mm}$ in length or multiple renal arteries where the main renal arteries supply $<75 \%$ of the kidney. Pheochromocytoma, Cushing's disease, coarctation of the aorta 
PaCE (Continued)

- Renal denervation procedure: catheter-based renal denervation by applying low power radiofrequency to the renal artery using the Ardian Medtronic Simplicity catheter

- Follow-up: up to 24 months

\begin{tabular}{|c|c|}
\hline Outcomes & $\begin{array}{l}\text { - Average systolic ABPM } \\
\text { - Proportion of patients achieving target SBP } \\
\text { - Average daytime and night-time systolic ambulatory BP } \\
\text { - Variability of 24-hour ambulatory systolic BP } \\
\text { - Average office BP using an approved, automated office BP device } \\
\text { - Hypertensive medication complexity index (MRCI) } \\
\text { - Number of hypertensive medications } \\
\text { - Periprocedural mean cost per patient in Canadian dollars } \\
\text { - Generic quality of life (EQ-5D) } \\
\text { - Body mass index (BMI) } \\
\text { - 24-hour urine sodium } \\
\text { - Acute periprocedural renal injury } \\
\text { - Creatinine clearance measured on 24-hour urine } \\
\text { - Vascular complications } \\
\text { - Evidence of renal artery stenosis compared to pre-procedure (determined by renal imaging, CT } \\
\text { or MRA) for early intervention group } \\
\text { - Composite cardiovascular end points } \\
\text { - Microalbumin to creatinine ratio (MACR) from random urine sample }\end{array}$ \\
\hline Starting date & October 2013 \\
\hline Contact information & Harindra C. Wijeysundera, MD \\
\hline
\end{tabular}

\section{RAPID II}

\begin{tabular}{|c|c|}
\hline Trial name or title & Rapid renal sympathetic denervation for resistant hypertension II (RAPID II) \\
\hline Methods & $\begin{array}{l}\text { - Study type: parallel, RCT } \\
\text { - Country: Italy } \\
\text { - Setting: Hospital/University }\end{array}$ \\
\hline Participants & $\begin{array}{l}\text { - Estimated number of patients: not provided } \\
\text { - Age: range } 18 \text { to } 75 \text { years } \\
\text { - SBP (mmHg): } \geq 160 \text { (despite stable medication regimen including } 3 \text { or more antihypertensive } \\
\text { medications of different classes, including a diuretic) } \\
\text { Exclusion criteria: pregnancy,type } 1 \text { diabetes mellitus, renal anatomy unsuitable for treatment, sig- } \\
\text { nificant valvular heart disease, scheduled or planned surgery within } 6 \text { months of study entry }\end{array}$ \\
\hline Interventions & $\begin{array}{l}\text { - Treatment group: bilateral renal ablation plus antihypertensive medications } \\
\text { - Control group: optimal medical therapy } \\
\text { - Renal denervation procedure: catheter-based renal denervation by applying low power radiofre- } \\
\text { quency to the renal artery using the OneShot system } \\
\text { - Follow-up: up to } 60 \text { months }\end{array}$ \\
\hline Outcomes & $\begin{array}{l}\text { - Major adverse event (MAE) rate through } 30 \text { days post randomisation } \\
\text { - Change in office SBP from baseline to } 6 \text { months }\end{array}$ \\
\hline
\end{tabular}


RAPID II (Continued)

- Acute procedural safety

- Chronic procedural safety

- Reduction in SBP $>10 \mathrm{mmHg}$ at 6 months

- Changes in office SBP and DBP from baseline to follow-up visits

\begin{tabular}{ll}
\hline Starting date & September 2013 \\
\hline Contact information & Dierk Scheinert, MD \\
& Guiseppe Mancia, MD Universita Milano-Bicocca, Ospedale San Gerardo di Monza
\end{tabular}

Notes

RDNP-2012-01

\begin{tabular}{|c|c|}
\hline Trial name or title & Renal denervation for resistant hypertension (RDNP-2012-01) \\
\hline Methods & $\begin{array}{l}\text { - Study type: parallel, RCT } \\
\text { - Country: Australia } \\
\text { - Setting: Hospital }\end{array}$ \\
\hline Participants & $\begin{array}{l}\text { - Estimated number of patients: } 100 \\
\text { - Age: range } 18 \text { to } 85 \text { years } \\
\text { - } \mathrm{SBP} \geq 140 \mathrm{mmHg} \text { or } \geq 130 \mathrm{mmHg} \text { for patients with diabetes (despite stable medication regimen } \\
\text { including } 3 \text { or more antihypertensive medications of different classes, including a diuretic) } \\
\text { - eGFR }\left(\mathrm{mL} / \mathrm{min} / 1.73 \mathrm{~m}^{2}\right): \geq 15 \\
\text { Exclusion criteria: pregnancy, unsuitable anatomy of renal arteries (diameter }<4 \mathrm{~mm} \text { and length < } \\
20 \mathrm{~mm} \text { ) }\end{array}$ \\
\hline Interventions & $\begin{array}{l}\text { - Treatment group: renal denervation } \\
\text { - Control group: usual care } \\
\text { - Renal denervation procedure: catheter-based renal denervation by applying low power radiofre- } \\
\text { quency to the renal artery using the Ardian Medtronic Symplicity catheter } \\
\text { - Follow-up: up to } 24 \text { months }\end{array}$ \\
\hline Outcomes & $\begin{array}{l}\text { - Percentage of patients achieving BP target }(\mathrm{BP}<140 / 90 \mathrm{mmHg} \text {, or }<130 / 80 \mathrm{mmHg} \text { in diabetic } \\
\text { patients) at } 6 \text { months post procedure } \\
\text { - Time to achieve BP target } \\
\text { - Change in markers of sympathetic nerve activity } \\
\text { - Change in left ventricular structure and function } \\
\text { - Change in quality of life } \\
\text { - Serum and urine biochemistry } \\
\text { - Change in markers of arterial stiffness }\end{array}$ \\
\hline
\end{tabular}

\begin{tabular}{ll}
\hline Starting date & February 2012 \\
\hline Contact information & Markus Schlaich, MD Baker IDI Heart \& Diabetes Institute \\
\hline
\end{tabular}

\section{Notes}


Trial name or title

Effect of renal denervation on no-mediated sodium excretion and plasma levels of vasoactive hormones (RENO)

\begin{tabular}{|c|c|}
\hline Methods & $\begin{array}{l}\text { - Study type: parallel, RCT } \\
\text { - Country: Denmark } \\
\text { - Setting: Hospital }\end{array}$ \\
\hline Participants & $\begin{array}{l}\text { - Estimated number of patients: } 30 \\
\text { - Age: range } 30 \text { to } 70 \text { years } \\
\text { - Office } B P(\mathrm{mmHg}): \geq 145 / 75 \\
\text { - eGFR }\left(\mathrm{mL} / \mathrm{min} / 1.73 \mathrm{~m}^{2}\right): \geq 45 \\
\text { Exclusion criteria: non-compliance, pregnancy, radiocontrast allergy, malignancy, congestive heart } \\
\text { failure, unstable angina pectoris, previous myocardial infarction or PCI (<6 mdr), secondary hyper- } \\
\text { tension, renal artery stenosis or multiple renal arteries on CT, claudication }\end{array}$ \\
\hline Interventions & $\begin{array}{l}\text { - Treatment group: renal denervation plus L-NMMA treatment } \\
\text { - Control group: sham procedure plus L-NMMA treatment } \\
\text { - Renal denervation procedure: catheter-based renal denervation by applying low power radiofre- } \\
\text { quency to the renal artery using the Ardian Medtronic Simplicity catheter } \\
\text { - Follow-up: up to } 24 \text { months }\end{array}$ \\
\hline Outcomes & $\begin{array}{l}\text { - Fractional excretion of sodium after acute L-NMMA treatment } \\
\text { - Glomerular filtration rate (GFR) before and after L-NMMA treatment }\end{array}$ \\
\hline Starting date & March 2012 \\
\hline Contact information & Esper N Bech, MD, Ph.D; jnbech@dadlnet.dk \\
\hline Notes & \\
\hline
\end{tabular}

\section{RENSYMPIS}

\begin{tabular}{|c|c|}
\hline Trial name or title & Renal sympathetic denervation and insulin sensitivity (RENSYMPIS Study) \\
\hline Methods & $\begin{array}{l}\text { - Study type: parallel, RCT } \\
\text { - Country: Finland } \\
\text { - Setting: University }\end{array}$ \\
\hline Participants & $\begin{array}{l}\text { - Estimated number of patients: } 60 \\
\text { - Age: range } 30 \text { to } 69 \text { years } \\
\text { - Office systolic } \mathrm{BP}(\mathrm{mmHg}): \geq 160 \\
\text { - eGFR }\left(\mathrm{mL} / \mathrm{min} / 1.73 \mathrm{~m}^{2}\right): \geq 45 \\
\text { Exclusion criteria: secondary hypertension, pseudohypertension, pregnancy, significant stenotic } \\
\text { valvular disease, oral anticoagulation, CCS III-IV symptoms or CABG/PCl in the previous } 6 \text { months, } \\
\text { prior stroke, contrast agent allergy, inappropriate renal artery anatomy }(<4 \mathrm{~mm} \text { diameter, }<20 \mathrm{~mm} \\
\text { length) }\end{array}$ \\
\hline Interventions & $\begin{array}{l}\text { - Treatment group: renal artery denervation } \\
\text { - Control group: optimisation of medical therapy } \\
\text { - Renal denervation procedure: catheter-based renal denervation by applying low power radiofre- } \\
\text { quency to the renal artery using the Ardian Medtronic Simplicity catheter }\end{array}$ \\
\hline
\end{tabular}


RENSYMPIS (Continued)

- Follow-up: up to 36 months

\begin{tabular}{ll}
\hline Outcomes & Office BP \\
& - Ambulatory BP \\
& - Insulin resistance \\
& - Endothelial function
\end{tabular}

\begin{tabular}{ll}
\hline Starting date & January 2013 \\
\hline Contact information & Tuomas Paana, M.D; tuomas.paana@satshp.fi \\
\hline
\end{tabular}

Notes

ReSET-2

\begin{tabular}{ll}
\hline Trial name or title & Renal denervation in treatment resistant hypertension (ReSET-2) \\
\hline Methods & - Study type: parallel, RCT \\
& - Country: Denmark \\
& - Setting: University \\
\hline Participants & Estimated number of patients: 70 \\
& - Systolic daytime $(24$-hour ambulatory blood pressure measurement $)>135 \mathrm{mmHg}$ and $<145$ \\
& mmHg \\
& eGFR $\left(\mathrm{mL} / \mathrm{min} / 1.73 \mathrm{~m}^{2}\right):>30$
\end{tabular}

Exclusion criteria: pregnancy, non compliance, heart failure (NYHA 3-4), Left ventricular ejection fraction $<50 \%$, unstable coronary heart disease, coronary intervention within 6 months, myocardial infarction within 6 months, claudication, orthostatic syncope within 6 months, secondary hypertension, permanent atrial fibrillation, significant heart valve disease. Clinically significant abnormal electrolytes, haemoglobin, liver enzymes and TSH. Second and third degree heart block, macroscopic haematuria, proximal significant coronary stenosis, renal artery anatomy not suitable for renal ablation (stenosis, diameter $<4 \mathrm{~mm}$, length $<20 \mathrm{~mm}$, multiple renal arteries, severe calcifications). Moderate/severe obstructive sleep apnoea (AHI > 15) if on CPAP treatment

\begin{tabular}{ll}
\hline Interventions & Treatment group: renal denervation \\
& - Control group: sham procedure \\
& Renal denervation procedure: catheter-based renal denervation by applying low \\
- Follow-up: up to 36 months
\end{tabular}


ReSET-2 (Continued)

Ole Mathiassen, MD, PhD onm@farm.au.dk

Notes

\section{RSD4CKD}

Trial name or title

Renal sympathetic denervation in patients with chronic kidney disease and resistant hypertension (RSD4CKD)

\begin{tabular}{ll}
\hline Methods & - Study type: parallel, RCT \\
& - Country: Japan \\
\hline Participants & - Estimg: University \\
& - Age: range 18 to 75 years \\
& - eGFR $\left(\mathrm{mL} / \mathrm{min} / 1.73 \mathrm{~m}^{2}\right):>20$ and $<70$ \\
& - Serum creatinine $(\mathrm{mg} / \mathrm{dL}): 1.5-5.0$ \\
& - Rersistent proteinuria \\
& - Nondiabetic renal disease
\end{tabular}

Exclusion criteria: treatment with corticosteroids, nonsteroidal antiinflammatory or immunosuppressive drugs, connective-tissue disease, obstructive uropathy, congestive heart failure (NYHA class III or IV), significant renovascular abnormalities (history of prior renal artery intervention, including balloon angioplasty or stenting; double renal artery on one side, distortion, and extension), measured by abdominal ultrasound or renal angiograms. History of myocardial infarction, unstable angina, cerebrovascular accident or alimentary tract haemorrhage in the previous 3 months, sick sinus syndrome, history of allergy to contrast media, psychiatric disorders, drug or alcohol abuse and pregnancy

- Treatment group: renal denervation + standard therapy
- Control group: standard therapy
- Renal denervation procedure: six to nine ablations at $10 \mathrm{~W}$ for 1 min each in both renal arteries
- Follow-up: up to 36 months

- All-cause mortality
- Doubling of serum creatinine or end-stage renal disease
- Urinary protein excretion and renal function
- Blood pressure
- Blood glucose
- Arrdiac function and structure
- Pulse wave velocity
- Quality of life
- Rehospitalisation rate
- Dialysis proportion

\section{Starting date}

November 2012

Contact information

Shan Qi jun; qjshan@njmu.edu.cn

Notes 
RSDforAF

\section{Trial name or title}

Renal sympathetic denervation in patients with drug-resistant hypertension and symptomatic atrial fibrillation (RSDforAF)
Interventions
- Study type: parallel, RCT

- Country: China

- Setting: Hospital
- Estimated number of patients: 200

- Age: range 18 to 75 years

- Office SPB $\geq 160 \mathrm{mmHg}$ (despite stable medication regimen including 3 or more antihypertensive medications of different classes, including a diuretic)

- Baseline average systolic AMBP $\geq 135 \mathrm{mmHg}$

- eGFR $\left(\mathrm{mL} / \mathrm{min} / 1.73 \mathrm{~m}^{2}\right): \geq 45$

- Paroxysmal and persistent AF

Exclusion Criteria: pregnancy, type 1 diabetes mellitus, chronic oxygen support or mechanical ventilation, primary pulmonary hypertension, white-coat hypertension, previous renal denervation, secondary hypertension, significant renovascular abnormalities, myocardial infarction, unstable angina pectoris or cerebrovascular accident $<180$ days prior to enrolment. Blood clotting abnormalities, life expectancy $<12$ months, renal arteries $<4 \mathrm{~mm}$ in diameter or $<20 \mathrm{~mm}$ in length or multiple renal arteries where the main renal arteries supply $<75 \%$ of the kidney. Pheochromocytoma, Cushing's disease, coarctation of the aorta, severely enlarged left atria $\geq 55 \mathrm{~mm}$, sick sinus syndrome, reversible causes of $\mathrm{AF}$

- Treatment group: renal denervation + drugs + cardioversion

- Control group: drugs

- Renal denervation procedure: four to eight ablations at $10 \mathrm{~W}$ for 60 seconds each in both renal arteries. In patients with persistent AF, direct-current cardioversion performed immediately after renal sympathetic denervation

- Follow-up: up to 36 months
- Change in atrial fibrillation burden

- Rate controlling in persistent AF patients

- Office SBP

- Changes in cardiac structure and function

- Fasting blood glucose

- Glycated haemoglobin

- Blood lipids

- Apnea-hypopnea index

- Pulse wave velocity

- Quality of life

Starting date July 2012


SYMPATHY (Continued)

\begin{tabular}{|c|c|}
\hline Methods & $\begin{array}{l}\text { - Study type: parallel, RCT } \\
\text { - Country: The Netherlands } \\
\text { - Setting: Hospital }\end{array}$ \\
\hline Participants & $\begin{array}{l}\text { - Estimated number of patients: } 300 \\
\text { - Age: } \geq 18 \text { years } \\
\text { - Average systolic ABPM } \geq 135 \mathrm{mmHg} \text { (despite stable medication regimen including } 3 \text { or more anti- } \\
\text { hypertensive medications of different classes, including a diuretic) } \\
\text { Exclusion Criteria: Pregnancy, type } 1 \text { diabetes mellitus, eGFR }\left(\mathrm{mL} / \mathrm{min} / 1.73 \mathrm{~m}^{2}\right)<20 \text {, chronic oxy- } \\
\text { gen support or mechanical ventilation, primary pulmonary hypertension, white-coat hypertension, } \\
\text { previous renal denervation, secondary hypertension, significant renovascular abnormalities. My- } \\
\text { ocardial infarction, unstable angina pectoris or cerebrovascular accident }<180 \text { days prior to enrol- } \\
\text { ment. Blood clotting abnormalities, life expectancy }<12 \text { months, renal arteries }<4 \mathrm{~mm} \text { in diame- } \\
\text { ter or }<20 \mathrm{~mm} \text { in length or multiple renal arteries where the main renal arteries supply }<75 \% \text { of the } \\
\text { kidney. Pheochromocytoma, Cushing's disease, coarctation of the aorta }\end{array}$ \\
\hline Interventions & $\begin{array}{l}\text { - Treatment group: renal denervation plus usual medical treatment } \\
\text { - Control group: usual medical treatment alone } \\
\text { - Renal denervation procedure: ablation done using the EnligHTN }{ }^{\mathrm{TM}} \text { multi-electrode denervation } \\
\text { system performing four ablations simultaneously. One } 60-\mathrm{s} \text { ablation delivered at the mid/distal } \\
\text { segment of the renal artery } \\
\text { - Follow-up: up to } 12 \text { months }\end{array}$ \\
\hline Outcomes & $\begin{array}{l}\text { - Change in ABPM } \\
\text { - Change in the amount of antihypertensive medication } \\
\text { - Change in BP in eGFR strata } \\
\text { - Change in office BP } \\
\text { - Impact on quality of life } \\
\text { - Cost-effectiveness }\end{array}$ \\
\hline
\end{tabular}

\begin{tabular}{ll}
\hline Starting date & May 2013 \\
\hline Contact information & Peter J Blankestijn, MD, PhD; P.J.Blankestijn@40umcutrecht.nl \\
\hline
\end{tabular}

Notes

\section{SYMPLICITY HTN-4}

\begin{tabular}{ll}
\hline Trial name or title & Renal denervation in patients with uncontrolled hypertension (SYMPLICITY HTN-4) \\
\hline Methods & - Study type: parallel, RCT \\
& - Country: USA \\
\hline Participants & - Estimated University \\
- Age: range 18 to 80 years \\
- eGFR $\left(\mathrm{mL} / \mathrm{min} / 1.73 \mathrm{~m}^{2}\right):>30$ \\
- Office $\mathrm{SBP}>140 \mathrm{mmHg}$ and $<160 \mathrm{mmHg}$ (despite stable medication regimen including 3 or more \\
antihypertensive $\mathrm{medications}$ of different classes, including a diuretic) \\
- ABPM average $\mathrm{SBP}>135 \mathrm{mmHg}$
\end{tabular}


SYMPLICITY HTN-4 (Continued)

Exclusion Criteria: pregnancy, inappropriate renal artery anatomy, type 1 diabetes mellitus, one or more episodes of orthostatic hypotension, chronic oxygen other than nocturnal respiratory support for sleep apnoea, primary pulmonary hypertension, previous organ transplant

\begin{tabular}{ll}
\hline Interventions & Treatment group: renal denervation \\
& - Control group: sham procedure \\
- Renal denervation procedure: ablations done with the SYMPLICITY system \\
- Follow-up: up to 24 months
\end{tabular}

\section{Outcomes}

- Reaching BP goal

- Incidence of major adverse events through 1 month post-procedure

- Renal artery stenosis measured at 6 months

\begin{tabular}{ll}
\hline Starting date & October 2013 \\
\hline Contact information & David Kandzari, MD Piedmont Heart Institute \\
\hline
\end{tabular}

Notes

DATA AND ANALYSES

\section{Comparison 1. Renal denervation vs. sham/standard therapy}

\begin{tabular}{|c|c|c|c|c|}
\hline $\begin{array}{l}\text { Outcome or subgroup } \\
\text { title }\end{array}$ & No. of studies & $\begin{array}{l}\text { No. of partici- } \\
\text { pants }\end{array}$ & Statistical method & Effect size \\
\hline 1 Myocardial infarction & 4 & 742 & Risk Ratio (M-H, Random, 95\% Cl) & $1.31[0.45,3.84]$ \\
\hline 2 ischaemic stroke & 4 & 823 & Risk Ratio (M-H, Random, 95\% Cl) & $1.15[0.36,3.72]$ \\
\hline 3 unstable angina & 2 & 201 & Risk Ratio (M-H, Random, 95\% Cl) & $0.63[0.08,5.06]$ \\
\hline 4 systolic 24-hour ABPM & 5 & 797 & Mean Difference (IV, Random, 95\% CI) & $0.28[-3.74,4.29]$ \\
\hline 5 diastolic 24-hour ABPM & 4 & 756 & Mean Difference (IV, Random, 95\% CI) & $0.93[-4.50,6.36]$ \\
\hline 6 systolic office BP & 6 & 886 & Mean Difference (IV, Random, 95\% Cl) & $-4.08[-15.26,7.11]$ \\
\hline 7 diastolic office BP & 5 & 845 & Mean Difference (IV, Random, 95\% CI) & $-1.30[-7.30,4.69]$ \\
\hline 8 serum creatinine & 3 & 736 & Mean Difference (IV, Random, 95\% Cl) & $0.01[-0.12,0.14]$ \\
\hline $\begin{array}{l}9 \text { eGFR/creatinine clear- } \\
\text { ance }\end{array}$ & 4 & 837 & Mean Difference (IV, Random, 95\% CI) & $-2.09[-8.12,3.95]$ \\
\hline 10 bradycardia & 3 & 220 & Risk Ratio (M-H, Random, 95\% Cl) & $6.63[1.19,36.84]$ \\
\hline $\begin{array}{l}11 \text { femoral artery } \\
\text { pseudoaneurysm }\end{array}$ & 2 & 201 & Risk Ratio (M-H, Random, 95\% Cl) & $3.96[0.44,35.22]$ \\
\hline 12 flank pain & 2 & 199 & Risk Ratio (M-H, Random, 95\% Cl) & $4.30[0.48,38.28]$ \\
\hline
\end{tabular}




\begin{tabular}{lllll}
\hline $\begin{array}{l}\text { Outcome or subgroup } \\
\text { title }\end{array}$ & No. of studies & $\begin{array}{l}\text { No. of partici- } \\
\text { pants }\end{array}$ & Statistical method & Effect size \\
\hline 13 hypotensive episodes & 2 & 119 & Risk Ratio (M-H, Random, 95\% Cl) & $0.67[0.07,6.64]$ \\
\hline 14 hypertensive crisis & 3 & 722 & Risk Ratio (M-H, Random, 95\% Cl) & $0.71[0.35,1.45]$ \\
\hline 15 hyperkalemia & 2 & 200 & Risk Ratio (M-H, Random, 95\% Cl) & $0.48[0.01,21.33]$ \\
\hline
\end{tabular}

Analysis 1.1. Comparison 1 Renal denervation vs. sham/standard therapy, Outcome 1 Myocardial infarction.

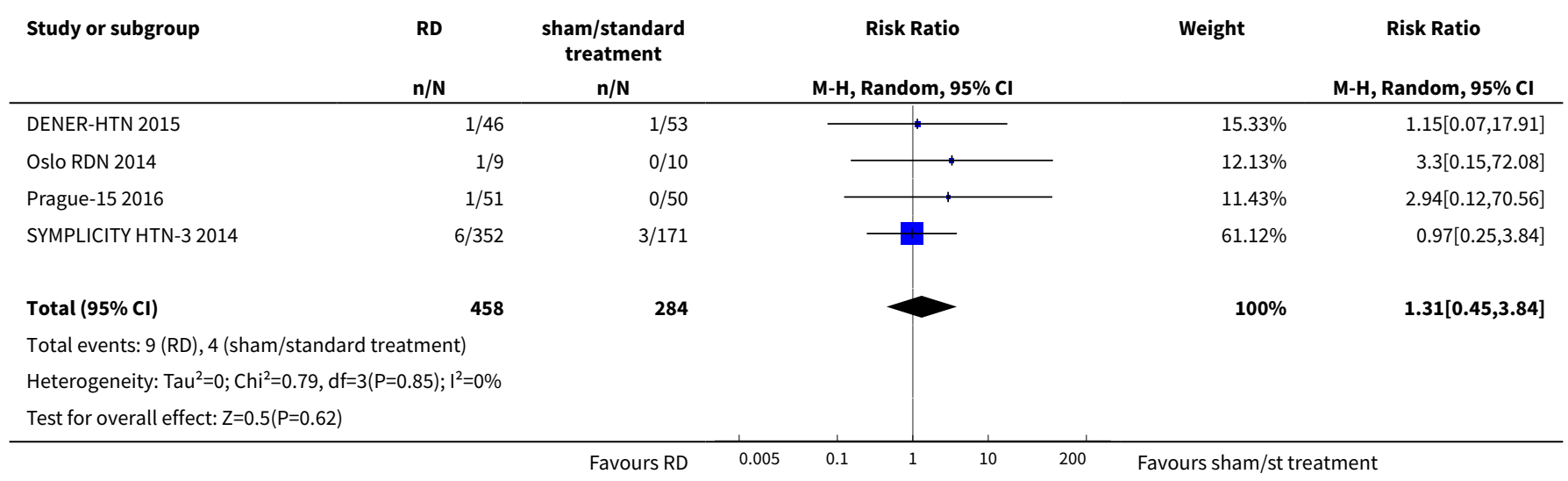

Analysis 1.2. Comparison 1 Renal denervation vs. sham/standard therapy, Outcome 2 ischaemic stroke.

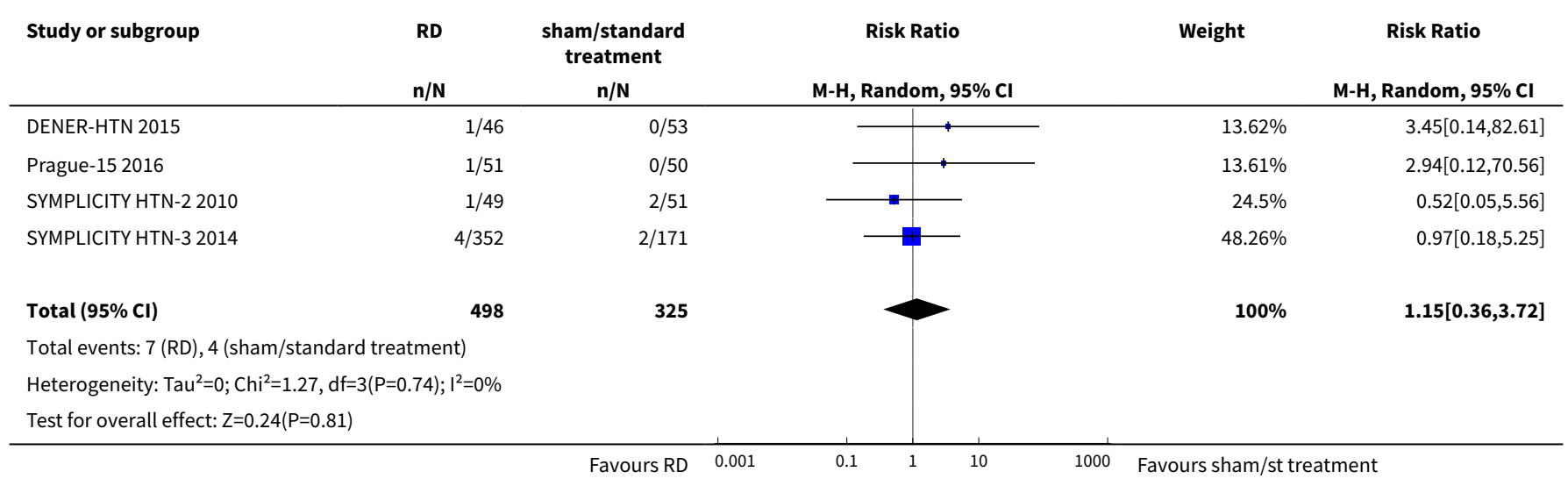

Analysis 1.3. Comparison 1 Renal denervation vs. sham/standard therapy, Outcome 3 unstable angina.

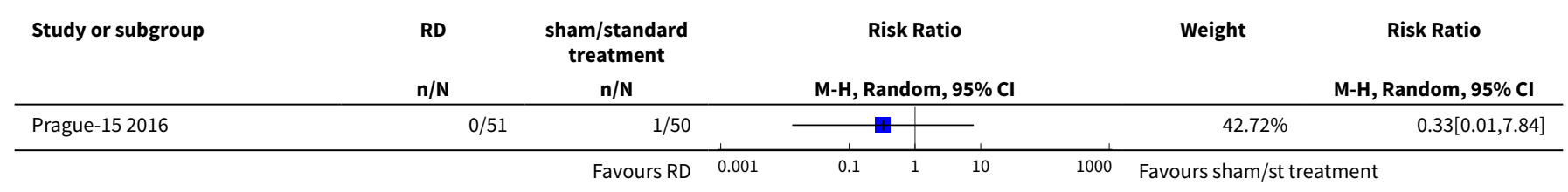




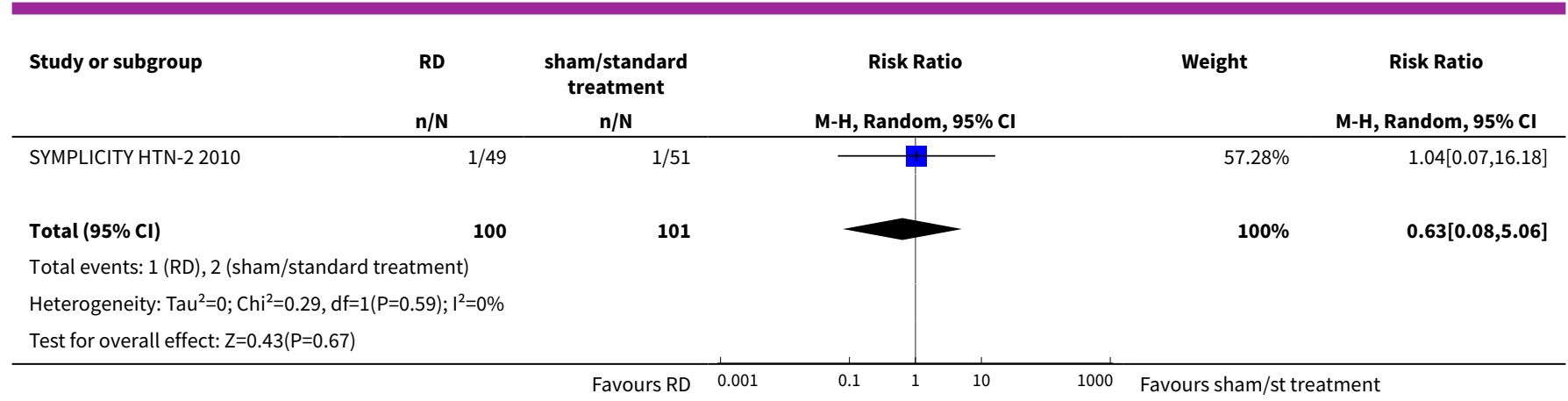

Analysis 1.4. Comparison 1 Renal denervation vs. sham/standard therapy, Outcome 4 systolic 24-hour ABPM.

\begin{tabular}{|c|c|c|c|c|c|c|c|}
\hline \multirow[t]{2}{*}{ Study or subgroup } & \multicolumn{2}{|r|}{ RD } & \multicolumn{2}{|c|}{$\begin{array}{c}\text { sham/stan- } \\
\text { dard treatment }\end{array}$} & \multirow{2}{*}{$\begin{array}{l}\text { Mean Difference } \\
\text { Random, } 95 \% \mathrm{CI}\end{array}$} & \multirow[t]{2}{*}{ Weight } & \multirow{2}{*}{$\begin{array}{l}\text { Mean Difference } \\
\text { Random, } 95 \% \mathrm{Cl}\end{array}$} \\
\hline & $\mathbf{N}$ & Mean(SD) & $\mathbf{N}$ & Mean(SD) & & & \\
\hline HTN-JAPAN 2015 & 22 & $157.1(19.3)$ & 19 & $161.9(18.6)$ & 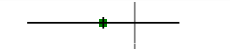 & $9.52 \%$ & $-4.8[-16.42,6.82]$ \\
\hline Oslo RDN 2014 & 9 & $139(10)$ & 10 & $130(12)$ & & $12.19 \%$ & $9[-0.9,18.9]$ \\
\hline DENER-HTN 2015 & 48 & $135.5(17.6)$ & 53 & $137.9(16.4)$ & $\longrightarrow$ & $20.53 \%$ & $-2.4[-9.05,4.25]$ \\
\hline Prague-15 2016 & 51 & $142(16)$ & 50 & $138(16)$ & 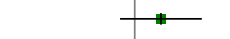 & $22.03 \%$ & $4[-2.24,10.24]$ \\
\hline SYMPLICITY HTN-3 2014 & 364 & $151.8(16)$ & 171 & $153.9(19.1)$ & 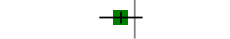 & $35.73 \%$ & $-2.1[-5.4,1.2]$ \\
\hline Total ${ }^{\star \star \star}$ & 494 & & 303 & & & $100 \%$ & $0.28[-3.74,4.29]$ \\
\hline \multicolumn{8}{|c|}{ Heterogeneity: $\operatorname{Tau}^{2}=8.9 ; \mathrm{Chi}^{2}=7.27, \mathrm{df}=4(\mathrm{P}=0.12) ; \mathrm{I}^{2}=45.01 \%$} \\
\hline \multicolumn{3}{|c|}{ Test for overall effect: $Z=0.14(P=0.89)$} & & & & & \\
\hline
\end{tabular}

Analysis 1.5. Comparison 1 Renal denervation vs. sham/standard therapy, Outcome 5 diastolic 24-hour ABPM.

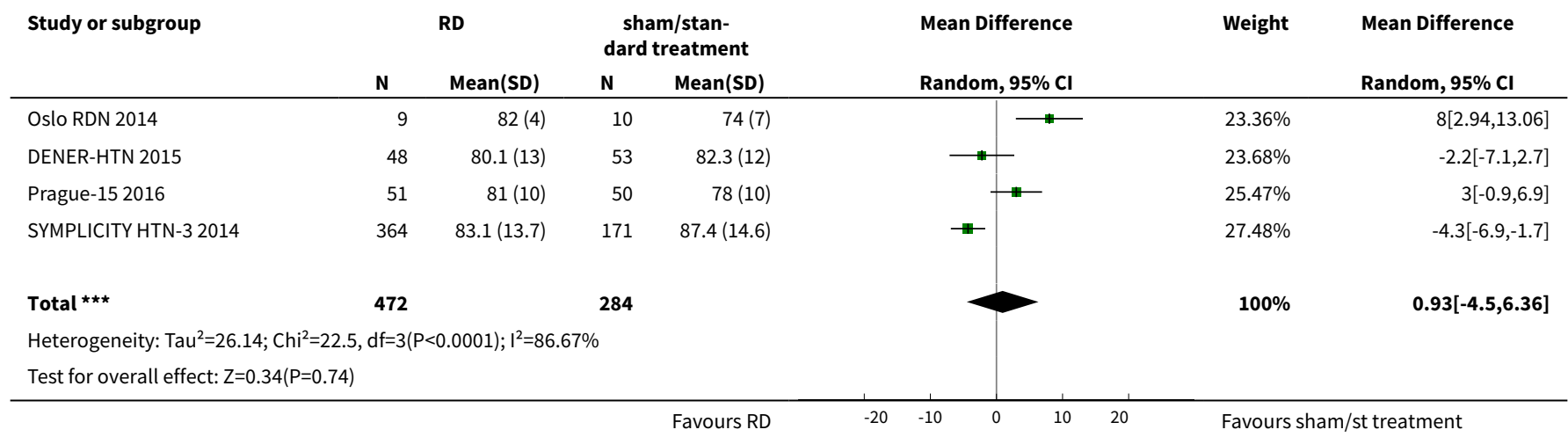


Analysis 1.6. Comparison 1 Renal denervation vs. sham/standard therapy, Outcome 6 systolic office BP.

\begin{tabular}{|c|c|c|c|c|c|c|c|}
\hline \multirow[t]{2}{*}{ Study or subgroup } & \multicolumn{2}{|r|}{ RD } & \multicolumn{2}{|c|}{$\begin{array}{c}\text { sham/stan- } \\
\text { dard treatment }\end{array}$} & \multirow{2}{*}{$\begin{array}{l}\text { Mean Difference } \\
\text { Random, } 95 \% \mathrm{Cl}\end{array}$} & \multirow[t]{2}{*}{ Weight } & \multirow{2}{*}{$\begin{array}{l}\text { Mean Difference } \\
\text { Random, } 95 \% \mathrm{Cl}\end{array}$} \\
\hline & $\mathbf{N}$ & Mean(SD) & $\mathbf{N}$ & Mean(SD) & & & \\
\hline HTN-JAPAN 2015 & 22 & $165.7(26.1)$ & 19 & $170.8(19.5)$ & $\longrightarrow$ & $14.43 \%$ & $-5.1[-19.09,8.89]$ \\
\hline SYMPLICITY HTN-2 2010 & 49 & $146.7(23.3)$ & 51 & $179.1(26.5)$ & $\longrightarrow$ & $16.32 \%$ & $-32.4[-42.17,-22.63]$ \\
\hline DENER-HTN 2015 & 48 & $143.5(20.4)$ & 53 & $147.3(24.1)$ & $\rightarrow$ & $16.76 \%$ & $-3.8[-12.48,4.88]$ \\
\hline Oslo RDN 2014 & 9 & $148(7)$ & 10 & $132(10)$ & —- & $17.13 \%$ & $16[8.3,23.7]$ \\
\hline SYMPLICITY HTN-3 2014 & 353 & $165.6(23.7)$ & 171 & $168.4(28.6)$ & $\rightarrow$ & $17.99 \%$ & $-2.8[-7.75,2.15]$ \\
\hline 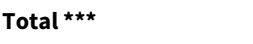 & 532 & & 354 & & & $100 \%$ & $-4.08[-15.26,7.11]$ \\
\hline \multicolumn{8}{|c|}{ Heterogeneity: $\operatorname{Tau}^{2}=174.65 ; \mathrm{Chi}^{2}=59.87, \mathrm{df}=5(\mathrm{P}<0.0001) ; \mathrm{I}^{2}=91.65 \%$} \\
\hline \multicolumn{8}{|c|}{ Test for overall effect: $\mathrm{Z}=0.71(\mathrm{P}=0.47)$} \\
\hline
\end{tabular}

Analysis 1.7. Comparison 1 Renal denervation vs. sham/standard therapy, Outcome 7 diastolic office BP.

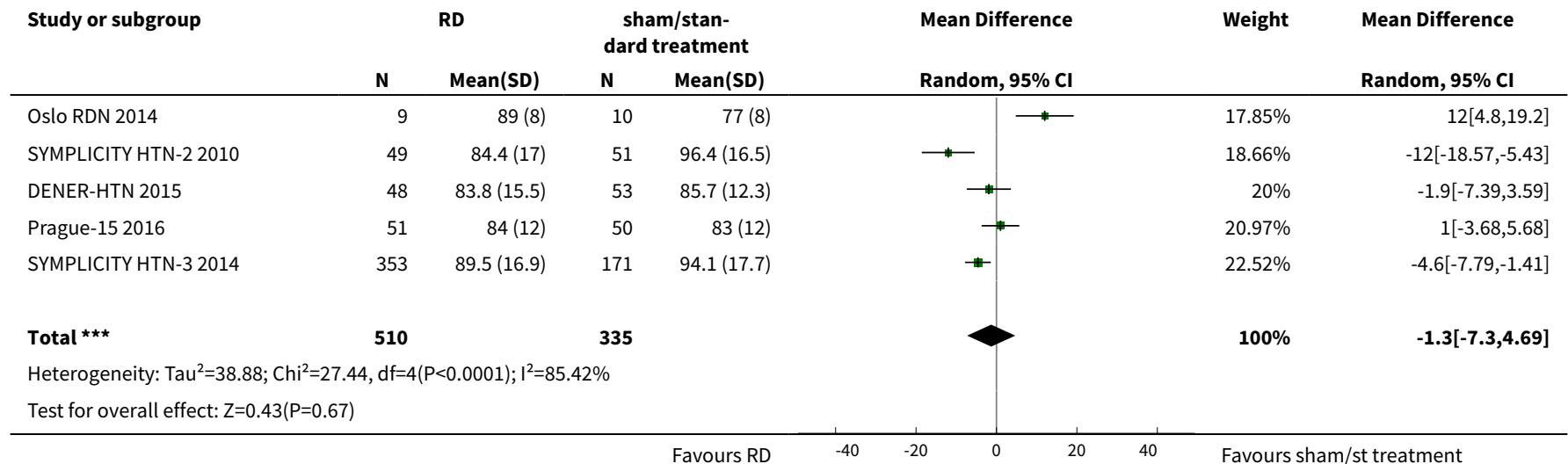

Analysis 1.8. Comparison 1 Renal denervation vs. sham/standard therapy, Outcome 8 serum creatinine.

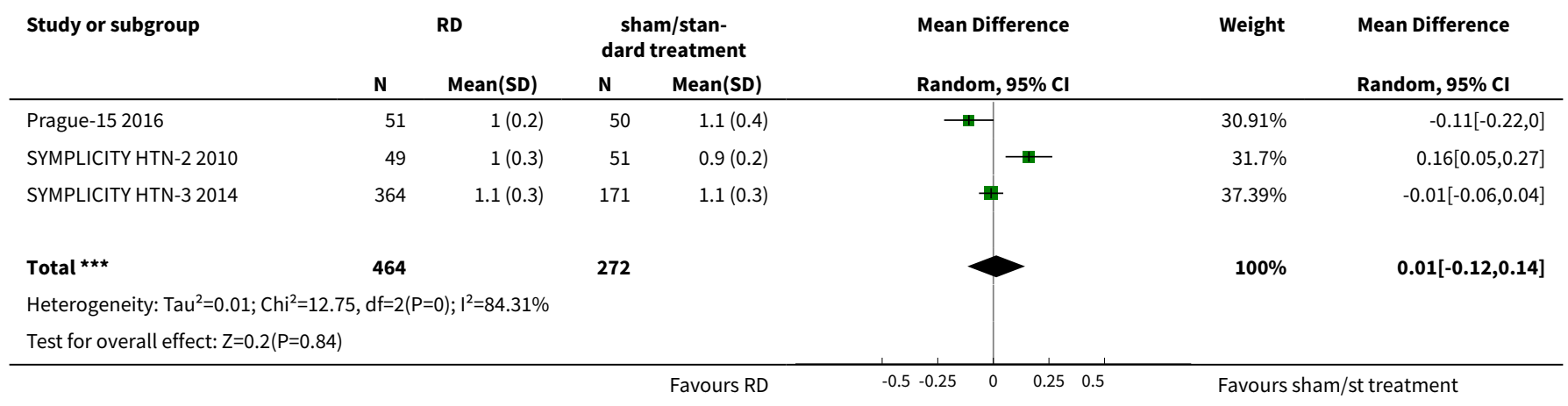


Analysis 1.9. Comparison 1 Renal denervation vs. sham/standard therapy, Outcome 9 eGFR/creatinine clearance.

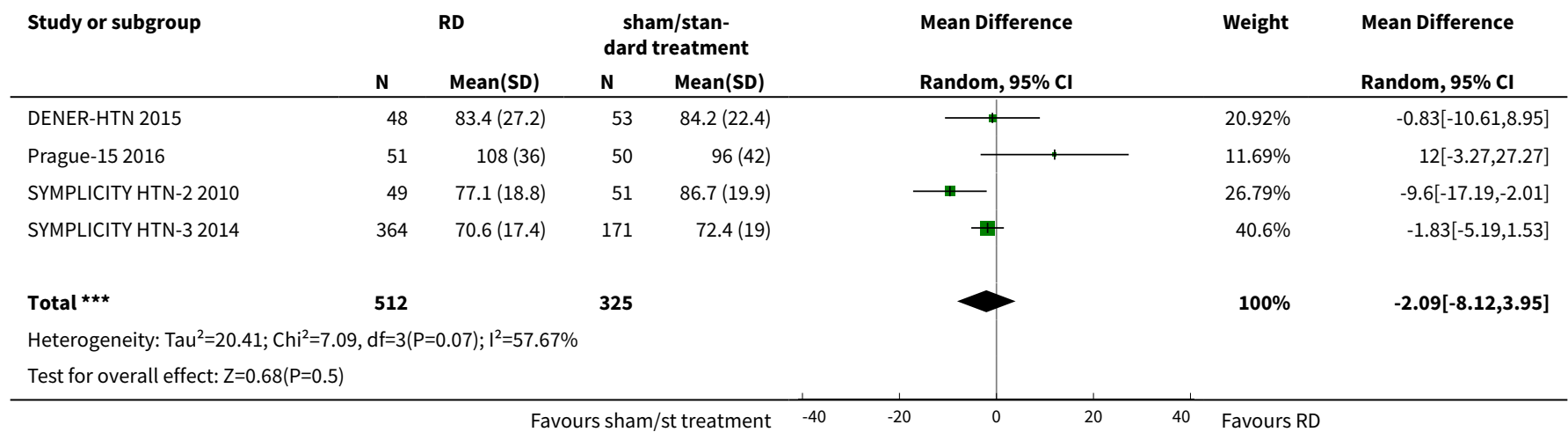

Analysis 1.10. Comparison 1 Renal denervation vs. sham/standard therapy, Outcome 10 bradycardia.

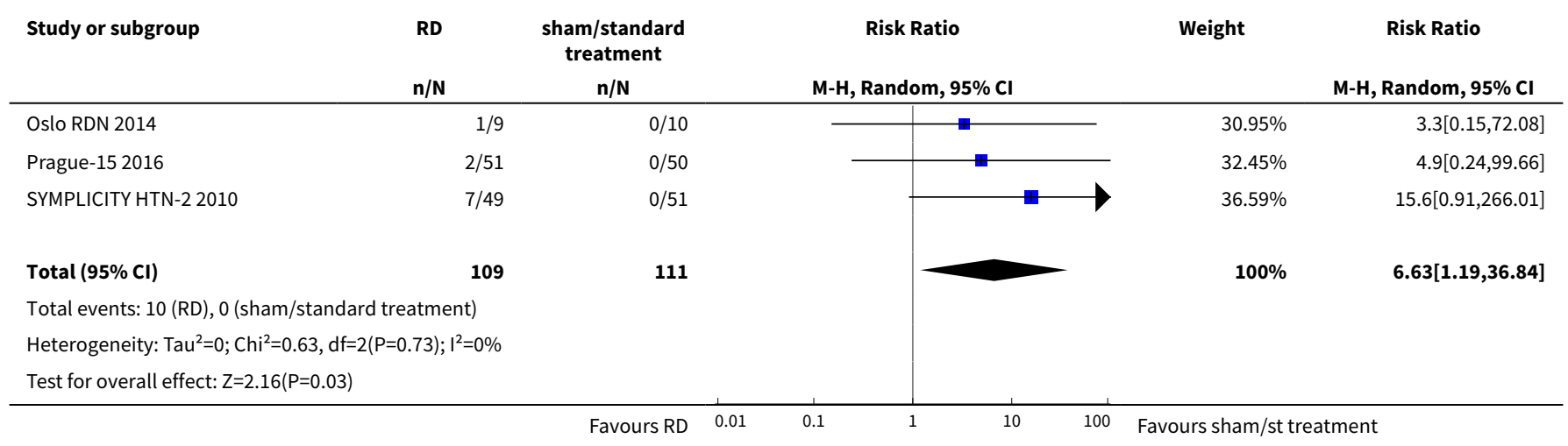

Analysis 1.11. Comparison 1 Renal denervation vs. sham/ standard therapy, Outcome 11 femoral artery pseudoaneurysm.

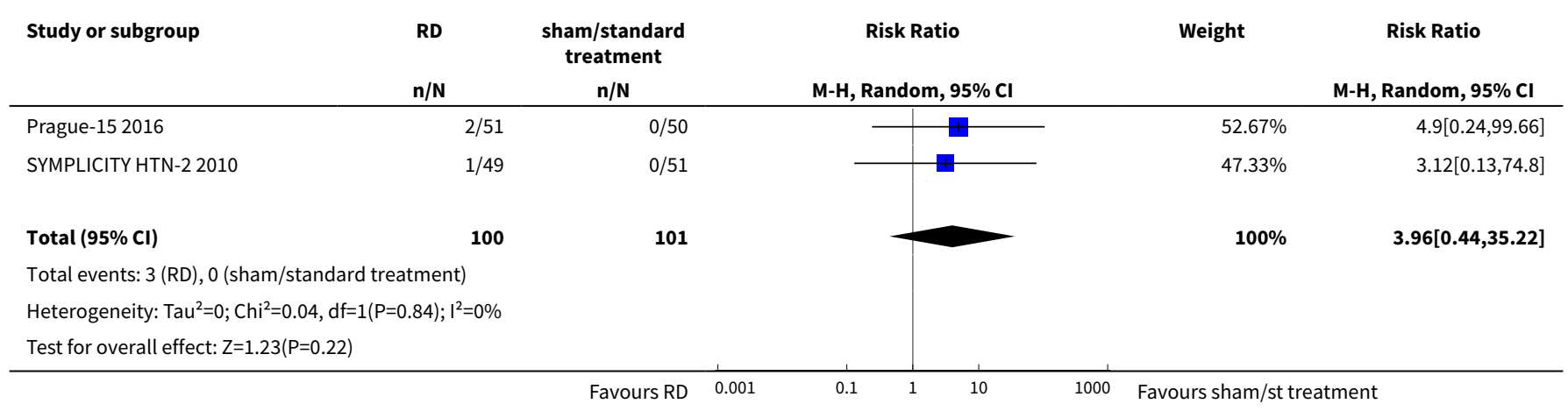


Analysis 1.12. Comparison 1 Renal denervation vs. sham/standard therapy, Outcome 12 flank pain.

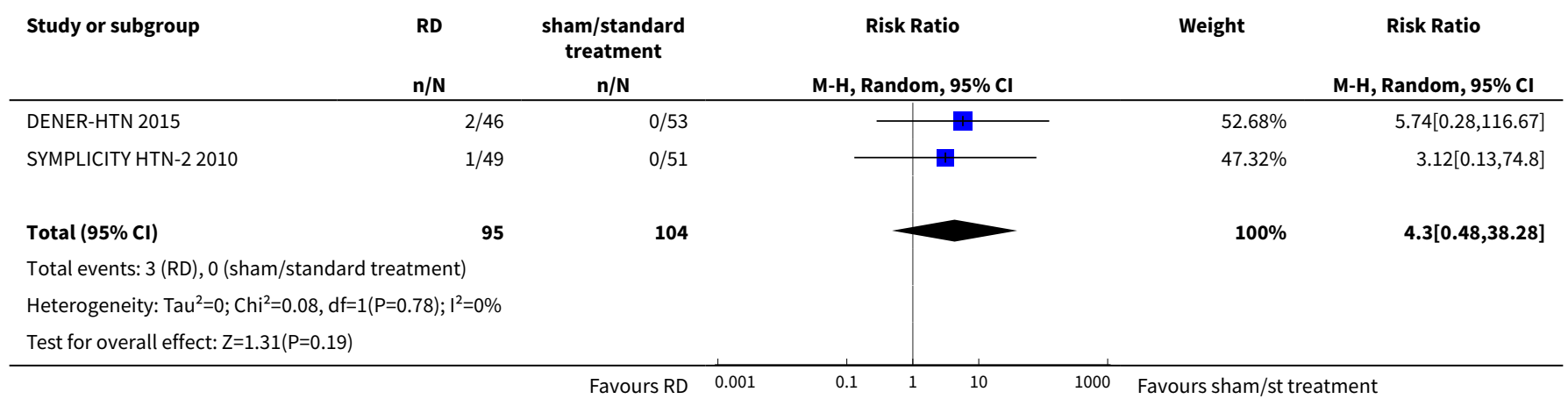

Analysis 1.13. Comparison 1 Renal denervation vs. sham/standard therapy, Outcome 13 hypotensive episodes.

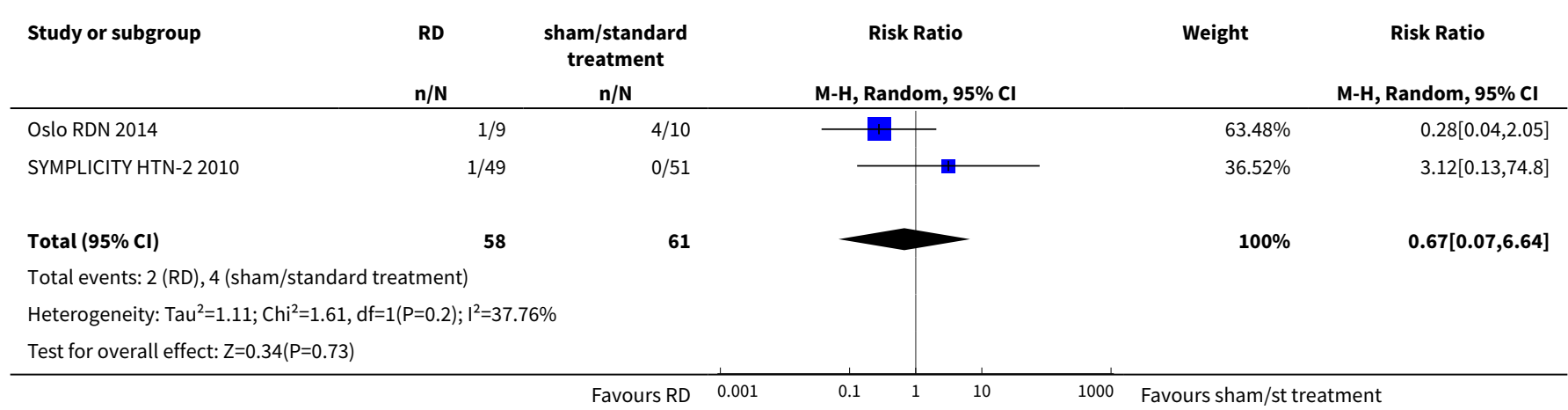

Analysis 1.14. Comparison 1 Renal denervation vs. sham/standard therapy, Outcome 14 hypertensive crisis.

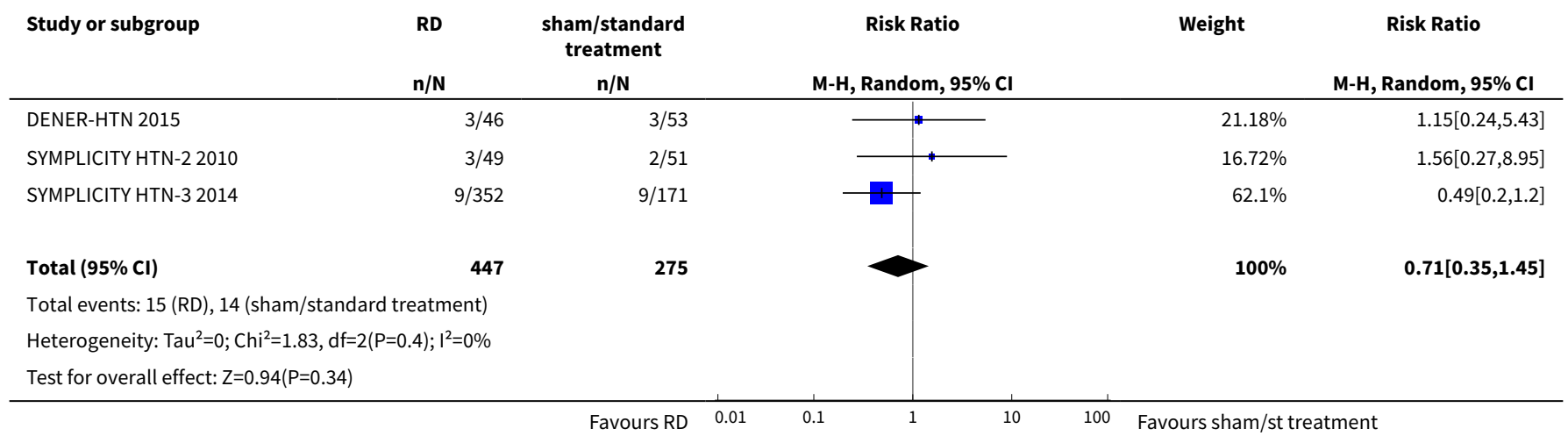


Analysis 1.15. Comparison 1 Renal denervation vs. sham/standard therapy, Outcome 15 hyperkalemia.

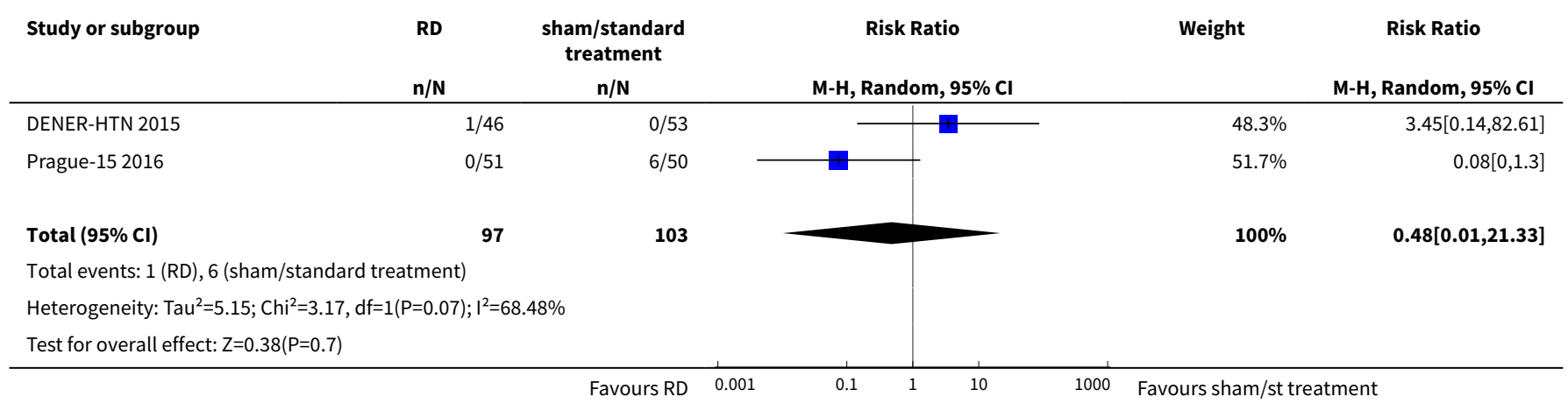

\section{APPENDICES}

\section{Appendix 1. Search strategies}

Database: Ovid MEDLINE(R) 1946 to Present with Daily Update

Search Date: 15 February 2016

1 denervation/ (13728)

2 ((kidney? or renal or transcatheter) adj8 (denervat\$ or sympathectom\$)).mp. (2344)

3 (RDN or RSDN).tw. (184)

4 or/1-3 (15195)

5 hypertension/ (206622)

6 hypertens\$.tw. (322078)

7 exp blood pressure/ (260289)

8 blood pressure.mp. (366575)

9 or/5-8 (619538)

10 randomized controlled trial.pt. (406217)

11 controlled clinical trial.pt. (90055)

12 randomized.ab. (303442)

13 placebo.ab. (155007)

14 drug therapy.fs. (1819658)

15 randomly.ab. (214885)

16 trial.ab. (312775)

17 groups.ab. (1360639)

18 or/10-17 (3449945) 
19 animals/ not (humans/ and animals/) (4154861)

2018 not $19(2937902)$

214 and 9 and 20 (275)

22 remove duplicates from 21 (274)

Database: Cochrane Central Register of Controlled Trials <2016, Issue 2> via Cochrane Register of Studies Online Search Date: 15 February 2016

$\# 1$ denerv ${ }^{\star} 501$

\#2 sympathectom* 208

\#3 \#1 OR \#2 658

\#4 hypertens ${ }^{\star} 37999$

\#5 \#3 AND \#4 176

Database: Embase <1980 to 2016 February 12>

Search Date: 15 February 2016

1 renal denervation/ (2687)

2 ((kidney? or renal or transcatheter) adj8 (denervat\$ or sympathectom\$)).mp. (4141)

3 or/1-2 (4141)

4 exp hypertension/ (542358)

5 hypertens\$.tw. (473931)

6 exp blood pressure/ (432181)

7 (blood pressure or bloodpressure).mp. (471761)

8 or/4-7 (1019811)

9 randomized controlled trial/ (392471)

10 controlled clinical trial/ (391924)

11 crossover procedure/ (46039)

12 double-blind procedure/ (126084)

13 (randomi?ed or randomly).tw. (841320)

14 (crossover\$ or cross-over\$).tw. (77898)

15 placebo.ab. (218800)

16 (doubl\$ adj blind\$).tw. (158837)

17 assign\$.ab. (270222) 
18 allocat\$.ab. (96961)

19 or/9-18 (1369620)

20 (exp animal/ or animal.hw. or nonhuman/) not (exp human/ or human cell/ or (human or humans).ti.) (5431415)

2119 not $20(1206052)$

223 and 8 and 21 (347)

23 remove duplicates from 22 (331)

Database: Hypertension Group Specialised Register

Search Date: 16 February 2016

\#1 denerva*

\#2 sympathectom*

\#3 \#1 OR \#2

\#4 (CCT OR RCT):DE

\#5 (Review OR Meta-Analysis):MISC2

\#6 \#4 OR \#5

\#7 \#3 AND \#6

Database: ClinicalTrials.gov

Search Date: 15 February 2016

Study type: Interventional Studies

Conditions: hypertension

Interventions: denervation

Outcome Measures: blood pressure

First received: From 03/01/2015 to 02/15/2016 (12)

Database: WHO International Clinical Trials Registry Platform

Search Date: 15 February 2016

hypertension AND denervation (139)

Database: PubMed

Search Date: 16 February 2016

((denervation OR sympathectom* OR RDN or RSDN) AND (hypertens* OR high blood pressure) AND ((randomized controlled trial[pt] OR controlled clinical trial[pt] OR randomized[tiab] OR placebo[tiab] OR drug therapy[sh] OR randomly[tiab] OR trial[tiab] OR groups[tiab] NOT (animals [mh] NOT humans [mh]) NOT MEDLINE[sb]) (67)

\section{CONTRIBUTIONS OF AUTHORS}

1. Drafting the protocol: $\mathrm{GC}, \mathrm{DB}, \mathrm{LR}$

2. Study selection: AP, LR

Renal denervation for resistant hypertension (Review) 
3. Extracting data from studies: AP, LR

4. Entering data into Review Manager: AP, LR

5. Carrying out the analysis: DB, AP

6. Interpreting the analysis: $D B, A P, G C$

7. Drafting the final review: $D B, G C, A P, L R$

8. Resolution of disagreements: $D B$

9. Updating the review: DB, LR, AP, GC

\section{DECLARATIONSOF INTEREST}

DB: in 2012, received an Honorary Fellowship from the Cochrane Renal Group as Fellow of the European Renal Best Practice (ERBP) group. AP: None known.

GC: None known.

LR: None known.

\section{SOURCES OF SUPPORT}

\section{Internal sources}

- Department of Medical and Surgical Sciences, Nephrology and Dialysis Unit, University 'Magna Graecia', Catanzaro, Italy.

- Institute of Clinical Physiology, CNR - Italian National Council of Research, Reggio Calabria, Italy.

\section{External sources}

- No sources of support supplied

\section{DIFFERENCES BETWEEN PROTOCOL AND REVIEW}

Authors order and contribution was updated after finalizing the last revision of the review to best reflect individual contributions to this new version.

\section{INDEX TERMS}

\section{Medical Subject Headings (MeSH)}

Angina, Unstable [etiology]; Antihypertensive Agents [therapeutic use]; Blood Pressure Determination; Drug Resistance; Hypertension [*therapy]; Kidney [ ${ }^{\star}$ innervation]; Myocardial Infarction [etiology]; Stroke [etiology]; Sympathectomy [adverse effects] [ ${ }^{\star}$ methods]

\section{MeSH check words}

Humans 